
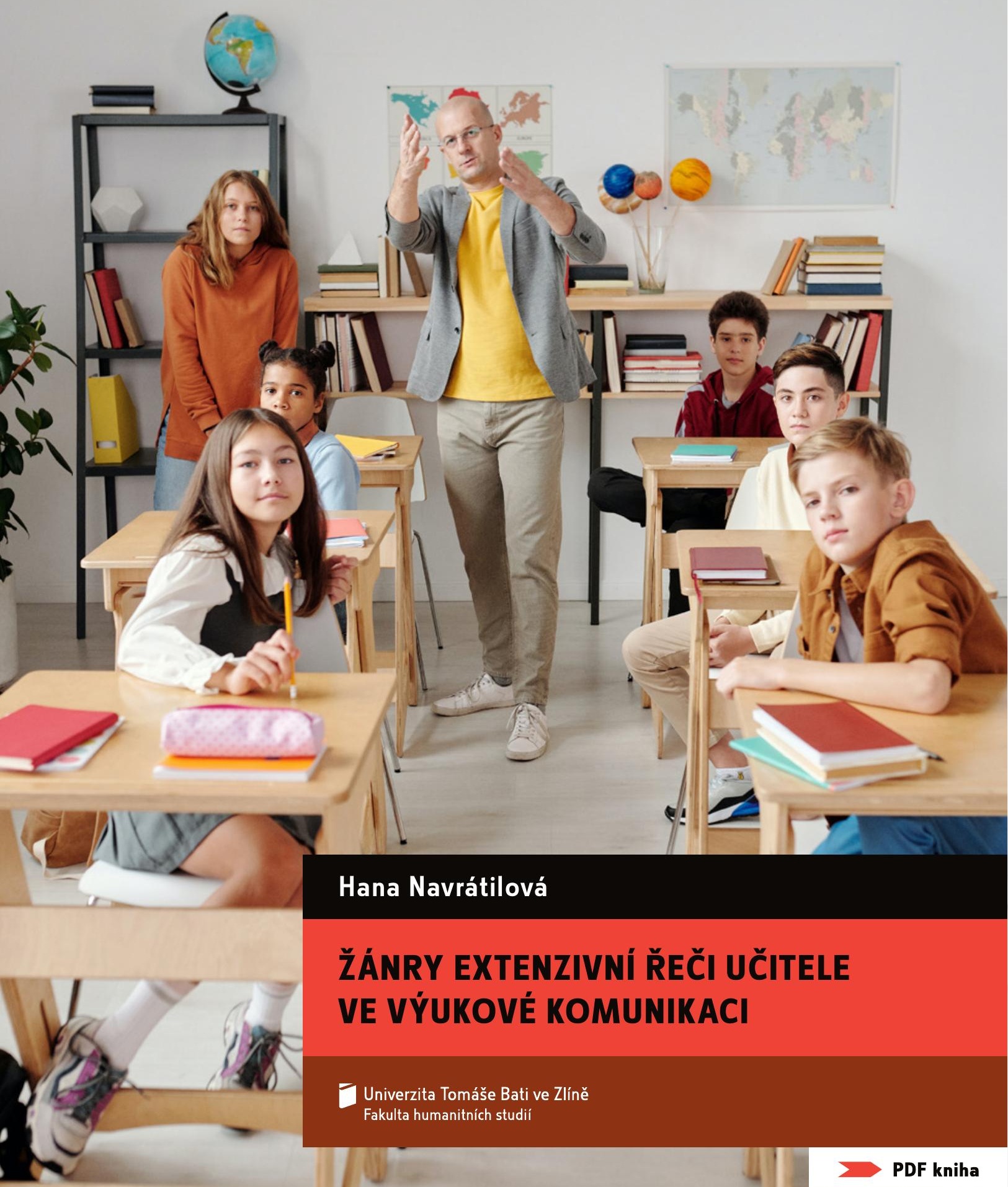

\title{
ŽÁNRY EXTENZIVNÍ ŘEČI UČITELE VE VÝUKOVÉ KOMUNIKACI
}

Univerzita Tomáše Bati ve Zlíně
Fakulta humanitnich studií 

Univerzita Tomáše Bati
Fakulta humanitních studií 

Hana Navrátilová

\section{ŽÁNRY EXTENZIVNÍ ŘEČI UČITELE VE VÝUKOVÉ KOMUNIKACI}

Univerzita Tomáše Bati

Fakulta humanitních studií 
KATALOGIZACE V KNIZE - NÁRODNÍ KNIHOVNA ČR

Navrátilová, Hana

Žánry extenzivní řeči učitele ve výukové komunikaci / Hana Navrátilová. -- Pořadí vydání: první, vydáno elektronicky. -- Ve Zlíně : Univerzita Tomáše Bati, Fakulta humanitních studií, 2021. -- 1 online zdroj. -- (Pedagogika)

České a anglické resumé

Obsahuje bibliografii

ISBN 978-80-7678-052-1 (online ; pdf)

*37.064.2* 37.091.33-021.364*316.772.4:37*37.012*373.3* (437.3) * (048.8)

- učitel a žák

- dialogické vyučování

- pedagogická komunikace

- pedagogický výzkum -- Česko

- základní školy -- Česko

- monografie

37 - Výchova a vzdělávání [22]

(C) PhDr. Hana Navrátilová, Ph.D.

Recenzovali:

prof. PhDr. Hana Lukášová, CSc.

doc. PhDr. Tomáš Svatoš, Ph.D.

(C) Univerzita Tomáše Bati ve Zlíně, 2021

FAKULTA HUMANITNICH STUDIÍ / EDICE PEDAGOGIKA

ISBN 978-80-7678-052-1 


\section{OBSAH}

ÚVOD

1/ EXTENZIVITA V JAZYCE A ŘEČI

$\begin{array}{ll}1.1 & \text { Extenzivita ve výukové komunikaci } \\ \end{array}$

2/ ŘEČ UČITELE

2.1 Řeč a komunikace podporující učení žáků 26

2.1.1 Otázky učitele 28

2.1.2 Od lešení k dialogickému vyučování 31

2.2 Verbální moc učitele 33

3/ ŽÁNRY VÝUKOVÉ KOMUNIKACE

4/ SOUČASNÉ VÝZVY VÝZKUMU VÝUKOVÉ KOMUNIKACE 47

5/ VÝZKUM EXTENZIVNÍCH PROMLUV UČITELE NA 2. STUPNI ZŠ 51

5.1 Design výzkumu 53

5.2 Výzkumný vzorek 55

5.3 Fáze a metody sběru dat $\quad 59$

5.3.1 Nepřímé pozorování $\quad 59$

5.3.2 Zúčastněné pozorování $\quad 59$ 
5.3.3 Př́ítomnost výzkumníka v terénu 60

5.3.4 Nestrukturované rozhovory s učiteli 61

5.4 Analýza dat 62

5.5 Kvalita výzkumu $\quad 64$

5.6 Etika výzkumu $\quad 65$

6/ PO STOPÁCH ŽÁNRŮ V EXTENZIVNÍ ŘEČI UČITELE

6.1 Vymezení extenzivní promluvy v řeči učitele 67

6.2 Žánry extenzivních promluv $\quad 71$

7/ EXPOZIČNÍ ŽÁNR

$\begin{array}{ll}7.1 \text { Učitelova práce s pojmy v expozičních promluvách } & 78\end{array}$

$\begin{array}{ll}7.2 \text { Strategie učitele v expozičním žánru } & 79\end{array}$

7.2.1 Přepínání registru promluvy $\quad 80$

$\begin{array}{ll}\text { 7.2.2 Interakční prvky promluvy } & 81\end{array}$

7.2.3 Učitelovy verbální přešlapy 87

$\begin{array}{ll}7.3 \text { Proklamace významu obsahu promluvy } & 90\end{array}$

$\begin{array}{lll}\text { 7.3.1 Upevnění významu promluv } & 90\end{array}$

7.3.2 Popření významu promluvy 93

7.4 Reaktivita v promluvách expozičního žánru 95

7.4.1 Extenzivní promluvy v reakci na žáka 96

7.4.2 Od reakce na žáka k vlastní asociaci 108

7.4.3 Vyvolání reakce žáka 111

$\begin{array}{lll}7.4 .4 & \text { Nulová reaktivita } & 115\end{array}$

8/ ŽÁNRY NA OKRAJI

$\begin{array}{ll}8.1 \text { Instrukční žánr } & 117\end{array}$

8.1.1 Instrukční vata 120

8.1.2 Jazyk instrukce 122

8.2 Evaluační žánr 125 
8.3 Apelativní žánr 129

8.4 Reaktivita ve vztahu k okrajovým žánrům 131

9/ JAK SE PROJEVUJE EXTENZIVITA V ŽÁNRECH PROMLUV UČITELE? 135

10/ DISKUZE

10.1 Limity výzkumu 141

ZÁVĚR

SEZNAM POUŽITÝCH ZDROJŮ

$\begin{array}{ll}\text { RESUMÉ } & 153\end{array}$

$\begin{array}{ll}\text { SUMMARY } & 155\end{array}$

Tab. 1 Přehledová tabulka pozorování u jednotlivých učitelů 58

Tab. 2 Přehled žánrů extenzivních promluv učitele patřících k expozičnímu žánru $\quad 75$

Tab. 3 Přehled žánrů extenzivních promluv učitele patřících k instrukčnímu žánru 118

Tab. 4 Přehled žánrů extenzivních promluv učitele patřících k evaluačnímu žánru 126

Tab. 5 Přehled žánrů extenzivních promluv učitele patřících k apelativnímu žánru

Tab. 6 Reaktivita promluv se vstupem žáka do komunikace v jednotlivých žánrech 



\section{ÚVOD}

Zájem výzkumníka o komunikaci probíhající ve školní třídě může být v současnosti nasměrován dvěma proudy. Snaží se bud' odhalit aktuální proměny komunikace, jak je ovlivňuje kupříkladu využití technologií, nebo hledá odpovědi na otázky týkající se neodhalených míst v dosavadních poznatcích. Tato kniha je odrazem druhého uvedeného případu. Jejím cílem je nahlédnout „pod pokličku“ komunikace mezi učitelem a žákem ve trrídě se zaměřením na aspekt řeči učitele, jaký nebyl prozatím zcela prozkoumaný, a zodpovědět otázky, které se vážou konkrétně k extenzivitě promluv učitele.

Vstoupit na pole výzkumu komunikace ve školní třídě není jednoduché rozhodnutí. Můžeme konstatovat, že studie badatelů jednotlivců i celých výzkumných týmů v oblasti výukové komunikace patří k tradicím českého i zahraničního pedagogického výzkumu. Po „boomu“ zkoumání různých aspektů této komunikace v 70. letech $v$ zahraničí a o dvacet let později také v českém prostředí se může zdát, že většina podstatných aspektů této komunikace byla již objevena i přezkoumána. Výzkumy interakce a komunikace ve výuce se zaměřují na různé oblasti, badatelé tak mají dnes širokou představu o tom, jak probíhají interakce mezi učitelem a žáky, jaké formy a funkce nacházíme v komunikaci ve třídě a jaký je jejich vliv na žákovo učení (Mercer \& Dawes, 2014). Přehled o vývoji výzkumů v českém prostředí včetně odkazů na vliv zahraničních prací i náměty k diskuzi získáváme ve studiích Mareše (2009) nebo Janíkové (2009). Podle Mareše (s. 14) nastal po roce 1989 rozvoj výzkumu směrem k rozšíření zájmu o procesuální proměnné, tedy průběh dění ve tř́dě se snahou zachytit skutečnou podobu komunikace a zahrnující také komunikaci mezi žáky navzájem namísto tradičního pohledu na přenosy mezi učitelem a žákem. Zároveň se dalším výzkumným polem staly proměnné kontextové jako klima třídy či kultura školy. V posledních dekádách pak 
významný posun v českém i mezinárodním měřítku souvisí s příchodem diskuzí nad učením a vyučováním reflektující zájem o kognitivní a lingvistické procesy výukové komunikace (Applebee, Langer, Nystrand \& Gamoran, 2003).

Současná komunikace ve školní třídě pohledem výzkumu autorského kolektivu Šed'ová, Švaříček a Šalamounová (2012) se vyznačuje stabilitou struktury IRF (iniciace učitele - odpověd’ žáka - zpětná vazba učitele), přičemž žáci se do komunikace zapojují především organizačně laděnými otázkami a komunikace zůstává ovlivněna silnou dominancí učitele. Struktura IRF je hodnocena převážně jako defektní struktura diskurzu, která ovlivňuje odolnost komunikace nastavené jako převážně neinteraktivní (Lyle, 2008). Tato zjištění přitom pokrývají zahraniční výzkumy komunikace ve třídě již od 70 . let, kdy se opakuje kvantitativně potvrzovaná nerovnováha v množství příspěvků do komunikace ze strany učitele a žáků, chybějící reciprocita výměn a nerovnováha také v kontrole komunikace a mocenských vztazích (Burns \& Myhill, 2004). Učitelé jsou tak již řadu let podrobováni kritice, př́ípadně mohou prostřednictvím akčního výzkumu svou komunikaci se žáky zlepšovat a uplatňovat principy dialogického učení.

Učitel ve vzájemné komunikaci se žáky v prostředí školní třídy je rovněž ústřední postavou této knihy. Zaměřuji se přitom na jeho verbální řeč, zajímají mě promluvy, které charakterizuji jako extenzivní, zkoumám jejich žánry. Extenzivita učitelových promluv je tématem, jakému se prozatím český ani zahraniční výzkum zcela nevěnoval. Typický je zájem o dílčí, obvykle kvantifikovatelné aspekty rozsahu řeči učitele, celkově se pak výzkum orientuje na extenzivitu v řeči žáků jako cílový, žádoucí jev ukazující na proměnu rozložení komunikace směrem k aktivitě žáků.

Extenzivita v současných teoriích jazyka a komunikace byla zásadním, přesto však tvrdým oříškem k rozlousknutí, a věnuji se jí proto v první kapitole. Představuji koncept extenzivity z pohledu pedagogiky a dalších vědních disciplín, podnětným zdrojem se stala lingvistika, především poznatky stylistiky. Uvažuji nad extenzivitou jako dimenzí řeči, která na základě teorie binárních opozic může být př́iznaková, či nikoliv. Extenzivní promluvy učitele lze takto posuzovat jako nepříznakové z hlediska žádoucnosti, na příkladu jiných binárních jevů se snažím tento přístup dále osvětlit. Základní koncept extenzivity $v$ jazyce a řeči doplňuji dále o poznatky studií zaměřených př́mo už na výukovou komunikaci, kde je extenzivita pojímána konkrétním, avšak jen dílčím způsobem.

Komunikace probíhající převážně mezi učitelem a žáky je vnímána jako centrální aspekt procesu vyučování (McCroskey \& Richmond, 1982) a bázový prostředek pro dosahování stanovených výukových cílů (Janíková, 2011, s. 45), základním nástrojem pro kognitivní rozvoj žáka (Šed'ová \& Švaříček, 2010; Šed'ová, Sedláček, Švaříček, Majcík, Navrátilová, Drexlerová, Kychler \& Šalamounová, 2019). Na základě 
současných výzkumných zjištění tak vysvětluji zásadní roli řeči učitele pro podporu učení žáka. Výzkumy se zaměřují na stav a podporu dialogu ve školní tř́iě, s pohledy na význam otázky a zpětné vazby učitele pod pokličkou reaktivity, tedy provázanosti jednotlivých promluv. Silnou bariérou v tomto procesu jsou však projevy moci učitele, ve vztahu k tématu diskutuji především učitelem verbalizovanou moc. Uvažuji tak nad vztahem mezi extenzivitou promluv v konkrétních žánrech a projevy kontroly a moci v podobě verbálních přešlapů.

Učitelovy extenzivní promluvy mají identifikovatelnou funkci (případně funkce), jež může určit jejich zasazení do konkrétního žánru. Třetí kapitola obsahuje tedy sumarizaci poznatků týkajících se existujících pojetí žánrů výukové komunikace, přičemž pro vymezení samotného pojmu žánr jsem opět čerpala také z příspěvků lingvistických studií (Mistrík, 1975; Auer, 2014). Cíleně se přitom zaměřuji především na žánry, jejichž typologie či charakter vytváří dostatečný opěrný bod pro následné vlastní zkoumání žánrů extenzivních promluv učitele.

Zatímco cílem doposud popsaných kapitol bylo vymezit stěžejní koncepty a pojmy, čtvrtá kapitola uzavírá teoretický vstup propojením zkoumané extenzivity promluv učitele s aktuálními výzvami českých i zahraničních odborníků ve studiu výukové komunikace. Ve shodě s Marešem (2009) či Mercer \& Dawes (2014) se přikláním k čerpání poznatků z disciplín, které mohou obohatit pohled pedagogiky na řeč učitele, $\mathrm{z}$ nichž se pochopitelně nabízí především lingvistika.

Výzva, která byla akcentována v dřívějších letech, a mnohé současné studie ji naplňují, se týkala zkoumání reálných situací a vedla ke snaze zachytit skutečně probíhající výměny, i když je v případě přítomnosti výzkumníka ve třídě je vždy potřeba zohlednit otázku ovlivnění komunikačního chování na straně učitele i žáků (Švaříček, 2011). V tomto textu jsou rovněž stěžejní data, v nichž lze sledovat konkrétní komunikační situace ve třídě a prostřednictvím jejich záznamu se k nim opakovaně i vracet. Cílem výzkumu představeného v tomto textu je zjistit, jak fungují žánry extenzivních promluv učitele ve výukové komunikaci. Zkoumání extenzivních promluv učitele jako vybraných segmentů řeči učitele a naplnění stanoveného cíle se neobejde bez vymezení takových promluv ještě před procesem analýzy datového materiálu. Exkurz v 7. kapitole se tedy týká charakteristik extenzivních promluv učitele na základě kritérií, k nimž patří forma, rozsah či informační bohatost promluvy.

V následujících kapitolách se snažím provést čtenáře na cestě tvořené mými výzkumnými zjištěními. Začínám identifikovanými nejvýznamnějšími žánry extenzivních promluv, snažím se odkrýt, jak učitelé s těmito žánry pracují, jak jimi prostupuje také verbální kontrola učitele nad tř́́dou. Zkoumání těchto extenzivních promluv učitele jako samostatných segmentů následně rozšiřuji o pohled na reaktivitu, tedy propojení těchto promluv s promluvami žákovskými. Zajímá mě, 
zda a jak extenzivní promluvy reaktivitu umožňují. Žánry promluv s vnímáním jejich kontextu v podobě reaktivity promluv tvoří tak rámec pro zodpovězení hlavní výzkumné otázky v závěru.

Cesta např́č výzkumnými zjištěními má sice svůj konec, ten však může zůstat pootevřený prostřednictvím otázek, které se stále vynořují, na jaké by odpověděl další, jiný výzkum. Knihu proto uzavírá diskuze týkající se nejen daných zjištění, ale i celého procesu její tvorby. 


\section{$1 /$ \\ EXTENZIVITA V JAZYCE A ŘEČI}

Extenzivita je v tomto textu nahlížena jako jedna z dimenzí verbálních promluv ve výukové komunikaci. Pojem extenzivity není v odborné literatuře vymezen takovým způsobem, aby bylo možné prodiskutovat jednotlivé autorské definice. Pro uchopení extenzivity tak bylo nezbytné čerpat z několika souvisejících konceptů, jejichž prostřednictvím sledujeme charakter řečové komunikace tak, aby nabídly možný pohled na extenzivní řeč a promluvu jako její segment. $\mathrm{V}$ závěru kapitoly představuji vlastní vymezení extenzivní promluvy, které vychází z popsaných konceptů pojetí rozsahu, příznakovosti a blízkého pojmu „extended talk“ ze zahraničních zdrojů zabývajících se výukovou komunikací. Takto nastavené pojetí se stalo následně výchozím bodem pro zkoumání extenzivních promluv učitele ve vyučování.

Zvolený koncept extenzivity v jazyce a řeči nečerpá výhradně z poznatků jediné disciplíny, ale těží z výsledků pedagogiky, lingvistiky včetně aplikovaných disciplín, a rovněž se dotýká vymezení extenzivity v př́rodních vědách, kde je tento pojem spojený se základními jevy a zákonitostmi a dále byl aplikován a rozvíjen i v kontextu společenských věd. Dochází tak k naplnění potřeby komplexnosti nazírání na jevy a procesy edukační reality (Průcha, 2002, s. 127). Koncept extenzivity jsem v této kapitole zasadila do širšího rámce poznatků různých vědních disciplín, následně je extenzivita diskutována v konkrétních pohledech pedagogiky a výukové komunikace na tento jev.

Pokud výzkumník v multidisciplinárním pojetí vychází z poznatků vybraných disciplín, zaměřuje se na to, jak „vybudovat mosty“ napříc těmito poznatky s cílem vytvořit živější obraz zvoleného tématu či problému ve specifické situaci, než jaký by byl možný s využitím jediné disciplíny (Hornberger \& Hult, 2006 in Šebesta, 2016). Přes specifičnost výukové komunikace, která se v různých aspektech liší 
od běžné interpersonální komunikace vzhledem k jejím cílům a funkcím, je bezpochyby žádoucí, aby výzkum komunikace ve vyučování čerpal nejen z poznatků pedagogických disciplín. Jedná se totiž o interdisciplinární výzkumné pole, které předpokládá široké spektrum teoretických východisek, výzkumných otázek i metodologických postupů (Tůma, 2014, s. 179). Mezi zásadní disciplíny, v nichž lze hledat inspiraci a průnik teoretických tezí i podporu pro výzkumná zjištění, patří pro tuto oblast lingvistika. Přesto „stranou pozornosti dosud zůstávají podněty ke studiu komunikačních procesů a textu, které nabízejí některé současné práce českých a slovenských pedagogů. ... za plodný považujeme reciproční postup, nebot' i lingvistika má pro řešení některých pedagogických úkolů co nabídnout.“ (Šlédrová, 1992, s. 129). Proměny v bádání lingvistů směrem ke komunikačně orientovanému zkoumání řeči a jazyka a akcentaci funkcí jazyka přinášejí užitečná zjištění ze zachycených komunikačních situací také v prostředí školy a tř́́dy (Höflerová, 2003).

Pro koncept extenzivity jsem čerpala z inspirativních poznatků stylistiky. Verbální promluvy jako komplexní jednotky řeči se vyznačují vlastnostmi, k nimž patří koherence, informativnost, organizovanost, propojení s daným kontextem užití promluvy mluvčím a lze je rozlišit i na základě rozsahu. Při pohledu na texty psané řeči je vždy patrný kvantitativní rozdíl mezi jednotlivými žánrovými útvary, přičemž rozsah by měl být vždy přizpůsoben tématu a funkci projevu. Rozsah či rozpětí je tak jen jednou z dimenzí textu jak v psané, tak mluvené formě. Extenzita odkazující na tuto dimenzi je případem kvalifikátoru pro určení žánru textu, nejedná se však o dimenzi vyjádřenou zjednodušeně jen počtem slov. Rozsah vymezený počtem slov nabývá rozdílného významu pro žánry patřící k zastřešujícímu komunikačnímu stylu, kdy je nutné posuzovat různý rozsah jako dostatečný. Př́kladem textu naučného stylu je dizertace nebo recenze. Oba žánry jsou zařazeny do tzv. rozsáhlých žánrových útvarů, přesto se výrazně liší adekvátním počtem slov vzhledem ke stylu a dalším kvalifikátorům textu (Mistrík, 1975).

Dimenzionalita textu se vztahuje k dalšímu konceptu, o který se opírám. Pro analýzu dimenzionality textu se využívá vyhledání př́iznaku, který umožní analýzu zaměřit a specifikovat tak charakteristiku zvolené dimenze. Teorie příznakovosti je postavena na konceptu binárních opozic. Dva znaky se mohou vztahovat $\mathrm{k}$ téže předmětné skutečnosti, význam jednoho znaku však fixuje určitý příznak této skutečnosti, zatímco význam druhého znaku se tohoto příznaku nedotýká. V lingvistice jsou takto analyzovány kupříkladu dvojice, kdy maskulinní tvary slov jsou bezpříznakové a femininní považovány za příznakové, poněvadž příznakem je ženskost. Ženský tvar slova tak jednoznačně označuje př́slušnost k ženě, ovšem mužský rod jako bezpř́íznakový může patřit k oběma variantám (Chromý, 2008, s. 197). Na tomto principu je aplikováno užívání mužských tvarů pro profese - výraz 
„učitel“ tak označuje muže i ženu v učitelské profesi v případech, kdy není příznak podstatný pro jejich rozlišení. V současných lingvistických studiích se autoři kromě genderu věnují expresivní či emocionální prríznakovosti jazyka a řeči, často ve vazbě na konkrétní žánr (Hradilová, 2015).

Koncept příznakovosti je $\mathrm{v}$ odborných textech zastoupen $\mathrm{v}$ několika rolích. Může sloužit jako objasňující teoretický koncept i nad rámec lingvistických disciplín, vymaňuje se pouze ze vztahu k jazykovým pravidlům, dotýká se obecně preferencí v jazyce a řeči. Příznakovost je pojímána rovněž jako univerzální součást lidských projevů, čímž se nabízí využití konceptu v dalších vědních oborech (Haspelmath, 2006). Př́znakovost v řeči byla předmětem bádání Pražské lingvistické školy. Autoři se dodnes opírají o Jakobsonovo vymezení, které je dále aplikováno i v širším pojetí v sociálních vědách. Sociologie pak studuje příznakové jevy kultury a sociálního života ve vztahu k příznakovým ve smyslu sociálně marginálních. Také zde jsou diskutovány průniky příznakovosti (Brekhus, 1998). Základní složkou příznakovosti je obsah a informační hodnota. Ačkoliv se původní Jacobsonova teorie rozvinula v lingvistickém zkoumání nad rámec opozic, z jeho konceptu vycházejí teorie kategorizace příznakovosti v sociálních vědách zahrnující různorodé opozice jako svoboda/otroctví, muž/žena nebo mluvená/psaná řeč (Batistella, 1990).

Za bezpříznakové jsou obvykle považovány paradigmatické jevy s centrálním postavením $v$ daném systému, frekventovaným výskytem a nacházející se v celém spektru komunikace. Proti nim bývají na opačném pólu postaveny jevy okrajové, periferní, nepravidelné, vybočující některými svými vlastnostmi z předpokládaného paradigmatu, jevy některou svou vlastností anomální, tedy jevy příznakové (Čechová, 2005, s. 9). Běžné jevy v komunikaci jsou tedy hodnoceny jako bezpř́iznakové. S konceptem pracuje $v$ lingvistice nejčastěji fonologie a stylistika, kdy základní opozice tvoří jazykové prostředky slohově příznakové a bezpříznakové.

Prosté chápání příznakovosti jako jednoznačně stanovených opozic se však postupně formovalo v jiné, rozvitější koncepty. Autoři textů z lingvistiky či edukační lingvistiky identifikovali dynamičnost prríznakovosti a bezpříznakovosti. Mezi jevy dochází ke vzájemným posunům včetně možnosti výskytu přechodného pásma. Svobodová (2000, s. 88) tak v analýze školské komunikace poukazuje na jazykové jevy v řeči žáků, které škola odmítá jako nevhodné. Stejné jevy jsou však v jazyce mimo školu už zcela běžné, bezpříznakové, neutrální, zatímco to, co škola pokládá za běžné, směřuje často už k vyššímu stylu, jaký může být slohově až silně př́íznakový. Pro příznakovost jako méně očekávaný jev platí, že obsahuje v dané situaci určitý prvek navíc. Zároveň je však závislá na kontextu jazyka a komunikace. Teorie binárních opozic je tak rozšířena o pohled na vztah příznakovost - nepříznakovost v podobě škály, na níž příznak zesiluje či zeslabuje, př́ípadně mohou dokonce vznikat hierarchie prvků př́znakovosti (Greenberg, 2005). 
Teorie příznakovosti se dotýká také aspektu nadměrnosti informací v řeči z hlediska kognitivní náročnosti sdělení, odráží tak orientaci badatelů na kognitivní dimenzi jazyka a řeči. Haspelmath (2006) shrnuje významy, jakých může nabývat příznakovost, do několika kategorií. Patří k nim příznakovost jako komplexita, abnormalita, frekvence užití či náročnost bud' v jazykových rovinách, nebo koncepčně pojímaná jako kognitivní náročnost. Kognitivní teorie příznakovosti se zaměřuje na percepci verbálních projevů učícím se subjektem. Příznakové jevy, verbální projevy, jsou kognitivně komplexnější z hlediska požadavku na pozornost recipienta, mentální úsilí a čas nutný ke zpracování projevu (Givon, 1991 in Haspelmath, 2006). Ve spojení s extenzivitou můžeme tak konstatovat, že extenzivní verbální projev je komplexnější a tím také náročnější na produkci i porozumění než krátké verbální projevy.

Verbální promluvy učitele ve vyučování patří obvykle k částečně připraveným projevům, což znamená, že učitel uvažuje předem nad tématem, vysvětlením základních pojmů, strukturou výkladu, vysvětlením či instrukcí pro plánované činnosti. Zásadní roli hraje snaha upořádat sdělované informace podle závažnosti, což umožňuje autorovi/mluvčímu dosáhnout co největšího kontextového efektu a zároveň umožňuje adresátovi, aby mohl na interpretaci vynaložit co nejmenší kognitivní úsilí (Hoffmannová et al., 2016). Neznamená to ovšem, že by žák v procesu recepce sdělení neměl rozvíjet své myšlení. Nadměrné množství sdělovaných informací, tedy informační bohatost $v$ jediné promluvě však může fungovat kontraproduktivně.

Kvantitativní lingvistika věnuje pozornost možnostem měření koncentrovanosti textu vzhledem k použitému lexiku, tedy slovní bohatosti textů (Čech \& Kubát, 2017). Proces porozumění textům jak v psané či mluvené formě má však několik rovin zahrnujících i porozumění celkovému významu jednotek textu a rozpoznání nových informací. Učitelem komunikovaný obsah v promluvě lze vnímat z hlediska jednotlivých informačních jednotek, tedy oddělitelných segmentů v promluvě, které př́ijemcům přinášejí novou informaci. Každá informace má svou hodnotu, avšak hodnota informace je determinována schopností ji efektivně komunikovat (Sluková, 2007). Extenzivní promluva je sycená větším množstvím informačních jednotek, což vytváří kontrast k ostatním promluvám učitele, které za extenzivní nepovažujeme. Větší nasycenost promluvy informačními jednotkami zároveň však nemusí korelovat s vyšším počtem slov v promluvě, jak bychom mohli předpokládat. Naopak se v prezentovaném datovém materiálu ukazuje, že i méně rozsáhlé extenzivní promluvy mohou být až přesyceny sdělovanými informacemi. Konkrétní příklady ilustrující varianty promluv z hlediska informační bohatosti jsou uvedeny dále v kapitole 7.

Extenzivita v kontextu nadměrného množství informací, kterou musí komunikátor produkovat a recipient následně přijmout, je diskutována i v odborných 
textech $\mathrm{z}$ teorie informace. Extenzivita je přitom $\mathrm{v}$ přírodních vědách vnímána natolik jako základní pojem, že se autoři studií z teorie informace, teorie pravděpodobnosti či fyziky nevěnují do hloubky jejímu definování. Extenzivita patří k primárním vlastnostem termodynamických systémů. Její princip si lze představit na příkladu malého kamínku svrženého z kopce. Ten je z počátku nositelem malého množství energie, postupně však na sebe nabaluje další kameny a předměty a energie přenosu tak narůstá. $V$ informační termodynamice se jedná o vlastnost, která je závislá na aktuálním systému, a je tak spojena s proměnnou, jež se týká pravděpodobnosti možných stavů daného systému a vytváří základ pro celý koncept uspořádanosti systému, tedy entropií (Hejna, 2010). Entropie vyjadřuje neuspořádanost či neurčitost systému, která klesá s narůstající informací. Pojem entropie jako míra neuspořádanosti systému překročil čistě přírodovědné uplatnění a našel využití i v sociálních vědách. Ve vztahu k entropii vnímané obecně jako chaos, sociální entropie poukazuje na úpadek určité sociální struktury. Pokud bychom hovořili o nízké entropii komunikační situace, znamenalo by to, že v komunikaci převládá chaos spojený s nedostatečnou mírou informací. Procesuální entropie jako základ Shannon-Weaverova komunikačního modelu řeší především proces přenosu informací. Tento matematický model byl převratným vstupem do teorie informací, ovšem později mu autoři vytýkali především chybějící podstatný prvek, a to zpětnou vazbu probíhající komunikace. Ve vztahu k extenzivitě je významné tvrzení Shannona a Weavera, že efektivní komunikace nesmí překračovat kapacitu kanálu, tedy množství přenášených informací a zároveň použití kódů informací, jež nezpůsobí problémy s porozuměním sdělení (Shannon, 1948).

Koncepty extenzivity, př́źznakovosti a dimenzionality jsou vzájemně provázány. Extenzivita je př́ípadem dimenze, která může být příznaková, či nepříznaková, a to z hlediska žádoucnosti. Příznaková je extenzivita u žáků jako žádoucí, nepříznaková u učitele jako nežádoucí. Žádoucnost je v tomto případě nazírána ve vztahu k př́íjemci extenzivní řeči, kterým je žák či skupina žáků ve tř́́dě. Př́íznakovost pohledem žádoucího stavu lze detekovat také ve vymezení možných binárních jevů ve vztahu ke kvalitě výukové komunikace:

- Struktura komunikace může být flexibilní (příznaková), či neflexibilní;

- rozvitost žákovských promluv (příznaková), či jednoduchost žákovských promluv;

- divergentnost žákovských odpovědí na otázku učitele (př́íznaková), či konvergentnost žákovských odpovědí na otázku učitele;

- otevřenost učitelových otázek (příznaková), či uzavřenost učitelových otázek;

- vysoká kognitivní úroveň učitelových otázek (příznaková), či nízká kognitivní úroveň učitelových otázek.

(volně podle Šed'ová et al., 2012, s. 270) 
Žádoucnost extenzivity v promluvách žáků je důvodem, proč se těmto promluvám věnuje výzkumná pozornost $\mathrm{z}$ hlediska cílů výukové komunikace (srov. Alexander, 2008; Thompson, 2008).

\section{1}

\section{Extenzivita ve výukové komunikaci}

V české odborné pedagogické literatuře se rozlišují pojmy pedagogická a výuková komunikace, jejichž shodným prvkem je specifikum zaměření komunikátora i komunikanta na edukační cíle, obvykle tedy zprostředkované učitelem jako formálně i fakticky hlavním mluvčím. Pedagogická komunikace ovšem zahrnuje veškeré výměny účastníků edukačního procesu, které plní pedagogické funkce i mimo prostředí školy. K výchově a vzdělávání dochází totiž i na fotbalovém hřišti, v klubovně domu pro děti a mládež, všude tam spolu mohou komunikovat edukátor s edukantem (Průcha, 2015). Koncept pedagogické komunikace se však i v zahraničním výzkumu zužuje na komunikaci výukovou (instructional communication) či komunikaci ve tř́dě (classroom communication). Jako výzkumné pole nabízí především zaměření na ústřední roli komunikace pro podporu procesu učení a kompetence učitele, kteří o takovou komunikaci usilují, aby se stali skutečnými experty (Simonds \& Cooper, 2014).

V této knize používám pojmy výuková komunikace a komunikace ve (školní) třídě jako ekvivalenty, vždy je tím však míněna komunikace mezi učitelem a žáky v prostředí školní třídy, jejímž cílem je dosažení stanovených edukačních cílů a která probíhá ve vymezeném čase vyučovací jednotky.

Výuková komunikace je součástí lidského komunikačního procesu. Jako specifická komunikace se nachází v kontextu výuky, a to napříč jednotlivými vyučovacími předměty a vzdělávacími stupni. Pozornost je směřována k proměnným komunikace, jež mohou ovlivnit a ovlivňují výukové prostředí, jako je moc učitele, neverbální prostředky, komunikační styl učitele a další (Fassett \& Warren, 2010). Jako výzkumné pole je výuková komunikace zakotvena v pedagogice, pedagogické psychologii a komunikačních studiích (Myers, 2010), přínos k poznání specifik výukové komunikace mají i aktuální lingvistické studie čerpající z reálné podoby komunikace (Höflerová, 2003). Společným předmětem zkoumání zůstává učitel a žák a jejich vzájemná interakce.

Výuková komunikace se uskutečňuje prostřednictvím verbálních i neverbálních prostředků $\mathrm{v}$ jednotlivých promluvách, jež by měly tvořit kompaktní sled komunikačních aktů. Obecně přitom převládá verbalizace komunikačních aktivit, především na straně učitele, zatímco žáci se v reakci na učitelovu promluvu mohou 
omezit na neverbálně vyjádřenou odezvu. Odlišnost charakteristik promluv jedince ovlivňuje každodenní komunikaci učitele v reálné výuce. Schémata střídání výměn promluv mezi učitelem a žákem, způsob započetí sdělení k tématu, použití různorodých jazykových prostředků v řeči, to jsou jen některé příklady takových charakteristik (Rymes, 2009). Pozornost v oblasti vymezení výukové komunikace je dále věnována jejím odlišnostem od běžné mezilidské komunikace mimo školní prostředí. Kromě zmíněných edukačních cílů sem patří specifické funkce jako zprostředkování obsahu vzdělávání, implicitně či explicitně stanovená (a komunikovaná) pravidla mezi účastníky a dílčí odlišnosti, jaké jsou patrné u otázek nebo poskytované zpětné vazby. Specifičnost komunikace ve škole je přitom jeden z cílů zkoumání komunikace. Její pochopení je totiž zásadní i pro didaktické pojetí rolí jednotlivých aktérů výukové komunikace a jejich jednání v komunikaci (Švaříček, 2011, s. 10).

Studie k výukové komunikaci nepracují s rámcovým konceptem extenzivity v řeči, objevuje se v nich ale související pojem tzv. extended talk (tedy extendované řeči) jako jedné z možných podob řeči ve výukové komunikaci. S pojmem „extended talk", tedy extendované řeči, se tak setkáváme v diskuzi odborných textů, které patř́i k zásadním publikacím zahraničních odborníkủ, jako je Neil Mercer nebo Robin Alexander. Týká se vždy mluvené formy jazyka. Vzhledem k tomu, že české odborné zdroje s tímto pojmem zatím nepracovaly, rozhodla jsem se po hledání možných překladů pro termín „extenzivní řeč“. Detailnější vymezení extenzivity pro výzkumné účely je prezentováno dále v kapitole 7.1.

Dostupné zdroje pracující s pojmem extenzivní řeči (extended talk) se zaměřují výhradně na zkoumání tohoto aspektu komunikace na straně žáků. Extenzivní řeč je nahlížena především z hlediska pozitivní transformace výukové komunikace do takové podoby, kdy žáci mají př́ležitost vstupovat s vlastními replikami do probíhající komunikace. Jedním ze základních cílů výukové komunikace je totiž umožnit dítěti být zdatnějším v užití jazyka pro vyjádření myšlenek ve sdílené komunikační situaci (Mercer, 2003). Repliky žáků jsou tak hodnoceny jako dostatečné či nedostatečné z hlediska jejich extenzivity. Jedná se o cílový, příznakový jev, žádoucí stav komunikace na straně žáků jako významných aktérů ve vyučování. Platí zde však i to, co odpovídá konceptu příznakovosti celkově, napříč disciplínami - příznakový jev je v daném kontextu zastoupen spíše okrajově.

Alexander (2008, s. 110) vymezuje rozdíl mezi dialogickou a extenzivní řečí, přičemž uvažuje rovněž o extenzivitě u žákovských replik. Ty mohou přinášet učiteli důležité informace o širším kontextu uvažování žáka. Alexander však posouvá úvahy o extenzivitě žákovských výpovědí směrem k celým sekvencím replik v komunikaci mezi učitelem a žákem. Extenzivní řeč je tak určitým vykročením k dalšímu stupni adekvátní podoby výukové komunikace, a totiž dialogické řeči. 
Vzájemné výměny z výzkumných dat Alexandera (ibid) však obvykle nepřekročí extenzivní řeč tím, že učitelovy repliky na žákovských výpovědích následně nestaví. Provázanost výměn při komunikaci mezi učitelem a žákem byla také podnětem pro zkoumání reaktivity extenzivních promluv učitelů ve sledovaném vzorku.

S odkazem na myšlenky Alexandera přichází také Thompson (2008). Analýzu extenzivních promluv ve výukové komunikaci lze podle Thompsona zasadit do teoretického rámce vycházejícího z prací Bachtina a Lotmana. Opírá se o teze, kdy chápeme text jako prostor, v němž se formy řeči proměšují a interagují. Základní konstrukcí zůstává dialog. Jiné formy řeči, extenzivní formy, mohou mít užitek pro žáky, kteří potřebují rozvíjet schopnost širšího vystavěného argumentu, popisovat, vyprávět, předat ucelenou informaci. Jsou však opomíjeny především proto, že navzdory jejich významu pro rozvoj řeči se v reálné výukové komunikaci téměř nevyskytují. Důvodem je dominance řeči učitele (Brooks, 1989 in Thompson, 2008). Thompson obhajuje ve své práci zahrnutí zkoumání extenzivních promluv v širším dialogu, které mohou být „hnacím motorem“ rozvoje myšlení žáků při sdíleném řešení problému (ibid, s. 243).

Výzkum extenzivních promluv žáků je obvykle svázán se zkoumáním pozorovaných otázek učitele (Nystrand, Wu \& Gamoran, 2001; Boyd \& Rubin, 2006; Thompson, 2008; Soter et al., 2008), které mohou, ale nemusí být jedním z faktorů, jak komunikaci otevř́ít směrem $k$ větší produktivitě délkou i obsahem v promluvě žáka. Dále stejně jako celkově ve výzkumu komunikace ve třídě, i v prŕípadě extenzivní řeči je pozornost věnována specifickým cílům komunikace v přírodovědném vyučování. Významnou roli v koncipování učebních aktivit a struktury komunikace ve třídě hraje přesvědčení učitele. Podpora aktivní a extenzivní řeči žáků je závislá na přesvědčení učitele o tom, že diskuze řízená převážně z jeho strany není ideální pro rozvoj vědecké gramotnosti žáků. Volání po změně v tradičních strukturách výukové komunikace včetně kurikulárních změn, které by takovou změnu usnadnily, nebude úspěšné, pokud učitel sám nebude přesvědčen o významu změny směrem ke smysluplným dialogům o přírodovědných konceptech s aktivním podílem žáků. Nevýhodou je rovněž to, že učitelé jsou i v případě komunikačních zvyklostí ovlivněni vlastními předchozími zkušenostmi v pozici žáka (Pimentel \& McNeill, 2013).

Pátrání po dalších zdrojích, které by nabídly maximum dostupných poznatků k extenzivní řeči ve výukové komunikaci, přineslo výsledek také v podobě textů, kde se vyskytuje přímo pojetí extenzivity v komunikaci učitele, ovšem již jen v dílčí podobě. Pojem extenzivita (extensive talk) se tak objevuje jako jedna z možných popisovaných vlastností řeči učitele, ovšem bez exaktního vymezení nebo záměru zkoumat cíleně extenzivní segmenty učitelovy řeči. Extenzivitu ale můžeme chápat jako zastřešující pojem pro související aspekty řeči učitele, které se již ve 
výzkumech objevují. Jedná se pak obvykle o délku trvání řeči nebo počet slov, která ve výuce učitel pronese. Časté je také jejich porovnávání se stejnými aspekty v řeči žáků. V současnosti se výzkumy odvolávají či přímo opírají o Flandersovo pravidlo dvou třetin, přičemž nálezy se mohou lišit v poměru prostoru pro verbální projev u učitele versus žáka. Dominance učitele ale stále převládá, vyučovací hodiny s opačným jevem existují, nejsou však obvyklé (Šed'ová et al., 2012).

Řada studií poukazuje na negativní vliv nepřiměřeného, nadměrného objemu řeči učitele při výuce. Podle Daviese (2011) by objem času řeči učitele (tzv. TTT = teacher talk time) měl negativně korelovat se stupněm př́ležitostí pro aktivní učení žáků. Jeho výzkum se orientoval na výuku cizích jazyků, kde je aktivní zapojení žáků do komunikace vyjádřené množstvím času jejich řeči žádoucí pro získání specifických komunikačních dovedností v cizím jazyce. Davies ovšem dodává, že méně času, který by tvořila řeč učitele v poměru k žákům, neznamená cíl, jehož bychom měli ve výukové komunikaci dosahovat. Zásadním kritériem musí zůstat kvalita učitelovy řeči ve smyslu efektivnosti obsahu. Promluvy učitele, at' delší či kratší, by měly být jasné, koherentní, přiměřené kognitivní úrovni žáků. Jak konstatuje Ma Xiaou (2006), pokud učitel věnuje rozsáhlé časové úseky vyučovací hodiny vlastnímu vysvětlování nebo organizaci ve formě pokynů, musí být nutně čas ponechaný žákům omezený. Kromě toho je pak méně pravděpodobné, že by žáci sami mohli vložit do komunikace ve třídě vlastní extenzivní promluvy.

Příležitost k verbálním projevům obou aktérů výukové komunikace, učitele a žáků, zkoumal také výzkumný tým autorů kolem T. Janíka. Navázali na videostudie TIMSS realizované na konci 90 . let v Německu a Švýcarsku a prostřednictvím tohoto metodologického postupu se rozhodli zkoumat kurikulum v českých základních školách se zaměřením na jednotlivé oborové didaktiky. Prvním uskutečněným projektem byla videostudie fyziky na druhém stupni základní školy. Výsledkem analýzy 62 vyučovacích hodin bylo konstatování navazující na dřívější práce (Gavora, Průcha aj.), že promluvy učitele v komunikaci dominují a učitel hovoří průměrně pětkrát více než žáci, přičemž v datovém souboru se vyskytovaly i případy, kdy učitelova převaha byla dvacetinásobná (Janík \& Miková, 2006, s. 98). Dominance podílu učitele na promluvách ve třídě byla potvrzena také $v$ jiných výzkumech. Další kolektiv badatelů v českém prostředí (Šed’ová et al., 2012) potvrdil rovněž převahu učitele ve verbálním projevu jak v procentuálně vymezeném podílu na čase vyučovací hodiny, tak i v počtu pronesených slov, který byl výrazně vyšší než průměrný počet slov u všech žáků $v$ dané hodině (ibid, s. 48).

Výsledky výzkumů uvedené v národním kurikulu Velké Británie, mapující období od 80 . let 20. století po rok 2000, ukazují dokonce na zvyšující se proporci řeči učitele na úkor žákovské participace. Naznačují přitom i pohled na kvalitu př́íspěvků učitele, který do své řeči vkládá výroky vytvářející tlak na žáky a bariéru 
pro jejich vlastní iniciace v komunikaci. Procentuálně vyjádřená zjištění objemu řeči učitele ve vyučování rozlišují mezi otázkami učitele (18\%) a ostatními promluvami (67\%). Učitel tedy věnuje značné množství vymezeného času sdělování faktů a myšlenek a předávání instrukcí (Burns \& Myhill, 2004, s. 38).

Část výzkumu zaměřeného na komunikaci začínajících učitelů biologie přinesla zjištění v zajímavém pohledu na problém, s nímž se tito učitelé mohou potýkat, a totiž zprostředkování tématu žákům, s nímž nejsou ještě sami dobře obeznámeni. Zkoumaná data, která Carlsen (1993) nasbíral za rok u 4 učitelů, ukazují, že učitelé měli tendenci mluvit delší časový úsek a s větší frekvencí ve vyučovacích hodinách věnovaných méně známému tématu. Samotné znalosti učitele se tak staly významným zjištěným faktorem ovlivňujícím řeč učitele v jejím rozsahu.

Výzkum řeči učitele se $\mathrm{v}$ posledních letech stále více posunuje od zjišt’ování kvantity k zájmu o sledování kvality řeči. Nestačí tedy jen redukovat nadměrný čas, který tvoří ve výukové komunikaci řeč učitele (Cullen, 1998). Danou charakteristiku extenzivních promluv (ačkoliv těch, které produkují žáci) zachytil také Thompson během realizovaných rozhovorů s učiteli, jenž uvažoval nad extenzivitou z hlediska délky, jednotlivých sdělovaných informací a jejich hloubky (2008, s. 246). Žádoucnost extendovaných promluv žáka musí souviset s rozsahem (žák má př́ležitost, motiv a podporu učitele, aby jeho promluva byla delší než obvykle), ale také s kvalitou ve smyslu obsahu řeči, který odráží posun v učení žáka. Vzhledem k tomu vycházím při pojetí extenzivní promluvy učitele nejen z hodnocení rozsahu jako délky.

Extenzivita je charakteristika každého řečového projevu. Jedná se o rozsahovou dimenzi řeči, která odkazuje jednak na délku a trvání řeči, jednak na informační bohatost. Znamená to, že řečový projev může dosahovat různé míry extenzivity, tedy být různě dlouhý a různě informačně nasycen. Oba aspekty musí zároveň odpovídat situační vázanosti řeči, recipient totiž předpokládá, že rozsah promluvy bude délkou i nasyceností informacemi odpovídat jeho očekávání. Pokud bychom toto pojetí ilustrovali na dvou různých projevech kupř́kladu v situaci odborné konference, můžeme uvažovat nad úvodním projevem pořadatele v kontrastu k plenární přednášce. První žánr bude podle očekávání účastníků méně extenzivní, přinášející informace, jaké příjemci pravděpodobně již znají, zároveň se předpokládá naplnění konvencí tohoto projevu (přivítání, poděkování, sdělení cíle setkání...). Plenární přednáška naopak musí být informačně více sycená, v delším rozsahu a trvání, ovšem taktéž zapadající do sdílených situačních očekávání účastníků konference. Ve výukové komunikaci je daná situace konkretizována možnými žánry řeči odpovídajícími účastníkům a cílům komunikace ve školní třídě. Lze předpokládat, že některé žánry promluv učitele se budou vyznačovat větším rozsahem i množstvím nových informačních jednotek a naopak, což ukazuje analýza dat v realizovaném výzkumu. 
Extenzivní promluva je segment řeči, který se vyznačuje délkou nad rámec běžného rozsahu u daného mluvčího, v tomto případě tedy učitele, a informační bohatostí, která se rovněž vymyká očekávání př́íjemce v situačním kontextu. Nadměrnost informací znamená vyšší kognitivní náročnost sdělení, ovšem pouze ve smyslu možností pro porozumění textu sdělení žáky, nikoliv jako podpůrný prostředek pro rozvoj jejich myšlení. Ve výukové komunikaci jde navíc o promluvy, u nichž hraje roli, zda umožňují reaktivitu jako základní, předpokládanou vlastnost dialogu, v němž jsou promluvy jednotlivých mluvčích adekvátně provázány. Specifikace uvedených aspektů, jimiž se extenzivní promluva vyznačuje, pro účely výzkumu, je představena v kapitole 7. 

Řeč učitele je základním nástrojem učení žáka, lze ji vnímat nejen jako produkt, výsledek, který můžeme hodnotit, ale komplexněji jako proces. Studie ukazují, že důležitou rolí učitele je řízení komunikace ve tř́́dě vzhledem ke stanovenému cíli a zajištění propojení řeči učitele s relevantní poznávací úrovní žákủ (Viiri \& Saari, 2006). V kontextu sociálního konstruktivismu je zásadním cílem řeči učitele podpořit citlivě učení žáků a jejich porozumění společně konstruovaným významům. Učitel by měl prostřednictvím řeči provázet žáky na cestě mezi předchozími poznatky a novým učením, podporovat provázanost mezi tím, co žáci již znají a novými informacemi (Myhill, 2006, s. 33). Vhodně a citlivě řízená komunikace ve třídě, při níž řeč učitele reflektuje, jak vnímá porozumění žákủ učivu, poskytuje oporu pro rozvoj myšlení. Při nastolení smysluplného učení se žáků se od učitele požaduje, aby pohled žáků nejen zapojil do vzájemné komunikace, ale aby s ním pracoval jako součástí společně konstruované znalosti (Lehesvuori, 2013). Žáci mají v ideálním případě možnost rozšírít a modifikovat schémata znalostí prostřednictvím vyjádřením svých idejí, jejich reformulacemi a reflexí (Burns \& Myhill, 2004, s. 36).

Reálný stav řeči učitele v prostředí třídy je ovšem opakovaně podrobován kritice, přičemž předmětem zkoumání je především verbální projev učitele a jeho jednotlivé formy. Výzkumy komunikace ve tř́ídě ve Velké Británii poukazují na zaměření ř eči učitele v první řadě na splnění cílů daných kurikulem. Učitelé se snaží žáky k naplnění cílů dovést prostřednictvím předpřipraveného scénáře, jehož potom v komunikaci pečlivě dodržují (Myhill, 2006). Učitel nečerpá dostatečně z veškerého potenciálu, který má řeč jako základní nástroj v edukačním procesu (Mercer \& Dawes, 2014). Komunikaci ve třídě chybí řeč jako živá, smysluplná součást životní zkušenosti (Fisher \& Larkin, 2008). Podle Cazdenové (2001) je základní potřebnou změnou přechod od recitace směrem k reálné diskuzi. Představit si komunikaci 
ve třídě, kde učitel zprostředkuje výměnu idejí nad rámec předem stanovených témat, není obtížné. Uvést tuto změnu do praxe vyžaduje však značné úsilí, na němž se musí podílet jak učitel, tak i žáci ve třídě. Učitel však zůstává nejdůležitějším aktérem možné změny a významnou roli zde hrají i předchozí zkušenosti učitele. Učitelé mají totiž sklon vyučovat takovým způsobem, jaký sami zažili v pozici žáků a ovlivňuje to i jejich přístup ke komunikaci a podílu na ní (Pimentel \& McNeill, 2013).

Řeč učitele by měla být sociocentrická, tedy orientovaná na příjemce, jimiž jsou žáci. Opačný případ egocentrismu v řeči se projevuje tím, že př́ijemce je nucen sám dekódovat sdělení komunikátora. „Případem egocentrismu jsou situace, kdy člověk použije jediný výraz pro hodnocení, např. Fajn., Špatně." (Vybíral, s. 110), což patří k frekventovanému vyjádření přímé, ale stručné zpětné vazby učitelem pro žáka (Mareš \& Křivohlavý, 1995; Gavora, 2005). Egocentrismus ve významu orientace učitele jako hlavního mluvčího ve třídě na sebe samého pak naznačují i získaná data.

\section{1}

\section{Řeč a komunikace podporující učení žáků}

Výzkumy komunikace ve třídě si často kladou za cíl nejen popsat skutečnost, ale diskutovat či dokonce prokazovat vazbu komunikace na učení žáků. Takto se kupříkladu autorský tým Scotta (Scott, Mortimer \& Aguiar, 2006) zabýval podporou smysluplného učení žáků v př́írodovědném vzdělávání. Na základě analýzy epizod vyučovacích hodin považují za nezbytný interaktivně dialogický přístup učitele, jehož podstata spočívá ve sdíleném srovnávání každodenních a vědeckých pohledů, jež reprezentují žákovské zkušenosti a/versus učitelovy vědomosti (zastřešené dále požadavky kurikula z hlediska vymezení obsahu, který by měl učitel v hodinách pokrýt). Učitel přitom vychází z cílů, které se následně odráží v celkovém komunikačním přístupu a ve struktuře komunikace ve třídě. Scott et al. (ibid) identifikovali učitelovy cíle (např. zaměřit se na pohled žáka a prozkoumat ho) na základě pozorování vyučovacích hodin přírodovědného vzdělávání, ale východiskem byly principy učení a vyučování v perspektivě Vygotského teorie.

Vygotského teorie se opírá o přesvědčení, že jazyk je základním nástrojem procesu učení. Řeč je tak nejen produktem, ale prostředkem pro učení a vyučování (Myhill, 2006). Jazyk a myšlení jsou v těsném sepětí. Poznání je umožněno sdílenou konstrukcí či rekonstrukcí sociálních významů v interakci s druhými lidmi prostřednictvím diskurzu, na což se v dnešní době zaměřuje ruská neo-vygotská škola (Sharpe, 2008). Zásadní vliv na teorie učení měla pak také Vygotským prezentovaná 
tzv. Zóna nejbližšího vývoje, tedy rozdíl mezi aktuálně dosahovanou a potenciálně možnou úrovní výkonu dítěte, zónu, na niž je třeba se zaměřit v procesu učení. V návaznosti na vliv této teorie pro aktuálně diskutované principy dialogického vyučování přichází Mercer (2002) s konceptem tzv. intermentální zóny vývoje (IDZ) umožňující učiteli a žáku rozvoj myšlení ve sdíleném procesu prostřednictvím dané činnosti, aniž by docházelo k neporozumění na obou stranách. Efektivita závisí především na schopnosti učitele vytvořit a udržet propojení mezi cíli danými kurikulem a exisujícími znalostmi, způsobilostmi a motivací jeho žáků (ibid).

V souvislosti s požadavky kurikula rozlišuje Olson dvě funkce jazyka v edukaci, které působí souběžně, avšak s odlišnou perspektivou, a mezi nimiž tak dochází neustále k tenzi: funkce jazyka pedagogická a institucionální (Olson, 1977 in Wells, 2006). Zvyšující se důraz na aktivizaci žáka v procesu učení vede ke snaze o dialogické vyučování, diskuzi při spolupráci nad problémy. Prosazuje se tak možnost progresivního diskurzu (Bereiter, 1994 in Wells, 2006), kdy žáci staví nové znalosti na zapojení vlastních zkušeností v jednotlivých předmětech, a kolaborativním učení, jež vede k hlubšímu porozumění počátečních tezí. Tento přístup se však neslučuje vždy s požadavkem jednotné znalosti žáků dané institucionálními měřítky, závazkem, že všichni studenti získají poznatky potřebné pro participování ve společnosti. Znalost je považována za dokončený produkt. Pokrytí požadavků kurikula způsobuje, že učitelé mají čas jen „bruslit po povrchu disciplín“ s memorováním faktů namísto rozvoje porozumění širším koncepčním rámcům v daných disciplínách (Wells, 2006, s. 172).

Dlouholetý výzkum výukové komunikace na různých typech škol a stupních vzdělávání se stal základem pro zobecnění charakteristik efektivněji komunikujících učitelů jako hlavních komunikátorů ve školní třídě, které předkládá Mercer (2002):

- Akceptace role průvodce při budování porozumění žáka, používání sekvencí otázek a odpovědí s cílem zjistit aktuální úroveň znalostí žáka, na jejímž základě lze postupovat ve výuce dále. Využívání dotazování k rozvoji myšlení a reflexe žáků.

- Odklon od převažujícího zaměření učitele na obsah vyučovaného předmětu, začlenění zkušeností žáků při řešení problémů, vysvětlování významu edukačních aktivit. Využití interakcí při komunikaci ve třídě k povzbuzení žáků k otevřenému vyjadřování.

- Pojetí učení jako sociálně komunikačního procesu. Motivace žáků k vyjadřování jejich názoru a postoje, prostor pro vzájemnou podporu mezi žáky, celkové vedení žáků k tomu, aby byli aktivními participanty dění ve třídě, jejichž hlas je slyšet. 
Vztah mezi učitelem a žákem v komunikaci je podle Nystranda et al. (2001) často omezen na vztah hodnotitele a začátečníka s organizací nastavenou na transmisi informací. Proto také autorský tým kolem Nystranda stejně jako další autoři (Alexander, Myhill, Mercer, Wells, Šed'ová, Švaříček et al., a další) hledají odpovědi na otázku, jak tuto situaci zlepšit ve výzkumech zaměřených na podporu a rozvoj principů dialogismu ve výukové komunikaci. V zorném poli výzkumů zůstává především učitel jako hlavní nositel případné změny. Prozatím se málo výzkumů zaměřilo i na žákovské strategie hledání opory pro učení zprostředkované učitelem či jiným dospělým edukátorem (Mercer, 2002), a tak se lze domnívat, že by širší propojení zahrnující i tyto strategie umožnilo maximalizaci snah o efektivní podobu komunikace ve tř́iě.

\subsection{1}

\section{Otázky učitele}

Zaměření na extenzivitu v řeči učitele nevylučuje zkoumání promluv, které mají formu otázky. Ve vztahu k řeči učitele podporující myšlení a učení žáků hrají jeho otázky důležitou roli, proto se jim v této kapitole chci stručně věnovat. „Učitelské otázky jsou považovány za klíčový prvek procesu učení" (Švaříček, 2011, s. 10), proto zůstávají zásadním tématem výzkumu v oblasti výukové komunikace jak v českém, tak i zahraničním měřítku. Cílem otázek učitele ve výuce je motivovat, podpořit a směrovat myšlenkové procesy dítěte (Sharpe, 2008). Badatelé zabývající se analýzou otázek ve výukové komunikaci zachytili zásadní rozdíl v dotazování při vyučování oproti běžné mezilidské komunikaci. Stejná otázka, jejíž funkcí je v běžné komunikaci zjistit informaci, se v interakci učitele se žákem stává prostředkem ověření vědomostí. I v životě pokládáme v některých př́ípadech ověřovací otázky, kterými zjišt'ujeme, zda komunikant má příslušnou znalost. Učitel se však na tento typ otázek orientuje $\mathrm{v}$ zásadně větší míře, jak ukazují mnohé minulé i současné výzkumy (Mehan, 1979; Burns \& Myhill, 2004; Nystrand et al., 2001; Šed’ová et al., 2012 aj.). Také školská komunikace pohledem lingvistického výzkumu rozlišuje tř́i základní typy otázek učitele, z nichž první odkazuje na popsaný jev:

- prověřovací otázky (Žáci mají znát odpověd');

- podněcující otázky (Učitel vede otázkou žáka k zamyšlení.);

- skutečné otázky (Učitel chce získat skutečné informace - vztahují se obvykle k organizaci třídy.).

Stejně jako v případě výzkumu výukové komunikace obecně, tak i pro oblast zkoumání otázek učitele platí zájem o vazbu na procesy a efektivitu učení žáků. 
Výzkumy zaměřené na prokázání vazby mezi frekvencí otázek vyšší kognitivní náročnosti a výsledky žáků však selhávaly, a to pravděpodobně proto, že otevřené otázky s vyšší kognitivní náročností nekorespondovaly s následnými testy faktických znalost a že byly realizovány při běžné frontální výuce s větším počtem žáků (Švaříček, 2011). Brněnský výzkumný tým Šed'ová, Švaříček a Šalamounová se zaměřil na analýzu učitelských otázek na druhém stupni základní školy v humanitních předmětech z hlediska dvou základních posuzovaných dimenzí. První bylo rozlišení otázek na otevřené či uzavřené, přičemž uzavřená otázka přináší pouze jedinou správnou odpověd', kterou učitel předem zná a především v tu chvíli od žáků vyžaduje. Druhou dimenzí se stala právě kognitivní úroveň pokládaných učitelských otázek a spojením obou vznikla typologie s podrobnými výsledky a př́klady z analyzovaných hodin. Kognitivní náročnost otázek byla zasazena do modelu revidované Bloomovy taxonomie se šesti úrovněmi kognitivních procesů (Šed'ová et al., 2012, s. 60). Otázky nižší kognitivní náročnosti pak odpovídají pouze první, nejnižší úrovni procesů, zapamatovat si učitelem prezentovaný fakt. Cílem této části výzkumu komunikace ve třídě bylo zjistit, jaké typy otázek se na daném stupni vzdělávání vyskytují, přičemž souhrnné zjištění přineslo třetinové rozložení otázek - ze všech uzavřených otázek byly dvě třetiny nižší kognitivní úrovně, zatímco v př́padě otevřených otázek platilo, že dvě třetiny z nich patřily k vyšší kognitivní náročnosti na procesy žáků. Z hlediska dopadu typů učitelských otázek byla zajímavá především korespondence daného typu s následnou odpovědí žáka (ibid, s. 86), což naznačuje, že učitel je tím, kdo zůstává „na tahu“, aby ovlivnil tuto zásadní oblast výukové komunikace (podobně také Nystrand et al., 2001, s. 9).

Prozkoumat podobně zvolené aspekty otázek učitele ve výukové komunikaci bylo jedním ze záměrů také v rozsáhlém šetření Nystranda et al. (2001). Jejich datový soubor složený ze 33 tisíc otázek se stal dostatečným materiálem pro návrh na rozlišení dialogu a otevřené diskuze a dále pro momenty ve výukové komunikaci, které vedou k přepínání z monologické podoby na dialogické signály ve výukové komunikaci. Autoři (Nystrand et al., 2001, s. 17) zvolili rozdílný přístup k určení kognitivní úrovně otázky, opírají se o rozlišení mezi rutinními a heuristickými akty s následujícími faktory:

- Erudovanost žáka odpovídajícího na otázku (zpětné získání informací od žáků k jednotlivým otázkám s cílem zjistit, zda museli odpovídat na základě již existující informace, nebo sami skutečnost vyvodili);

- Zkušenost, schopnost a předchozí znalosti žáka;

- Podoba výukové činnosti (korespondence rozlišení typu s probíhající činností i v př́ípadech, že lingvistická podoba odkazuje na první pohled k jinému typu);

- Požadovaný zdroj informací (otázka samotná versus jiné dostupné informační zdroje). 
Podstatným a inspirativním faktorem pro rozlišení kognitivní náročnosti otázky byla její existence v daném kontextu v průběhu komunikace ve třídě. Formou tatáž otázka tak mohla být hodnocena odlišně. I didakticky žádoucí analytická otázka „Proč?“ se totiž může vztahovat jak k požadavku analýzy ze strany myšlenkové operace žáka, tak i k pouhému přednesu analýzy uvedené již v jiném zdroji - prezentaci učitele, učebnici apod. Tento aspekt ztěžoval výzkumníkům práci nad rozsáhlým datovým souborem, ale příklon k pouhé lingvistické struktuře by jinak mohl přinést zkreslené výsledky z hlediska výskytu typů. Stejně autoři přistupovali i k dimenzi otevřená - zavřená otázka, v jejich podání se jedná o tzv. autentické otázky přinášející jinou než předvídanou odpověd' a signalizující učiteli zájem žáka o problematiku, přičemž v protikladu k autentickým stojí otázky univokální, tedy s jedinou možnou správnou odpovědí. Autenticita otázky musí být rovněž posuzována s ohledem na její kontext v komunikaci (ibid).

Potřebu znalosti kontextu probíhající i předchozí výuky pro adekvátní posouzení otázky učitele zdůrazňuje rovněž Myhillová (2006). Typologie otázek prezentovaná v její studii vychází z podstaty možné odpovědi žáka a shodně s dalšími výzkumy ukazuje na dominanci faktických otázek (více než 60 \% z celkového počtu), tedy s predeterminovanou odpovědí obvykle s uzavřenou formou. Dalšími identifikovanými typy v rámci tohoto výzkumu realizovaného na prvním i druhém stupni se zaměřením na hromadnou výuku jsou otázky procedurální (management vyučovací hodiny), procesní (žákova explanace procesu myšlení nad problémem) a úvahové (otevírající možnost vyjádření názoru, hypotézy, idejí, představ apod.). Poslední uvedené dva typy, které by měly ve výukové komunikaci reprezentovat podporu učení žáka, nedosahovaly ani jedné třetiny výskytu. Rozvažování (speculation) je shodně s Nystrandem (2001, s. 17) pojímáno jako nejvyšší úroveň kognitivní náročnosti otázek. Záznamy výukových epizod výzkumu Myhillové sloužily také jako nástroj pro následnou reflexi samotných učitelů. Je zajímavé, že v rozhovorech, které předcházely zhlédnutí záznamu, učitelé vyjadřovali silné přesvědčení o variabilitě vlastních otázek z hlediska typu i formy. Rozpor mezi přesvědčením učitele a zachycením reality se objevil jak ve výzkumu Šed'ové et al. (2012), tak i v předkládaném výzkumu, kdy učitelé vnímají extenzivní promluvy jen jako souvislou přednášku, jaká není v jejich hodinách přítomna.

Řeč učitele podporující učení žáků se zastavením se u významu otázek učitele nacházíme i ve studii Sharpové (2008), jež se pro práci s daty opírá o lingvistickou systemickou funkční analýzu a identifikuje strategie učitele odpovídající konceptu přisvojování a transformace promluv žáků, které učitel následně nabídne v rekontextualizované verzi, a specifické podpory ve formě tzv. lešení (scaffolding), jehož se dotkneme v následující kapitole. 


\subsection{2}

\section{Od lešení k dialogickému vyučování}

Podle Mercera je cílem komunikace ve třídě vybudovat lešení pro učení žáka $\mathrm{k}$ podpoře vytváření a porozumění významům samostatně s učitelem jako citlivým „průvodcem“ (Mercer, 2002). Samotný metaforický pojem lešení byl přitom poprvé použit Brunerem se snahou vystihnout možnosti efektivní intervence učitele ve výuce tak, aby podpořil dosažení cíle, jehož si stanovil, ale zároveň nabídl určitou formu pomoci, která v důsledku povede k rozvoji kompetence žáka umožňující řešení obdobných problémů již samostatně (Sharpe, 2008). Učitel musí přitom vzít v potaz propojení mezi dosavadním poznáním u žáka a nově předkládanými poznatky, na nichž se žák aktivně podílí. Zodpovědnost za celý proces je rovnoměrně rozložená mezi všechny participanty a učitel v roli průvodce ponechává žákovi stále větší autonomii (Myhill, 2006).

Podstatou dialogu ve výukové komunikaci je sdílené hledání významu s postupným směřováním $\mathrm{k}$ řešení problému prostřednictvím poskytování lešení ze strany učitele (Alexander, 2006 in Šed'ová et al., 2012). Učitelé vnímají žáky jako potenciální zdroj poznání, zajímají se o jejich pohled a názory na probírané téma. Porozumění je pak namísto recitace vyvolávané znalosti zasazeno do transformace prostřednictvím interakce mezi učitelem a žáky (Nystrand et al., 2001, s. 4). Ve zmíněných přístupech tak rezonuje především kognitivní funkce dialogu, kterou Janíková (2011) doplňuje o afektivní a sociální. Učitel má možnost ovlivňovat pozitivně motivaci k učení žáka, který neprochází frustračním tlakem zodpovídání otázek postavených na jediné správné odpovědi k prověřování znalostí. Podpora více hlasů v komunikaci nad jedním tématem pak může opět pozitivně působit na vztahy žáků ve třídě, na rozvoj kooperace a prosociálních dovedností.

Základní prvky dialogického vyučování, jež jsou založeny na vnímání vzájemného přispění k učení, opory a rozvoje na straně učitele i žáka, vymezuje Alexander (2006):

- kolektivismus,

- reciprocita,

- podpora,

- kumulativnost,

- smysluplnost.

Na dialogu založené dialogické vyučování musí splňovat podmínky, k nimž patří kupř́íkladu základní charakteristiky komunikace, jak je stanovil Applebee s kolegy (2003). V předchozí kapitole byly již zpracovány učitelské otázky jako jeden ze zásadních faktorů, konkrétně pak tzv. autentické otázky jako 
předpoklad pro rozvinutí otevřené diskuze mezi učitelem a žáky (Šed'ová et al., 2012). Kromě otázek učitele jsou především žákovské otázky silným zdrojem dialogičnosti ve třídě. Jakmile učitel „dovolí“, aby komunikace ve tř́́dě plynula směrem, který byl určen dotazem položeným žákem, namísto rychlého přesunu zpět k původnímu plánu nebo převzetím kontroly vlastními otázkami, se otevírá cesta $\mathrm{k}$ dosažení otevřené diskuze jako nejčistší podoby dialogu ve výuce (Nystrand et al., 2001).

Dalšími kritérii, jež posouvají diskuzi k produktivnímu dialogu (ibid), je reaktivita, tedy provázanost výměn, v nichž je téma postupně společně rozvíjeno, aniž by učitel směřoval pouze k předpřipravenému závěru diskuze, a v neposlední řadě evaluace vyššího řádu, kterou opakovaně zkoumal Nystrand $(1997,2001)$. Učitelovy promluvy jsou jednotlivými segmenty, jež jsou součástí různých forem, vzorců či struktur vznikajících v komunikaci mezi učitelem a žákem/ žáky během dané vyučovací jednotky. Každá promluva je potenciálním stimulem pro vyvolání další promluvy, reakce na straně adresáta (Bosák, 1974), kterým je v komunikaci ve trrídě žák nebo více žáků. Zásadním prvkem jejich vzájemné interakce vedoucím k porozumění obsahu komunikace by měla být reaktivita promluv, tedy provázanost, výstavba promluv na základě spojitosti s předchozími. Reaktivita spočívá v explicitním reagování na předcházející repliku (Vávrová \& Gavora, 2014, s. 116), jedná se o vlastnost dialogu produkovat repliky, které nejsou izolovanými promluvami. Promítá se zde požadavek akceptace nutnosti změny v plánované komunikaci podle aktuální potřeby, která ovšem vyžaduje, aby učitel nenastavil svou komunikační roli pouze jako dominantní, řídící průběh komunikace ve výuce.

Reaktivita se jako celková provázanost sdělovaných promluv vztahuje ke zpětné vazbě. Zpětná vazba je pojímána jedna ze složek struktury výukové komunikace a patří $\mathrm{k}$ významným aspektům výzkumu, protože z pohledu některých autorů je důležitějším dokladem kvality či nekvality dialogu ve školní třídě než otázky učitele (Smith \& Higgins, 2016 in Šed'ová \& Švařriček, 2010, s. 64). Základem konceptu zpětné vazby je hodnocení předchozí žákovské promluvy učitelem z hlediska průběhu jeho procesu učení (Šed'ová et al., 2012). Výzkumy reálné komunikace ve školní třídě ovšem ukazují, že zpětnovazební promluvy učitele mohou být z hlediska transmise hodnocení vyprázdněné (Šed'ová \& Švaříček, 2010). V rámci pedagogického výzkumu vznikají různé ty pologie zpětné vazby vázané na zvolené aspekty jednotlivých autorů (např. Mareš \& Křivohlavý, 1995; Gavora, 2005; Chin, 2006; aj., Šed'ová et al., 2012). Ve vztahu k žánrům promluv učitele se konkrétně dozvídáme, že v převládající struktuře IRF se po nesprávné odpovědi žáka neobjevuje zpětná vazba učitele ve formě výkladu (Šed’ová et al., 2012). Tento aspekt zpětné vazby ovšem kontrastuje s analyzovanými daty, jak ukazuje dále kapitola 8.4.1.1 zaměřená na reaktivitu extenzivních promluv. 
Výzkum Myhillové (2006) zaměřený široce na vliv řeči učitele na vytváření lešení pro učení žáků opakovaně potvrdil učitelovu dominanci v komunikaci. Myhillová uvádí, že „učitelé se zdráhali předat kontrolu nad komunikací ze strachu, že nepokryjí v hodině vše, co je potřeba probrat." (s. 29). Vzhledem k tomu, jak se v mezinárodním a posléze i českém měřítku nabalovala zjištění tohoto typu, začaly se v reakci na potřebu zefektivnit výukovou komunikaci zkoumat také možnosti aplikace dialogického vyučování do reálné výuky. Cambridgeská univerzita v čele s Mercerem podporuje učitele v rámci projektu Thinking Together (@ 2017 Thinking Together), širší projekty kombinující podporu učitelů v získávání kompetencí potřebných pro aplikaci principů dialogičnosti a následné pozorování případných změn v reálné výuce přinášejí také Alexander (2006) i Lefstein a Snell (2014, in Šed’ová et al., 2014). Britský projekt „TALK“ (Using Talk to Activate Learners' Knowledge') je rovněž postaven na akčním výzkumu rozvoje interaktivity ve výukové komunikaci (Burns \& Myhill, 2004). Inspirací pro české prostředí je realizovaný akční výzkum dialogického vyučování na př́íkladu učících se učitelů autorského kolektivu Šed'ová, Švaříček, Šalamounová a Sedláček $(2014 ; 2016)$, v němž se podařilo docílit proměny výukové komunikace ve vybraných aspektech patřících k dialogickému vyučování, jakým je i triadická interakce ve třídě (Molinari \&Mameli, 2015).

\section{2}

\section{Verbální moc učitele}

Název této dílčí kapitoly odkazuje svým zaměřením na učitele jako dominantního aktéra výukové komunikace a jeho zásadní vliv na podobu a průběh komunikace ve tř́́dě. Komunikace mezi učitelem a žáky ve třídě je popisována jako asymetrická $\mathrm{s}$ nastavenými rolemi učitele jako nadřízeného komunikátora, jenž obvykle rozhoduje o tom, kdo, jakým způsobem či jak dlouho bude ve tř́íde mluvit (Nelešovská, 2005; Janíková, 2011). Učitel určuje téma komunikace, ovlivňuje její směr a rozhoduje o adresátovi (Chvalovská, in Hoffmannová et al., 2016, s. 226). V této části se tedy zaměřím především na dominanci učitele projevovanou prostřednictvím verbálního projevu, jejímž cílem je, jak se domnívám, spíše kontrola nad třídou jako celkem, kontrola nad probíhajícím procesem vyučování, učitelovo soustředění se na zvládnutí tématu výuky. Na rozdíl od běžné konverzace diskurz ve školní třídě je typicky zasazen do participační struktury kontrolované jediným konverzujícím - učitelem (Nystrand et al., 2001).

Mortimer a Scott (2003) přicházejí později společně i s Aguiarem (2006) v jedné ze studií s argumentem, že každá sekvence vyučovací hodiny (v tomto případě zaměřené na vyučování přírodních věd) má vždy za následek jak dialogické, tak 
i autoritativní pasáže interakce učitele s třídou. Pojetí těchto dvou přístupů učitele k diskurzu ve třídě je založen na Bachtinově rozlišení (Bachtin, 1981 in Scott et al., 2006) mezi autoritativním a vnitřně přesvědčivým diskurzem. Autoři demonstrují př́ístupy na záznamech sekvencí z výuky, popisují přitom jak verbální, tak i neverbální projevy učitele i žáků. Výsledkem jejich analýzy se staly čtyři typy komunikačního přístupu vycházející ze základních dimenzí vyjádřených protiklady interaktivní - neinteraktivní a dialogický - autoritativní:

- Interaktivní dialogický: učitel společně s žáky uvažují nad celou škálou idejí k tématu, pokládají pravé otázky. Ideje jsou následně bud' rozvíjeny, nebo zůstávají jen jako možné pohledy.

- Neinteraktivní dialogický: učitel opakuje a sumarizuje téma z různých pohledů.

- Interaktivní autoritativní: učitel se zaměřuje na konkrétní stanovisko v rámci učiva a vede k němu studenty prostřednictvím rutinního vzorce otázka - odpověd'.

- Neinteraktivní autoritativní: učitel pouze prezentuje konkrétní stanovisko v rámci učiva.

(Scott et al., 2006, s. 611).

Autoritativní přístup učitele spočívá v záměru učitele zacílit pozornost žáků k jedinému významu prezentovaného obsahu. Tento přístup pak kontrastuje s dialogickým, kdy jsou brány v potaz také významy předkládané dalšími účastníky komunikace. Učitel v autoritativním diskurzu uzavírá žákům přístup ke komunikaci ve smyslu chybějícího rozvedení jejich výpovědí, žákovské hlasy v hodině sice zaznívají, ale učitel je pouze mechanicky přijme a dále s nimi nepracuje jako s relevantními pokusy o hledání různých možných perspektiv, jak nahlížet na prezentované téma ve výuce. Žákovské otázky (pokud se vůbec vyskytují) jsou přetvořeny tak, aby vyhovovaly učitelově předem připravené práci s tématem, nebo ignorovány.

Autorita může být vymezena jako forma moci s projevy manipulace, donucování a přesvědčování (Wrong, 2002). Komunikace obecně má mocenský rozměr, i prostředí školy se dotýká vymezení rovin komunikace na obsahovou a vztahovou tak, jak ji popisuje Watzlawick, Bavelas, \& Jackson (2011). Stejně tak McCroskey opakovaně konstatuje, že určitý stupeň moci učitele je ve třídě vždy přítomný a čím více je moc používaným prostředkem učitele, tím více ji učitel bude muset užívat i nadále pro udržení kontroly nad třídou (1978, 1982, 2005). Mezi druhy moci, které uvádí DeVito (2008), se učitele týká především moc odměňovací, protože ovládá známkování, poskytuje doporučení, ale formuje i celkové žákovo sebehodnocení v rámci skupiny ve třídě. Moc je McCroskeym a Richmondovou (1982, s. 2) definována na základě analýzy př́ístupů mnoha různých autorů a jejich vlastních 
výzkumných zkušeností jako potenciální možnost jednotlivce ovlivnit chování další osoby či skupiny osob.

Strategie učitele, jak zpracovat moc, která souvisí s jeho formální rolí ve třídě a snahou dokázat změnit chování žáků, jsou zásadní pro efektivní řízení třídy. Pedagogické strategie učitele jako formy a metody výuky, volba činností, způsobilost $\mathrm{k}$ řešení problémů a vedení skupiny, to vše, stejně jako další podmínky, představuje kombinované faktory průběhu výuky. Ovšem i v př́ípadě adekvátního nastavení podmínek potřebuje učitel vědět, jak lze na žáky pưsobit, když je plánovaná činnost žáků narušena a je třeba ovlivnit jejich chování a připoutat zájem opět k učebním aktivitám (Plax, Kearney, McCroskey \& Richmond, 1986).

Učitelova moc v rámci neadekvátního uplatňování ve tř́ídě souvisí také s pojmem „učitelovo nevhodné chování“, který vyjadřuje jednání učitele poškozující žáka na různých úrovních projevů. K těm patříignorace žáka, který se hlásí, soustavné komentáře na vybraného žáka ve třídě, sarkasmus, verbální i neverbální urážky, nezodpovězení otázek položených žáky, nezájem o názory žáků odlišné od učitelem prezentovaných tezí a další. Kromě negativního vlivu na psychiku žáka má takové chování učitele dopad také na žákovo myšlení, znesnadňuje proces jeho učení. Způsobuje rovněž menší míru participace žáků na komunikaci a snižuje celkově jejich spokojenost s komunikací ve trrídě (Mareš, 2013). Žádoucí je přitom přístup učitele založený na pozitivní komunikaci, která zvyšuje pravděpodobnost tvořivého myšlení a úspěšného řešení zadaných úkolů (Vybíral, 2005, s. 231). Zkoumání důvodů učitelova nevhodného chování jsou součástí teorie interakčního stylu učitele a širší teorie uplatňování moci. McCroskey et al. rozlišili pět typů učitelovy moci nad žáky ve škole:

- moc založená na donucování - uplatnění moci trestáním žáků;

- moc založená na odměňování - síla učitelovy pochvaly, další odměny či odpuštění trestu;

- moc založená na legitimitě - formální postavení učitele ve třídě;

- moc založená na expertnosti - získání moci na základě profesních kvalit;

- moc založená na sympatiích - nepř́má moc vyvolaná př́ijemným, empatickým vystupováním učitele

(Mareš, 2013, s. 16).

Učitel se v dominantním působení opírá také o institucionální zdroj moci, reprezentovaný kázeňskými pravidly, jež má učitel zprostředkovávat žákům a být sám vzorem v jejich akceptaci a aktivním naplnění.

Akceptace (často implicitně) stanovených pravidel v komunikaci však může představovat pouhý ritualismus jako jeden z typů žákovského chování vůči učiteli ve vzájemné interakci (Woods, 1979 in Šed'ová et al., 2012). Žáci navenek přijímají 
autoritu učitele, avšak neztotožňují se se striktně nastavenými pravidly. Takový ritualismus umožňuje žákủm „přežít“ učitelem projevovanou a centralizovanou moc ve třídě. V komunikaci jsou žákovské iniciace potlačovány, učitel se soustřed'uje na dodržování žákovského registru představujícího právě pravidla jejich promluv z hlediska požadavků učitele (Šed’ová et al., 2012). Analýza dat získaných při realizaci výzkumu brněnského kolektivu Šed'ová, Švaříček a Šalamounová přinesla také zjištění v podobě tzv. mocenských konstelací, tedy vztahů, v nichž hraje roli moc, ovšem na obou stranách, jak u učitelů, tak i žáků jako výsledku oboustranné interakce. Jeden z typů odhalených mocenských konstelací ve tř́ídě vychází právě z ritualismu a autory byl pojmenován „přesilovka“. Misky vah se v tomto př́padě naklání ve prospěch učitele jako nejsilnějšího zdroje moci ve třídě. Takový případ se vynořil i při analýze dat $v$ předkládaném výzkumu a reprezentuje ho učitelka Adéla jako typ učitele, který žáky nepustí téměř ke slovu a neustále je napomíná. Z celkových čtyř typů mocenských konstelací se dominance učitele projevuje také tzv. zobáním z ruky, ovšem tento př́pad je žáky akceptován bez zpochybňování (Šed'ová et al., 2012).

Nastavená pravidla jsou součástí scénáře interakcí ve třídě, kdy režisérem je obvykle učitel. Někdy se však nesourodá pravidla týkají především kvantity, rozložení a forem řeči učitele a především žáků. Edwards a Furlong (1978) poukázali na významný aspekt role učitele ve třídě, a tím je právě neustálé monitorování a řízení průběhu komunikace ve třídě. Na příkladu zachycených dat z pozorování učitelů 2. stupně základních škol představili kategorie odpovídající této roli a vycházeli přitom z typologie tzv. metavýroků učitele od Stubbse (in Mercer \& Dawes, 2014). Jedná se o následující typy direktivních výroků:

- upoutání pozornosti;

- kontrolování rozsahu a rozložení řeči;

- upřesňování tématu;

- proveř̌ování či potvrzování porozumění;;

- opravování a upravování řečeného;

- sumarizování.

Všechny představené typy výroků byly zachyceny jako součást extenzivních promluv učitelů, kupř́íkladu poutání pozornosti bylo identifikováno jako jedna ze strategií učitele v expozičním žánru (viz kap. 8.1).

Ačkoliv současné přístupy ke vzdělávání zdůrazňují orientaci na dítě/žáka, což by mělo vést k oslabení učitelovy dominance ve tř́ídě, Myhillová (2006, s. 19) konstatuje, že mnohé studie realizované během několika uplynulých desetiletí opakovaně ukazují na silnou tendenci učitele dominovat v komunikačních scénářích ve třídě. Učitel je označován jako „kontrolor mluveného slova“, „precizní 
organizátor řečových příležitostí ve tř́ídě", zatímco žáci v důsledku takového rozložení „papouškují, zrcadlí a snaží se vybavit si, co řekl učitel“. „Interakce je redukovaná na řeč učitele s pauzami, kam mohou studenti vložit své odpovědi.“ (Francis, in Myhill, 2006). Role učitele je vymezena jako role „přenašeče daných informací" (Sharpe, 2008, s. 133), zatímco by měla spočívat spíše ve facilitování a spolukonstruování nových informací žákům. Jedním z možných vysvětlení, proč dominance učitele v komunikaci ve tř́́dě přetrvává, je podle Viiri a Saari (2006) opakující se zkušenost. Současní učitelé tedy v mnohých př́ípadech mohou napodobovat vzorce komunikace, jaké sami poznali v roli žáka. Se zajímavým důsledkem ustálených vzorců v řeči učitele přišel také Haworth (in Fisher \& Larkin, 2008). Zjistil totiž, že je přejímali také žáci během vzájemné komunikace při práci ve skupinách.

Učitelům i výzkumníkům se nabízí hledání odpovědi na otázku, jak udržet ve třídě kontrolu nad nastolenými pravidly a zároveň se nedopouštět nevhodného chování. Mezi potencionální techniky, které umožní kooperaci žáků a limitují problémy s disciplínou, patří pobídky žáků ke komunikaci, strukturované změny v komunikaci, motivační prohlášení či pozitivní dotazování (Plax et al., 1986). Jedná se tedy o adekvátní techniky patřící k projevům verbální moci a kontroly učitele, která je v interakci se žáky ve tř́́dě vždy přítomná. Pohled na projevy a strategie verbální kontroly učitele jsou obvykle doplňovány také o neverbální prostředky, jež mohou být i silnějším zdrojem jak pozitivního, tak negativního působení učitele na žáky. Spojení verbální komunikace s neverbální jsem primárně nevěnovala pozornost, ale použité jazykové prostředky učitele v extenzivních promluvách jsou doplňovány o postřehy k paralingvistickým i extralingvistickým prvkům. 



\section{ŽÁNRY VÝUKOVÉ KOMUNIKACE}

Veškeré komunikační jednání se odehrává v určitém žánrovém rámci. „Mluvíme v různých žánrech, aniž bychom si uvědomovali, že existují." (Bachtin, 1986, s. 78). Možnost přiřadit každou řečovou promluvu člověka k určitému žánru, s ohledem na sociální kontext komunikace, je zřejmě důvodem pro množství definicí žánrů rámovaných různými autorskými př́stupy. Jak konstatuje Dontcheva-Navratilova (2017, s. 6), „definování konceptu žánru zůstává výzvou navzdory početným publikacím posledních dvou dekád zabývajících se žánrovou analýzou mluveného i písemného diskurzu v rozmanitých disciplínách.“. V této kapitole tak pojednám o vybraných pojetích žánrů a jejich typologií jak obecně, napříč disciplínami studujícími komunikační žánry, tak i pohledem pedagogiky v kontextu výukové komunikace. $V$ závěru kapitoly představím definici žánru, která je výsledkem zkoumání prezentovaných zdrojů, a typologii, jež se nejvíce blíží k vymezení typů žánrů na základě analýzy datového materiálu.

Žánr je definován jako stabilní forma promluvy, sociálně konstruována v daném okamžiku, kdy je pronesena v řeči. Yatesová a Orlikowski (1992) popisují žánry jako typizované komunikační jednání charakterizované jednotou obsahu a formy a uskutečněné jako odezva na opakující se situace v komunikaci. Jednota obsahu a formy žánru jako základní charakteristika se objevuje také v definicích lingvistické literatury, dodnes citované je pojetí Mistríka (1975), který vymezuje žánr jako model formálně i obsahově uzavřeného kontextového celku. Mistrík pojednává o žánrech nad rámec tradičních literárních textů a dále zdůrazňuje, že samotný pojem žánr je pro vyjádření formálně i obsahově jednotného celku používán v mnoha dalších oborech jako sociologii či geologii.

Obecnou funkcí žánrů je umožnění rozpoznání významů v promluvách prostřednictvím formalizovaného a rutinního jazykového jednání. Komunikační žánr 
má vnitřní i vnější strukturu. Vnitřní se týká využitelných vyjadřovacích systémů typických pro daný žánr, ty zahrnují jak verbální, tak neverbální systémy, které zároveň ukazují na jednotnost v rámci celého stylu. Vnější struktura žánru určuje jeho zakotvení v komunikačním prostředí a situacích a propojení také s typickými komunikačními interakcemi. Př́́kladem odpovídajícího žánru v univerzitním prostředí je tak přednáška (Auer, 2014, s. 169-170).

Ve školní komunikaci se pohledem lingvistiky objevují žánry rozlišené na základě dvou kritérií. Prvním je rozdělení na žánry mluvené a psané, což je obvyklé kritérium stylistiky, druhým potom vymezení žánrů podle adresáta. Autoři pracují s pojmem školní komunikace, který odkazuje ke specifikům komunikace probíhající v kontextu institucionalizované edukace s mnoha vnitřními komunikačními pravidly v interakci učitele a žáka (Höflerová, 2003). Mezi mluvené žánry školní komunikace patří:

- výklad (monolog učitele);

- organizační dialog učitel - žák;

- výukový dialog učitel - žák (žáci), zkoušení;

- monolog žáka;

- dialog mezi žáky při skupinových pracích

(Chvalovská in Hoffmannová, 2016, s. 230).

Běžně pak dochází k prolínání žánru výkladu učitele a výukového dialogu. Průlom dialogu do probíhajícího výkladu učitele je podle Chvalovské (ibid) odrazem vnímání atmosféry ve třídě, kdy se ztrácí pozornost žáků nebo dávají učiteli najevo, že obsahu neporozuměli, a proto učitel výklad přeruší a navazuje rozhovorem.

Hlubší rozměr žánrů nastavuje lingvistická etnografie čerpající z práce Dell Hymese. Využívá pro výzkum řečových aktů jím navržený systém nazvaný SPEAKING, přičemž každé písmo z názvu reprezentuje jednu komponentu systému. Poslední komponentou „G“ je žánr řečového aktu, tedy kupříkladu přednáška, báseň či dopis. Žánr jako typ řečové události je zasazen do řečové situace a dále se v něm vyskytují konkrétní akty. Př́íkladem je konverzace (= co se děje - událost) při oslavě (= kde se to děje - situace), v níž zazní vtip (akt) (Johnstone \& Marcellino, 2010).

Při zaměření na žánry ve spojení s výukovou komunikací nenacházíme v pedagogické literatuře mnoho zdrojů. Jako žánry jsou označeny druhy komunikačních situací v práci Alexandera (2006), tedy s vazbou na kontextovou vázanost žánrů. Jedná se však o ekvivalent druhů situací, o překlad z „kinds of teaching talk“, tedy autor sám nepoužívá přímo pojem žánr. Přesto jeho vymezení komunikačních situací lze považovat za žánry v našem pojetí a přináší následující typologii:

- Drilování (výměny mezi učitelem a třídou): mechanické opakování založené na pamět'ovém učení. 
- Recitace (výměny mezi učitelem a třídou nebo učitelem a skupinou žáků): zodpovídání otázek učitele, převážně uzavřených, které mají charakter přípravy žáků na testy/zkoušení, cílem je vyvolat poznatky uložené v paměti žáků. Otázky učitele často obsahují klíče napovídající, jaká je správná odpověd'.

- Instrukce/ expozice (výměny mezi učitelem a tř́́dou nebo skupinou žáků nebo učitele a jedním žákem): výklad, vysvětlení či instrukční sdělení, obvykle $v$ monologické formě.

- Diskuze (výměny jako v předchozích případech s obohacením o variantu žáka s žákem): výměna idejí mezi participanty výukové komunikace navzájem

- Dialog (výměny jako $\mathrm{v}$ předchozích případech s obohacením o variantu žáka $\mathrm{s}$ žákem): dosažení sdíleného porozumění prostřednictvím nadstavby dialogu s lešením.

Často diskutovanými žánry z Alexandrovy typologie jsou recitace jako frekventovaný a nežádoucí jev ve vyučování v opozici vůči požadované cestě v komunikaci učitele přes diskuzi ke skutečnému dialogu se žáky (Mehan, 1979; Myhill, 2006 aj.). Recitace je typicky zasazena do prostoru vymezeného body, které představují jed notlivé informace, jež chce učitel ve vyučování pokrýt. Predominance recitace ve vyučování je opakovaně potvrzována empirickými studiemi v USA, přičemž absentuje i koherence mezi předkládanými tématy (Nystrand et al., 2001, s. 5). Monologický diskurz vnímá Nystrand (ibid, s. 4) jako užitečný pro stanovení tématu výuky a sdělení výchozích informací, na něj by pak měla už navázat diskuze, která otevře cestu k projednávání idejí a novému porozumění.

Autoři pojednávající o žánrech v komunikaci své pojetí opírají často o teoretický rámec Hallidaye a systémovou funkční lingvistiku. Dochází tedy k propojení pohledu lingvistiky a pedagogiky. Teorie systémové funkční lingvistiky staví na tezi, že jakýkoliv text v psané či mluvené podobě je kontextualizován v daném prostředí, čímž se aktivuje jeho význam. Jazyk je sémiotickým systémem, zdrojem významu. Halliday kladl důraz na budování kontinuity mezi jazykem žáků a standardním jazykem školního vzdělávání (Frankel, 2013). Teorie jazyka Hallidaye a především jeho generická struktura byla zdrojem, z nějž vychází Young, který prezentuje 4 žánry komunikace ve tř́ídě založené na funkci otázek kladených učitelem, o němž také uvádí, že je dominantním tazatelem ve třídě (Young, 1992, s. 90):

- Co žáci vědí (WDPK - What do pupils know): Učitel klade otázky s cílem zjistit, zda žáci znají správnou odpověd'. Učitel je jediným „,soudcem“, který o správnosti rozhoduje. Žánr má evaluační funkci.

- Hádej, co si myslí učitel (GWTT - Guess what teacher thinks): Učitel vytváří dojem, že žáci při odpovědi sami přicházejí na řešení, ačkoliv učitel předdefinovanou správnou odpověd' už zná. Žánr má rekonstrukční funkci. 
- Odhalení (FO - Finding out): Učitel se dotazuje na osobní záležitosti žáků, často z organizačních důvodů. Žánr má personální funkci.

- Kritický diskurz (CO - Critical Discourse): Učitel klade otázku, která může mít také předem známou odpověd', ale celý komunikační proces vede k prezentaci názorů žáků, vyvolá také jejich vlastní otázky.

Důležitým výstupem Youngovy typologie je zjištění, že pouze poslední z identifikovaných žánrů poskytuje žákům výchozí prostor pro kritické autonomní myšlení.

Z žánrů stanovených Youngem vychází později Mejía a Molinová (2007), ale doplňují další aspekty, které je potřeba analyzovat při zkoumání kritického autonomního myšlení. Přidávají tak další žánry, přičemž se stále jedná o žánry identifikované na základě interakce učitele a žáka při kladení otázek, a představují analýzu a pojmenování určité struktury zasazené do očekávání v rolích. Neomezují se přitom na roli učitele, přestože výuku vede učitel, ale rovněž zjišt'ují, že jednotlivé žánry se mohou prolínat s různým stupněm dominance mezi nimi. Tito autoři také diskutují pojetí Hallidaye i Younga, které interpretují jako přehled ideálních typů, jejichž cílem je ukázat, jaké typické žánry se objeví v komunikaci v dané situaci po určitou dobu, a mají objasňovat účastníkům jejich roli v komunikaci ve tř́́dě. Young se zaměřuje na struktury, stranou však ponechává obsah promluv ve třídě (Mejía \& Molina, 2007, s. 420) a celkově můžeme jeho pojetí vnímat dnes jako výchozí bod pro rozpracovanější analýzy.

Výzkumy výukové komunikace v českém prostředí se dotkly také některých žánrů, jak je dále vymezuje tento text. Videostudie fyziky Janíka a Mikové (2006) se kromě dalších aspektů ve výuce fyziky věnovala také souvislosti mezi př́iležitostí učitele a žáků k verbálnímu projevu a fázemi výuky. Fáze se týkají rozdělení činnosti učitele nad předkládaným učivem a s výjimkou fáze shrnutí učiva se ve všech ostatních objevuje výklad či přednáška učitele (viz expoziční žánr v kap. 8.1), a to od 13 \% do 75 \% času z dané fáze. Šed'ová, Švaříček a Šalamounová (2012) uvádí, že výklad s otázkami lze považovat za nejběžnější komunikační formu ve vyučování na druhém stupni základní školy. V rámci jejich výzkumu zahrnujícího 32 zaznamenaných vyučovacích hodin zabírala tato forma 27 \% celkového objemu komunikace ve třídě.

Tyto nálezy odpovídají tomu, že expoziční žánry jako výklad či vysvětlení se zdají být žánry, které se výrazně prosazují v realitě výukové komunikace. Zároveň se domnívám, že jsou nejčastěji zkoumanými žánry mimo dialogickou formu. Přesto se dozvídáme, že „Diskuze o aspektech vysvětlování je doménou především filozofie nebo lingvistiky. Ačkoliv je vysvětlení frekventovanou strategií ve vyučování, pedagogický výzkum se mu zatím věnuje jen okrajově." (Wittwer \& Renkl, 2008, s. 49). 
D. Geelan (2013) identifikoval klíčové prvky vysvětlování učitelů ve výuce fyziky v Austrálii a Kanadě s cílem vytvořit typologii učitelova vysvětlování v daném předmětu, a poskytnout tak materiál k diskuzi vedoucí k větší efektivnosti přírodovědného vyučování. Výzkum probíhal na rozdíl od mého případu na středních školách, ale společným jmenovatelem je kvalitativní analýza videozáznamu výuky se zaměřením na konkrétní žánr. Ačkoliv Geelanova práce přesahuje rámec výukové komunikace reprezentované slovními promluvami, verbální forma tvoří základ pro 5 z celkových 6 identifikovaných hlavních prvků vysvětlování konceptů $\mathrm{v}$ analyzovaných hodinách fyziky. Jedná se přitom o takové prvky, které byly společné všem zkoumaným učitelům. Ve zkoumaných hodinách docházelo k redukci kvalitativních informací na kvantitativní - učitelem komunikované objasňování jevu, případně diskuze se změnily na pouze slovní doprovod k demonstrovaným výpočtům. Dalším identifikovaným aspektem vysvětlování bylo zahrnutí významu učiva nejen pro poznání světa kolem nás, ale především pro budoucnost a úspěch v dalším studiu. Následovaly podpo̊rné strategie pro vysvětlování jevů - používání analogií při výkladu, vyprávění příběhů z dějin přírodních a technických věd, odlehčení humorem a široké využívání technologií ve třídě.

Vysvětlení je podle Leinhardta (2001, in Wittwer, 2008) akcí pedagoga reflektující pokus poskytnout odpovědi na otázky, které jsou položeny explicitně či implicitně. Předkládání vysvětlení, které pouze učitel předpokládá jako vyžádané, ačkoliv nikdo ze třídy nepoložil související otázku, se objevuje také v analyzovaných datech. Především pro tato data platí, že vysvětlení v extenzivní formě učitel poskytoval často na základě reakce na předchozí výpovědi žáků, aniž by se jednalo o položení otázky.

Wittwer a Renkl (2008) vymezují, že vysvětlení má hlavně funkci podpory učení, ale kromě toho má další specifické možnosti využití, které by učitel měl reflektovat. Vysvětlení je možné rozlišit podle toho, jaká je jeho vazba na cíl výuky, zda patří k primární, nebo doplňující strategii ve vyučování a zda je součástí výukových dialogů. Vysvětlení hraje zásadní roli v prvních dvou fázích dosahování dovedností - v rané a střední fázi při představení překládaného konceptu pro základní porozumění, restrukturaci znalostí žáka a podpoře dovedností pro řešení problémů.

Vysvětlování by podle Wittwera a Renkla (2008, s. 51-58) mělo mít následující charakteristiky:

- Adaptace na existující znalosti žáka, jeho zpo̊sobilosti vzhledem ke kognitivnímu vývoji a potřeby jako zásadní aspekt skutečného vysvětlení;

- Zaměření na koncepty a principy jako motivační faktor;

- Integrace probíhajících kognitivních činností žáka jeho aktivním zapojením do vysvětlování namísto pasivní „konzumace“ sdělovaného; 
- Zapojení učitelova vysvětlování ve výuce jen do kontextu, kdy je pro žáky užitečné. Pokud žáci dosáhli poznatků, na kterých mohou dále stavět, je třeba podpořit kreativní produktivitu jejich vlastních idejí a vysvětlení.

Roelle, Múller, Roelle, \& Berthold (2015) spojují efektivitu vysvětlování s jeho integrací do adekvátní učební aktivity. Chybějící uvažování nad tímto aspektem je podle nich příčinou neúspěchu vysvětlování nových poznatků žákům. Vycházejí přitom z taxonomie aktivit podle Chi (2009) vymezující je jako aktivní - konstruktivní - interaktivní. Zatímco zopakování obsahu vysvětlení je aktivní, generování informací, které jsou nad rámec podaného vysvětlení, už patří ke konstruktivní aktivitě. Bez zpětné vazby na vytvořenou konstrukci podobě výukového dialogu však nebude efekt vysvětlení dostatečný, což Roelle et al. (2015) prokázali na základě realizovaných experimentů. Nutno podotknout, že se ve výzkumu orientovali na písemnou formu vysvětlení jevů, tedy zprostředkovanou učebnicí či jiným médiem, ovšem poukazují právě na nutnost propojení textu s výukovým dialogem. Tento aspekt by měl být učiteli rovněž reflektován.

S pojmem žánr se v pedagogické literatuře setkáváme především ve studiích analyzujících přístupy pro rozvoj literární gramotnosti nebo výuku cizích jazyků s důrazem na kontext fungování textů v různých žánrových podobách. Žánrová analýza může být nahlížena ze dvou základních perspektiv - jako reflexe komplexní reality institucionalizované komunikace nebo v aplikační sféře jako efektivní pedagogický nástroj pro výuku jazyků (Bhatia, 2002). Tyto přístupy se opírají o tradiční školy jako tzv. Sydneyská škola, která vychází z Hallidayovy systemické funkční lingvistiky, nebo ESP (English for Specific Purpuses - Angličtina pro specifické účely). $V$ jejich terminologii lze nalézt vymezení žánrů, které vykazuje určitou jednotu, o niž se výzkumník může lépe opřít, když se snaží pojmu žánr porozumět.

Žánr jako pojem odkazuje ke komplexní mluvené reakci mluvčího na požadavek vycházející ze sociálního kontextu komunikace. $V$ dané komunitě jsou tak žánry vnímány jako promluvy patř́ící ke shodnému typu. Žánr je charakterizován komunikačním cílem (případ ně také více možnými cíli, jež spolu souvisejí), přidruženým tématem, textovými konvencemi (struktura, jazykové prvky apod.), typem a rolemi př́ijemců. Základem žánru jsou ovšem cíle, záměry mluvčího, stávají se logickým rámcem pro výběr obsahu a konkrétních prvků sdělení, které odpovídá očekávání př́ijemců v komunikaci (Swales, 1990, Richards et al., 1993 in Abbaszadeh, 2013). Toto pojetí lze aplikovat i na případ žánrů ve výukové komunikaci. Učitel jako hlavní mluvčí sleduje jednotlivé komunikační cíle určené zastřešujícím edukačním cílem vyučovací jednotky, ale i v širší perspektivě rozvoje kompetencí žáků. Tyto cíle se odrazí v použití opakujících se typů promluv učitele ve smyslu 
jednoty textových prvků, které navádí př́íjemce k porozumění cíli i tématu promluvy (např. vysvětlit rozdíly v podnebí dvou kontinentů). Sdělovaný obsah v daném žánru a jeho struktura pak také musí odpovídat očekávání př́ijemců, tedy žáků, a zvyklostem v kontextu komunikace ve školní třídě.

Paralelu k identifikovaným žánrům extenzivních promluv učitele nacházíme v žánrové analýze Bhatiy (in Carstens, 2010). Ve své studii představil hierarchii žánrů, která obsahuje na úrovni řečnických procesů typy žánrů, jako jsou explanace, evaluace a instrukce, a jsou vymezeny na základě komunikačního záměru mluvčího. Změna původního záměru je přitom přirozeným procesem, při němž dochází k promísení nebo vnoření více žánrů navzájem.

Bhatiův hierarchický model a pojetí žánrů opírající se o identifikaci záměru mluvčího, který vybírá pro svou řeč žánr na základě jeho funkce, patří k hlavním inspiracím či podobnostem s tím, jak žánry vnímám rovněž v analyzovaných datech. Funkce je stěžejní rozpoznávací charakteristikou žánru pro autory vycházející z funkční ling vistiky Hallidaye, pro účely zkoumání výukové komunikace ji využil již zmiňovaný Young (1992). Jeho typologie je však úzce zaměřená na otázky učitele, nelze ji tak aplikovat na extenzivní promluvy ve všech formách.

Žánr je pojmenováním pro typ promluv, které mají shodné prvky vnitřní i vnější struktury a jsou identifikovatelné př́ijemcem promluvy na základě rozpoznání komunikační funkce žánru. Jednotícími prvky vnitřní struktury jsou konkrétní jazykové prostředky, které napomáhají př́jemci promluvy, aby se orientoval v záměru sdělení. Vnější struktura žánru je tvořena situačním kontextem promluvy, jemuž musí odpovídat, aby použití žánru promluvy našlo odezvu u příjemce v sociální interakci. V případě žánrů výukové komunikace se jedná o opakující se komunikační situace mezi učitelem a žáky ve školní třídě. V rámci jedné promluvy pak může docházet $\mathrm{k}$ tomu, že se štěpí na více subžánrů z toho důvodu, že záměr mluvčího se v průběhu řeči může měnit. Promluva má však jasnou hranici, je tedy možné zkoumat funkce a tím i žánry pevné formy. Vzhledem k orientaci na extenzivní promluvy učitele aplikuji tuto definici na situaci výukové komunikace mezi učitelem a žáky. Školní třída je základním sociálním kontextem promluv učitele, dále se však kontext zaostřuje na jednotlivé výukové situace. $V$ řeči učitele se tak objevují extenzivní promluvy, jež sledují jeho určitý záměr v těchto situacích a mají typické jazykové prvky odpovídající funkci promluvy a běžné podobě diskurzu v této komunitě. Tím je možné extenzivní promluvy přiřadit k jednotlivým žánrům a vytvořit návrh jejich typologie ve výukové komunikaci. 



\section{$4 /$ \\ SOUČASNÉ VÝZVY VÝZKUMU \\ VÝUKOVÉ KOMUNIKACE}

Od 70. let, kdy se v zahraničí začal rozvíjet výzkum výukové komunikace opírající se o první pokusy zachytit reálná data z prostředí školní třídy, se posunulo jak poznání specifik této komunikace, tak i využití různých přístupů a metodologických strategií. Společnou snahou ve vývoji zkoumání výukové komunikace bylo zachytit reálnou podobu interakcí mezi učitelem a žáky ve třídě a rozšířit výzkumné pole o jejich specifické aspekty a kontex tové proměnné. Zároveň se kromě tradičně využívaných kvantitativně orientovaných výzkumů objevily studie, které si kladly za cíl povahu a funkce řeči ve třídě prozkoumat prostřednictvím kvalitativních metod, případně ve smíšeném designu. Bilance vývoje výzkumu výukové komunikace (Cullen, 1998; Mareš, 2009; Janíková, 2009; Mercer, 2010; Mercer \& Dawes, 2014) ukazuje na zásadní přerod zkoumání komunikace ve třídě z hlediska její vazby na podporu učení žáků a možné proměny komunikace tak, aby strategie učitele odpovídaly požadavkům na dialogické vyučování s aktivizací participace žáků v komunikaci. Diskuze nezbytných změn ve výukové komunikaci je aktuálně součástí především studií zaměřených na výuku přírodovědných předmětů, což souvisí s požadavky současného kurikula v mnoha zemích. Kompetence k řešení problémů jako jedna z klíčových kompetencí, kterou mají žáci dosáhnout, vyžaduje oporu v komunikaci založené na diskuzi a uvolnění tradičních struktur komunikace ve třídě. Mareš v přehledové studii (Mareš, 2009) mapuje základní vývoj zkoumání pedagogické komunikace v českém prostředí od roku 1990 (včetně pozice tématu pedagogické komunikace ve výzkumu ještě před sametovou revolucí). Ukazuje posun výzkumu od dílčích osamocených témat k rozsáhlému týmovému bádání, obohacení teorie o pojmy vycházející z komunikace jako procesu a součásti klimatu třídy a školy. Za dvacet let výzkumů došlo k propojení interakce a komunikace s učivem a pedagogickou koncepcí výuky. K původně dominující kvantitativní metodologii se přidaly 
kvalitativní studie a v posledních letech se často objevují i smíšené výzkumy. I přes značný pokrok také v etablování teorie výukové komunikace, zůstávají pro tuto výzkumnou oblast některé pojmenované výzvy.

První z diskutovaných požadavků, který se váže k mému uvažování nad koncipováním výzkumu, je využívání poznatků ke zkoumanému tématu $\mathrm{z}$ více vědních disciplín. Mareš (2009) dále rozvinul tuto potřebu i směrem k možnosti obnovení multioborových konferencí. Mercer a Dawes (2014) v přehledu vývoje výukové komunikace za posledních 40 let (1970 až 2010) konstatují, že snaha o interdisciplinární přístup se teprve objevuje v dílčích studiích. Pozitivně hod notí současné možnosti pro zachycení autentického datového materiálu, využití množství softwaru a posun v odrazu výzkumných zjištění do změn v edukační realitě. Tedy dokladování vývoje komunikace ve třídě, která by splňovala opakující se požadavky na aplikaci dialogického vyučování. Cestu, kterou musí urazit učitel, pokud je nakloněn porozumět potřebným změnám ve vlastní interakci se žáky směrem k jejich aktivnímu zapojení do komunikace, popisují v našem prostředí Šed'ová et al. (2016). Přenos získaných výzkumných poznatků ve snaze zlepšit reálnou komunikaci ve třídě aplikoval také Thompson (2008). Zaměřoval se na extenzivní promluvy žáků a jejich potenciál ve výukové komunikaci. Do svých zjištění tak následně zapojil učitele z praxe, pro které vytvořil workshopy „na míru“. Rozvoj kompetencí učitelů se však týká také počátku jejich profesní cesty, tedy př́pravy na učitelskou profesi. Tato oblast není dostatečně prozkoumána ve vztahu ke komunikaci studenta učitelství se žáky už během praxe (Mercer \& Dawes, 2014; Viiri \& Saari, 2006).

Stejně tak se pozornost zahraničních výzkumů ve výukové komunikaci intenzivněji zaměřuje na výuku přírodovědných předmětů (Lemke, 1990; Scott et al., 1998, 2006; Mercer, 2002; Lehesvuori, 2013 aj.), často nejen s cílem popsat její reálnou podobu, ale především diskutovat nezbytné změny. Výzkumná zjištění se pak v některých zemích posouvají na úroveň, která zahrnuje iniciativy podporující změny v kurikulu. Př́kladem je vývoj v USA s důrazem na badatelsky orientované vzdělávání především v přírodovědných a technických předmětech, kde jsou žáci vedeni k tomu, aby se zapojovali do diskuze nezbytné pro řešení nastoleného problému, a to při práci ve skupinách (Scott et al., 2006). Podpora efektivních metod při učitelově volbě hromadné formy výuky, kdy pracuje s celou třídou, se odrazila v Británii v důrazu na tzv. dialogické vyučování, přičemž snahy o jeho adaptaci do edukace jsou zastřešovány univerzitními projekty a vzdělávacími institucemi (Myhill, 2006). Efektivněji nastavená komunikace ve smyslu aktivnějšího zapojení žáků do komunikace s učitelem jako facilitátorem učebního procesu žáků se odráží v častějším výskytu extenzivních promluv žákủ ve výuce přírodovědných předmětů (Pimentel \& McNeill, 2013). Lze předpokládat, že tak dojde k eliminaci extenzivních promluv učitele, které pouze poskytují transmisi učiva ve formě 
promluv s nadměrnou informační zátěží. Neznamená to nutně, že se učitel a priori zříká použití extenzivních promluv ve výukové komunikaci, uvažuje však nad jejich kvalitou.

Mezi výzvy, které ale náleží k mnoha jiným disciplínám, patří podle Mercera a Dawese (ibid) zaměření na rozsáhlejší studie. Vzhledem k pokračující tenzi mezi kvalitativní a kvantitativní metodologií ve vztahu k možnostem popsat interakce mezi učitelem a žáky navrhují tito autoři realizovat právě studie velkého měřítka, které by prostřednictvím kvantitativních metod dokázaly určit determinanty efektivní komunikace ve třídě. Tyto determinanty by přitom vzešly z předchozího kvalitativně orientovaného výzkumu. Extenzivita promluv učitele byla doposud zkoumána v některých dílčích aspektech. Spolu s rozsahem promluv celkově (vyjádřeno počtem slov či poměrem vůči žákovským promluvám) i ve vybraných formách a žánrech je možné rozvinout výzkum v problematice kognitivní příznakovosti extenzivních promluv jak učitele, tak i žáků.

Vývoj výukové komunikace od filozofických a metodologických základů po současné výzvy představuje také Myers (2010). Doporučení se týkají odrazu potřeb samotné disciplíny i reality a změn v edukačním procesu. Shrnuje je do dvou hlavních oblastí - rozvoj a zakotvení teorie výukové komunikace a výzkum komunikačních technologií, které podle něj budou značně výuku ovlivňovat. 


\section{5/}

\section{VÝZKUM EXTENZIVNÍCH PROMLUV UČITELE NA 2. STUPNI ZŠ}

Výzkum výukové komunikace věnuje celkově pozornost jak učiteli, tak i žákům. Cílem je obecně porozumět co nejvíce tomu, jak komunikace probíhá, případně vycházet z těchto poznatků při následné práci s učiteli pro zlepšení zjištěného stavu. Téma předkládaného výzkumu, zacíleného na extenzivní řeč učitele a její žánry, vzniklo proto, že bych ráda doplnila stav poznání výukové komunikace o zatím méně reflektované téma, a to jak v českém, tak i v zahraničním prostředí.

Uvažování nad možnostmi, zda a jak z tohoto hlediska zaměřit pozornost na vybranou část promluv učitele, patřilo k první fázi mého výzkumného snažení. Otevíral se přede mnou problém, který lákal k výzkumnému uchopení tím, že zájem o řeč učitele se v posledních letech zaměřoval především na otázky anebo zpětnou vazbu ve výukové komunikaci s úvahami nad podporou změny směrem k dialogickému vyučování. Ve výzkumu řeči učitele však zůstávají bílá místa v podobě analýzy promluv, pro něž jsem dlouho hledala jak pojmenování, tak oporu v dosavadní literatuře. Možnost studovat určitou problematiku více let vedla nakonec k tomu, že pohled na konkrétní promluvy v řeči učitele vykrystalizoval postupně v záměr zkoumat extenzivitu ve vztahu k žánrovým charakteristikám promluv. Nejen pátrání v odborné literatuře, ale i diskuze s kolegy a dalšími odborníky vedly nakonec $\mathrm{k}$ volbě předkládaného výzkumného problému, v němž vidím potenciál pro obohacení dosavadního poznání komunikace učitele ve školní třídě.

Výzkumné téma tedy vnímám jako příležitost nabídnout další „dílek skládačky“ do celkového poznání současné výukové komunikace, která se bude opírat o získaná data reálných vyučovacích hodin na základní škole. Dostupné zdroje (především zahraniční studie) se zmiňují o zkoumání extenzivní řeči a jejího potenciálu, ovšem pouze v komunikaci žáků (Thompson, 2008; Alexander, 2008). Fenomén učitele jako verbálně dominantního aktéra výukové komunikace chci tedy diskutovat z nového 
pohledu, který se soustředí na vybrané segmenty řeči učitele při výuce. Extenzivní promluvy učitele jsou takovým tématem, které je součástí dnes již širokého poznání toho, jak probíhá komunikace ve třídě. Přináší však možnosti nahlédnout na její část, která prozatím zůstala mimo hlavní zájem badatelů. Identifikace ukrytého, prozatím neprobádaného aspektu komunikace není však jediným důvodem, proč by pohled na extenzivní promluvy učitele mohl být zajímavý.

Zájem o zkoumání extenzivní řeči učitele se nabízí proto, že stejně jako další formy řeči, především pak učitelem pokládané otázky ve vyučování, může i extenzivita jako charakteristika učitelových promluv ovlivňovat průběh a kvalitu komunikace. Záměr pohlížet na jednotlivé promluvy v komunikaci může vyvolat zdání, že budou zkoumány jen jako izolovaný jev. To však není možné. Pokud učitel pronáší promluvu, která je delšího rozsahu a sycená množstvím obsažených informací, vždy přitom musí hrát roli, že není ve třídě sám a jeho sdělení jsou motivována edukačními cíli. Propojení úvah nad poznatky z odborné literatury a postřehy z reálné výuky (jak osobními, tak opět prostřednictvím prací, které umožňují čerpat z úryvků $\mathrm{z}$ dat) vyvolalo několik otázek. Studie zahraničních badatelů se vyjadřují k tomu, že extenzivita žákovských promluv je cílovým, žádoucím jevem v komunikaci, znamená to tedy podle teorie příznakovosti, že extenzivní řeč učitele je nežádoucí? Extenzivní řeč žáka je vykročením k dialogu ve výukové komunikaci. Jakou pak může mít funkce extenzivní řeč učitele? A stává se jedním z blokátorů dialogu? Nebo by extenzivita promluv mohla koexistovat na straně učitele i žáka? Jaký je kontext extenzivních promluv z hlediska strukturace výukové komunikace? Jsou extenzivní promluvy učitele reakcí na žákovské výpovědi, nebo vznikají i v jiných situacích komunikace ve třídě? Jedná o projev verbální dominance učitele, a jak se tedy projeví v probíhající komunikaci mezi ním a žáky?

Samotnou extenzivitu je ovšem potřebné detailněji uchopit ve vztahu k možným typům extenzivních promluv učitele. Komunikaci učitele by měly vést edukační cíle, promluvy tak mají splňovat konkrétní funkce. Pokud je v promluvě dokážeme identifikovat, nabízí se možnost zařadit extenzivní promluvy k žánrům, jež vytvoří typologii na základě získaných dat. Jaký je potom vztah extenzivity, identifikovaných žánrů a možnosti reaktivity žáků na tyto učitelovy promluvy? Dostáváme se tak k problému, který vnímám jako stěžejní a je tedy reprezentován hlavní výzkumnou otázkou. Zastřešující, centrální výzkumnou otázkou, která by měla pokrýt pohled na extenzivní promluvy učitele ve vyučování, orientovaný na jejich fungování v žánrech, se ptám:

\section{HVO: Jak fungují žánry extenzivních promluv učitele ve výukové komunikaci?}

Hlavní výzkumná otázka otevřela zkoumaný fenomén, ale v průběhu výzkumu se vyvíjela, vstřebávala postupně zjištění z terénu a následné analýzy dat. Hledání 
odpovědí prostřednictvím odpovídající výzkumné strategie se kromě centrálního fenoménu zaměřilo i na několik podtémat reprezentovaných specifickými výzkumnými otázkami. První z nich pojmenovává potřebu charakterizovat a kategorizovat identifikované extenzivní promluvy učitele, a to na základě funkcí umožňujících přiřadit je k žánrům, případně subžánrům extenzivních promluv.

SVO1: Jaké žánry extenzivních promluv učitele můžeme identifikovat ve výukové komunikaci?

Zájem ve výzkumu se dále orientoval směrem k práci učitele s extenzivními promluvami. Vzhledem k tomu, že data ukazovala významné zastoupení expozičního žánru, tedy nejčastěji se záměrem učitele představit či objasnit jev nebo pojem v učivu, je nutné poznat specificky charakter vnitřní struktury tohoto žánru. Četnost těchto promluv totiž znamená, že učitel by se měl zaměřit na sdělované informace žákům a používané vyjadřovací systémy. Zajímá mě proto, jak konkrétně s tímto žánrem učitel pracuje.

SVO2: Jak naplňuje učitel funkce expozičního žánru extenzivních promluv?

Pokud vnímáme extenzivní promluvy v identifikovaných žánrech a víme, jaké charakteristiky k těmto žánrům patří, je třeba překročit zkoumání promluv jako izolovaných segmentů řeči učitele. Dílčím výzkumným cílem bylo zjistit, jak extenzivní promluvy učitele vstupují do výukové komunikace, a ptala jsem se tedy na to, jaká je provázanost těchto segmentů řeči učitele s předcházející a následnou komunikací ve třídě mezi učitelem a žákem/ žáky, což znamená, jak tyto segmenty na sebe vzájemně reagují. Především jsem se zaměřila na to, jak extenzivní promluvy učitele umožňují žákům zapojit se do probíhající komunikace. Tento aspekt sleduji ovšem ve vztahu k jednotlivým žánrům.

SVO3: Jak se projevuje reaktivita promluv ve vztahu k identifikovaným žánrům?

Extenzivní promluvy budou tedy analyzovány z hlediska jejich žánrového vymezení, a to ve vztahu k provázanosti těchto promluv v komunikační struktuře s důrazem na zjištění, zda podporují žáky k iniciaci v komunikaci nad rámec běžných žákovských replik, které nacházíme na základě př́mé výzvy od učitele.

\section{1}

\section{Design výzkumu}

Kvalitativní výzkum, který jsem zvolila pro hledání odpovědi na výzkumné otázky, odpovídá tomu, že mým záměrem je výzkumný problém prozkoumat, probádat 
a cílem je komplexní, detailní poznání. Design výzkumu, který vychází z volby výzkumného problému a odráží rámcové uspořádání výzkumu (Švaříček \& Šed'ová, 2007, s. 83), může v sobě zahrnovat vliv několika přístupů, které napomáhají nalézt odpovědi na otázky, které si výzkumník od první fáze klade. Mercerova přehledová studie (2010) inspirující výzkumníka v možnostech, jak uchopit rámec své práce při zkoumání komunikace ve třídě, odkazuje na dva hlavní proudy ve Velké Británii, kde má výzkum výukové komunikace dlouhou tradici.

Prvním z tradičních přístupů pro výzkum komunikace ve třídě je lingvistická etnografie. Studie jsou typicky založené na pozorování v rámci kvalitativního designu a zahrnují detailní analýzu školní řeči v jejím sociálním a kulturním kontextu. Druhým z vlivných přístupů je pak sociokulturní rámec vycházející z prací Vygotského nebo Alexandera (ibid). Zdůrazňují vliv jazyka na rozvoj myšlení žáků a učitel se tak objevuje v zorném poli výzkumníka jako hlavní postava zprostředkování tohoto vlivu. Zkoumání komunikace ve tř́dě se pak může opírat o diskurzní analýzu se zaměřením na jazyk aktérů (v psané i mluvené podobě) a jeho organizaci do struktury přesahující základní jednotky, jakými jsou věty. Sinclair a Coulthard (1975 in Mareš, 2016) takto vytvořili metodu pro kategorizaci veškeré řeči ve třídě do hierarchického systému a v mnoha následujících studiích odkazovali a stále odkazují další autoři na jejich strukturu výměn IRF.

Mezi zástupci zmíněných př́stupů nastává přitom konsenzus v tom, že porozumění školní edukaci se neobejde bez důkladného poznání povahy a funkce řeči ve škole/ tř́dě, což předpokládá kvalitativní analýzu zkoumaného (Mercer, 2010).

Tento text je ovlivněn dvěma přístupy, lingvistickou etnografií a diskurzní analýzou komunikace, které propojuje pohled na jazyk, jež nechceme zkoumat jen jako abstraktní model existující ve vakuu, ale jazyk a řeč ve specifickém kontextu (Johnstone \& Marcellino, 2010). Lingvistika se zabývá studiem jazyka v sociokulturním kontextu s cílem odhalit jeho strukturu. Propojení lingvistické analýzy jazyka a sociokulturního rámce znamenalo rozvoj lingvistické antropologie a dalších disciplín, které těží z interdisciplinárního přístupu. Dynamiku vztahu mezi lingvistikou a etnografií odráží etnografie komunikace, která se stala silným proudem vlivem práce Dell Hymese (Rampton, Maybin \& Roberts, 2014).

Diskurzní analýza komunikace ve tř́dě vychází z obecnějšího pojetí diskurzu jako užívání jazyka. Cílem je zjistit a interpretovat informace o tom, jakým způsobem subjekty pomocí jazyka utvářejí smysl a význam (Newby, 2014). Zatímco jazyk samotný může být podle lingvistů i dekontextualizovaný, diskurzní analýzou se snažíme zjistit, jak je toto užívání ovlivněno kontextem. $V$ př́ípadě třídy může kontext zahrnovat množství jevů - od výukových promluv po vše, čím prochází žák během socializace, a tento rámec přesahuje jazyk vázaný přímo na kontext třídy. Rymesová (2009) vymezuje tři základní dimenze kontextu třídy. Sociální kontext 
a vzájemný vliv na užití jazyka odkazuje na práci Hallidaye (1975), Rymesová tak vymezuje funkce jazyka v komunikaci mezi učitelem a žáky v různých kontextech. Proměna funkce jazyka v užití podle aktuálně vnímaného kontextu je dokládána odlišnými reakcemi komunikantů. Totožná otázka je tak identifikována a zodpovězena různě. Pro tento výzkum je však inspirativní především interakční kontext. V této dimenzi překládá Rymesová teorii o předpokládaných a neočekávaných interakcích. V tradiční výuce (frontální výuka bez využití moderních didaktických strategií) stejně jako v konverzaci vidíme tendenci držet se předpokládaného scénáře. Interpretace interakcí učitelem rozhoduje o podobě komunikace ve třídě, konkrétně pak kupř́kladu o tom, jaká bude reakce učitele na vstup žáka do komunikace v případech, které dále předkládám a kde učitelé vybočení z předpokládaných interakcí neočekávají.

\section{2}

\section{Výzkumný vzorek}

Ve výzkumu extenzivních promluv učitele s cílem poznat jejich povahu a místo ve výukové komunikaci nevycházím z náhodně vybraného reprezentativního vzorku učitelů základních škol. Učitele zahrnuté do tohoto šetření jsem vybírala postupně, jak se prolínaly fáze v terénu již s první analýzou doposud získaných dat. Tento postup je v kvalitativním výzkumu běžně realizovaným principem postupného vzorkování (Strauss \& Corbin, 1999). V některých případech jsem použila pro získání dalších učitelů metodu sněhové koule. Její podstatou je oslovit participanty, kteří jsou již pevnou součástí vzorku, s otázkou: $\mathrm{S}$ kým bych měl mluvit/ koho pozorovat? Kdo by mi mohl říct/ukázat více o...? (Patton, 2002). Takto jsem mohla na jedné ze základních škol rozšírit počet učitelů z původních dvou zapojených na celkem 5 participantů. Jednoho z nich jsem ale násled ně musela vyloučit, ukázalo se totiž, že se předcházející učitelé rozhodli upozornit mě na tohoto učitele, abych jim jako „člověk z venku“ potvrdila některé jejich teze o (ne)kvalitě jeho výuky. Celkový tlak některých kolegů pak způsobil, že učitel ze školy odešel.

Výzkumné šetření zahrnuje šest učitelů působících na prvním i druhém stupni základní školy, přičemž konkrétní pozorované vyučovací hodiny se vždy ale týkaly jen výuky od 6. do 9. ročníku, tedy na takovém stupni vzdělávání, kde bychom předpokládali především zastoupení dialogických forem výukové komunikace bez přemíry izolovanějších extenzivních promluv.

Prvním zkoumaným učitelem se stal učitel Adam ze zprostředkovaného datového materiálu (viz kap. 6.5.1). Přesto jsem se snažila získat co nejvíce informací jak o něm samotném, tak i o škole, kde působil. $V$ době záznamu výuky patřil Adam 
k začínajícím učitelům na jedné ze středně velkých pražských základních škol. Přestože pracoval na škole teprve krátce, stal se ve školním roce, kdy probíhal výzkum, trrídním učitelem $\mathrm{v} 6$. třídě, kde stejně jako v dalších ročnících vyučoval český jazyk. Na dané škole, která spolupracuje na praxích studentů Pedagogické fakulty UK a zapojuje se do mnoha dílčích projektů, už tento učitel aktuálně nepůsobí.

Hledání učitelů, jejichž výuku už bych mohla sama přímo pozorovat a zároveň snímat na videokameru, posléze začalo ve Zlínském kraji, kde bylo pravděpodobnější, že na základě pracovních vztahů získám mezi učiteli na školách partnery pro výzkum, kteří mi budou důvěřovat. Záměrem přitom nebylo vyhledávat učitele podle předem nastaveného kritéria. Spolupráce na projektu s několika základními školami mi otevřela dveře i do jedné z této škol a následně do tříd dvou učitelek.

První sběr dat proběhl ve výuce učitelky Dany, která patřila ke zkušeným učitelům s praxí přes 30 let. Její komunikace se žáky i kolegy byla velmi energická a spontánní, což se odráží i ve stylu komunikace přímo ve výuce. Vyznačovala se skutečně osobitým projevem („...já tady lítám jak hňup po tř́dě...", „....když si zblblý sexem, nepřemýšlíš, vališs..."). Podle svých slov se těšila do důchodu, ačkoliv navenek nepůsobila dojmem, že by už pauzu od školy potřebovala, a v současné době stále na škole působí jako vyučující prrírodopisu, chemie a tělesné výchovy, kam si chodí odpočinout od „učení mezi čtyřma stěnama“. Během sběru dat, který trval do konce května, jsem trávila přestávky mezi hodinami a další dobu čekání na domluvené pozorování v kabinetu právě této učitelky, a tak se stala největším zdrojem informací o chodu školy a dalších učitelích. S učitelkou Danou jsme se postupně dohodly na pozorování pěti vyučovacích hodin, z nichž první jsem nakonec do vzorku nezahrnula kvůli technickým potížím při zaznamenávání na videokameru.

Druhou učitelkou ze zlínské školy, která souhlasila ve stejné době s účastí na výzkumu, byla blízká kolegyně Dany, rovněž s velmi energickým vystupováním především vůči žákům ve výuce i při dozoru na chodbách. Při rozhovorech ale působila rezervovaně, nebyla spokojená s chováním žáků na hodinách při pozorování, což se odrazilo na větší nervozitě, která se ale v jejím projevu objevila vždy až po skončení vyučovací hodiny. Učitelka Adéla už patří také ke zkušeným učitelům, měla v době sběru dat 26 let praxe a stejně jako Dana je stále třídní učitelkou jedné ze tříd, kterou jsem sledovala.

Soubor čtyř pozorovaných vyučovacích hodin u každé z učitelek se při analýze transkribovaných dat jevil jako dostatečný pro poznání komunikačního jednání učitele, které se zásadně neměnilo v odlišných tř́dách nebo předmětech. Stanovila jsem si tak tento počet hodin jako minimální pro následující sběr dat. Se zapojením dalších dvou učitelů mi pomáhaly učitelky Dana a Adéla, reflektovaly práci kolegů, zapojily se tak do výběru, přičemž se shodly na dvou učitelích, jejichž profesní 
kompetence hodnotily velmi pozitivně, a tak jsem mohla vstoupit do tříd učitelů Jakuba a Evy.

Učitelka Eva měla v tomto roce 10 let praxe a její přístup k žákům byl velmi silně ovlivněn tím, že na 2. stupni vyučovala pouze český jazyk v 9. třídě. Aprobaci měla ale pro výuku na 1. stupni a zřejmě proto se v jejím komunikačním projevu objevovala neustálá slova chvály („Výborně.“, „Šikulky“ atd.). Na rozdíl od jejích kolegů, kteří trávili čas ve třídách jen na 2. stupni, si do 9. třídy „chodila odpočinout, protože s těma devátákama je to někdy náročné, ale dá se s nimi zase bavit o jiných tématech než s těmi malými. "Dana s Adélou mi prozradily, že když mají během výuky Evy volno, je v jejich kabinetu naprosté ticho, aby slyšely její výklad ze sousedící třídy přes dveře, protože „tak jako ona to nikdo neumí podat, to se prostě nádherně poslouchá a ještě se něco dozvíme.".

Učitel Jakub u kolegyň nevyvolával tak bezprostřední nadšení, byl nejmladším zkoumaným učitelem s osmiletou praxí. Pozorování jeho hodin také předcházelo doporučení starších kolegyň Dany a Adély, i když bez konkrétnější specifikace, spíše se zdálo, že obě dobře hodnotí, že si na hodinách dokáže sjednat kázeň žáků. Jakub působil lehce flegmaticky, a to jak ve výuce, tak i mimo ni. Možná také proto na škole už dnes nepůsobí. Pozorováním komunikace ve třídě, kde vyučoval Jakub, skončil sběr dat na dané zlínské škole. Získala jsem tam postupně 4 učitele různých předmětů a nechtěla jsem, aby další data pocházela ze stejného prostředí.

Pátrání po dalším možném učiteli, který by se stal součástí tohoto výzkumu, jsem záměrně přesunula za hranice Zínského kraje. Vzorek jsem tak nakonec doplnila o učitele z brněnské základní školy. Cíleně ve snaze neodlišit výběr na úrovni typu školy, zvolila jsem opět běžnou větší základní školu (tzn. s počtem nad 500 žáků) s poměrně stabilním učitelským sborem a snahou zapojit školu do projektů výhodných jak pro žáky, tak pro rozvoj školy. Specifikem posledního pozorovaného učitele, Martina, byla jeho pozice ředitele této školy. Pozitivem pak byla nejen ochota zapojit se do výzkumu, ale také probrat se mnou před začátkem sběru dat z výuky vše, co mě zajímalo. Podobně jako si učitelka Eva chodila odpočinout do 9. třídy od rutinnější práce s mladšími žáky, tak i Martin byl vděčný za přetrvávající výuku fyziky v 6. ročnících, aby jeho práce nezůstala už jen u administrativy. Záznamy výuky tohoto učitele se staly zajímavým materiálem pro analýzu také proto, že jsem měla k dispozici nahrávky stejného obsahu vyučování pro dvě různé třídy. Během výuky v jeho třídách jsem vnímala určitou snahu dobře se navenek prezentovat, což se konkrétně projevilo kupříkladu tím, že v různých třídách opakoval totožná vtipná sdělení, která měla přitom v žácích vzbudit dojem, že ho teprve ted' napadla. Učitel cíleně opakoval konkrétní formulace, pokud se setkaly s příznivou odezvou u žáků v jedné ze tříd. Sběr dat u učitele Martina proběhl už ve fázi, kdy data od předchozích učitelů prošla analýzou. Tento posun se projevil 
v užším zaměření terénních poznámek, s uvědoměním, že sledované vyučovací hodiny Martina potvrzují dosavadní zjištění, nálezy se opakují a vzorek se stane nasyceným.

Kvalitativní výzkumná strategie vyžaduje, aby se výzkumník zamýšlel nejen nad tím, koho vybere do vzorku, ale také nad tím, kde a kdy bude sběr dat probíhat (Hammersley \& Atkinson, 1995 in Bloor \& Wood, 2006). Jak uvádím v následující tabulce, snažila jsem se do vzorku zahrnout jak humanitně, tak i přírodovědně orientované předměty, a to ve všech ročnících druhého stupně základní školy. První výzkumná data učitele Adama pocházela z hodin českého jazyka, takže následný sběr dat ve výuce učitelek Adély a Dany měl také ukázat na to, zda data z př́rodovědných předmětů budou rovněž nosná pro výzkum extenzivních promluv učitele. Při prezentaci záměru mého výzkumu na konferencích, které mi poskytovaly průběžnou zpětnou vazbu, jsem se setkávala často s dotazem, zda přírodovědné předměty nejsou zahrnuty zbytečně, protože lze předpokládat, že u humanitních předmětů je tematicky i didakticky větší předpoklad pro extenzivní promluvy učitele. Data z př́rodovědných předmětů však nevykazovala rozdíly ve výskytu extenzivních promluv učitele, ani ve stanovených charakteristikách těchto promluv (viz kap. 7.1), proto jsem se rozhodla, že vzorek nebudu zužovat pouze na vybranou oblast humanitních či prŕrodovědných předmětů. Snažila jsem se spíše vybírat i mezi možnými participanty z řad učitelů tak, aby vzorek dat byl konzistentní v poměru obou oblastí. Vzhledem k tomu, že stejně tak nebyl patrný ani významný rozdíl v datech získaných $\mathrm{v}$ jednotlivých ročních 6 . až 9. tř́́dy, tak jsem se i v tomto případě rozhodla nezužovat výzkumný vzorek výběrem některých z nich.

Sběr dat zároveň probíhal $v$ různých fázích školního roku, kdy jsem mohla předpokládat zastoupení vyučovacích hodin jak s výkladem nových témat, tak i hodiny zaměřené více na opakování učiva.

Tab. 1 Přehledová tabulka pozorování u jednotlivých učitelů

\begin{tabular}{c|c|c|c} 
Učitel & Počet videozáznamů & Vyučovací předměty & Ročník \\
\hline Adam & 4 & český jazyk & $6 ., 7 ., 8$. \\
\hline Adéla & 4 & zeměpis, matematika & $7 ., 8 ., 9$. \\
\hline Dana & 4 & př́rodopis, chemie, matematika & $6 ., 8$. \\
\hline Jakub & 4 & dějepis, výchova k občanství & $8 ., 9$. \\
\hline Eva & 4 & český jazyk & 9. \\
\hline Martin & 4 & fyzika & 6. \\
\hline
\end{tabular}




\section{3}

Fáze a metody sběru dat

Sběr dat probíhal postupně v několika fázích s cílem dosáhnout nasycenosti závěrů.

\section{3 .1}

\section{Nepřímé pozorování}

První fáze sběru dat proběhla na základě nepřímého pozorování komunikace učitele a žáka ve tř́́dě. Prvním zdrojem dat tak byly 4 videozáznamy vyučovacích hodin z jedné pražské základní školy, které pocházejí z výzkumu realizovaného Univerzitou v Hradci Králové, a za jejichž poskytnutí děkuji. Získala jsem tak záznamy výuky českého jazyka učitele Adama. Nalézt základní školy a učitele ochotné zúčastnit se výzkumu za použití videokamery trvalo přibližně půl roku, proto jsem si během této pátrací doby chtěla již za pomoci reálně zachycených dat „ot’ukat“ terén ze současné školy. Tyto záznamy mi sloužily především k prvotnímu ověření, zda lze pro výzkumný problém nalézt relevantní data, což se nejenom potvrdilo, ale také byla tato data velmi zajímavým materiálem i pro další fáze výzkumu.

V celkovém pohledu na data získaná prostřednictvím pozorování, se tato první část z nich lišila tím, že neposkytovala výhody participačního pozorování včetně neformálních rozhovorů s učitelem Adamem (viz dále 6.5.4). Použití dat sebraných během předchozích výzkumů se ovšem v některých případech využívá, a to jak ve fázi sběru dat (např. Syslová \& Horňáčková, 2014) nebo při analýze a interpretaci dat (např. Šalamounová, 2015).

\section{3 .2}

\section{Zúčastněné pozorování}

Zúčastněné pozorování představovalo prvotní, ale intenzivní fázi vnímání daného prostře dí. Výzkumník může být při pozorování vtažen přímo do děje, ale také může zůstat $\mathrm{v}$ roli pozorovatele, což byla konkrétně má volba v průběhu vyučovacích hodin. S učiteli, žáky a v jednom případě i asistentkou žáka jsem byla v kontaktu jen v čase mimo výuku, o přestávkách, cestou ze školy. Při pozorování jsem získala data ve dvou podobách.

Bezprostředním datovým materiálem z pozorování se staly terénní poznámky, zpočátku spíše obecně laděné, s odrazem snahy zachytit vše, co by následně mohlo být přínosem pro odpovědi na výzkumné otázky, ale ještě bez selekce vybraných 
jevů. Od počátečního seznamování se s terénem se přímé pozorování postupně stávalo zacíleným a zcela volné poznámky z terénu se přetavovaly do konkrétnějších postřehů výzkumníka zaměřených na extenzivní promluvy učitele. Analýza terénních poznámek tak podpořila tvorbu konceptu jednoho z vnímaných faktorů extenzivity učitelových promluv. Konkrétně totiž ukázala na výrazný vliv komunikačního stylu učitele.

Pro detailní zachycení extenzivních promluv učitele v kontextu komunikace ve tř́́dě by samotné poznámky pozorovatele nebyly dostatečné. Jedinec nemůže zvládnout sledovat a zachytit všechny události, proto jsem využila k jejich záznamu videokameru. Výhodou zachycení pozorovaného použitím videokamery je přesný záznam všech jevů probíhajících v konkrétní vyučovací hodině. Videozáznamy výuky jsou tak reprezentací učitele „, akci“, kterou neovlivní otázky výzkumníka, učitel je v danou chvíli ve svém prostředí a musí jednat. (Creswell, 2007). Tento stěžejní datový materiál zahrnuje celkem 24 videozáznamů výuky u 6 učitelů na 3 běžných základních školách nacházejících se v krajských městech České republiky. (Přesné rozložení vyučovacích hodin zprostředkovává tab. 1.) Původní materiál obsahoval ještě další 2 hodiny, které však nebyly zahrnuty do analýzy dat. Jedna z hodin byla zkušební verzí, př̀ které nebyl záznam dostatečně kvalitní, druhá potom zachycovala učitele, který před uskutečněním dalšího pozorování z dané školy odešel.

Data v podobě terénních poznámek i videozáznamů byla pečlivě transkribována do textového formátu, který je základem pro další analytickou práci s daty. V mnoha př́padech ale záznam výuky na videu umožňoval vracet se k zachyceným jevům a porozumět tak lépe daným interakcím tehdy, když v transkripci textu chyběly detaily dění ve třídě objasňující kontext komunikace.

\section{3 .3 \\ Přítomnost výzkumníka v terénu}

Stát se pozorovaným může vyvolat u participantů rozpaky či obavy, především pokud získají pocit, že pozorování vede k určitému hodnocení jejich jednání. Rizikem každého vstupu do terénu je tak reaktivita sledovaných osob (Patton, 2002), která mohla nepř́íznivě ovlivnit získaný datový materiál. Učitelé, na něž mířila videokamera i pohled výzkumníka, se k účasti na výzkumu rozhodovali velmi rychle, aniž by vyjadřovali obavy nebo se ptali na detaily toho, co se následně může objevit zveřejněné. Především učitelky Dana a Adéla se k natáčení stavěly jako k nevýznamné události, která pro ně navíc není novou situací. "Já když tam ta kamera je, tak možná chvilku teda si toho všímám, ale tak za pět minut už to prostě 
nevnímám a je mi to jedno. Učím a hotovo."Koneckonců už pozorování jejich hodin ještě před analýzou transkribovaných záznamů naznačovaly, že si skutečně nedělají starosti s tím, jak jejich komunikace může působit. Projev učitelů vnímám jako přirozený, opakující se ve všech zaznamenaných hodinách, bez známek kontroly nad výukou zachycenou na kameře. Rozpor ale nacházím mezi vyjádřením jiné učitelky, Evy, která také mluvila o tom, že snímání výuky na videokameru jí nečiní obtíže (a dokonce sama nabízela, že bych mohla kdykoliv natočit i její výuku na 1. stupni dané základní školy), a jejím následným napomenutím žáků ve třídě. „Děcka, to ale neznamená, že je něco jiného dneska v hodině, že vy se budete chovat, jako kdybychom se nikdy neučili, právě naopak. "Sděluje tím, že si uvědomuje odlišné chování žáků, kteří seděli v lavicích blízko videokamery, a posledním dovětkem „právě naopak“ také př́ní, aby hodina dopadla pro oko kamery lépe než jindy. Zde je tedy potřeba, aby výzkumník takové momenty $\mathrm{v}$ datech zachytil a interpretoval s přihlédnutím k odlišnosti komunikačního chování pozorovaných osob. Při analýze extenzivních promluv učitele jsem pak ale nezaznamenala verbálně či neverbálně projevenou reaktivitu, která se vztahovala př́mo k nim.

\section{3 .4}

\section{Nestrukturované rozhovory s učiteli}

Součástí datového materiálu se staly také nestrukturované rozhovory s učiteli, ale i jejich kolegy, kteří byli prrítomni našim rozhovorům před nebo po pozorované vyučovací hodině. Neformální interview je využíváno k tomu, aby prostřednictvím méně řízené formy interview, spíše „kontrolované konverzace“, umožnilo výzkumníkovi nahlédnout více pod povrch zkoumané tématiky. Participanti výzkumu cítí větší volnost pro vyjádření, nacházejí se také obvykle v prostředí, které je jim př́jemné. Neformální rozhovory nejsou strukturované, otázky se vynořují obvykle přirozeně prrímo v procesu dotazování (Jamshed, 2014).

Do škol jsem na natáčení přicházela vždy s předstihem, často jsem strávila ve škole čas mezi 1. a 5. vyučovací hodinou a využila ho právě $\mathrm{k}$ hovorům s učiteli školy. Bezprostřední iniciace k rozhovoru byla přitom vyvolána většinou samotnými učiteli, kteří chtěli znát mé postřehy k proběhlé hodině, nebo přispěchali s komentářem k dění ve tř́ídě, které se snažili osvětlit, aby možná „poupravili“ můj dojem a interpretaci záznamu výuky.

Učitelé nebyli předem seznámeni se záměrem zkoumat v rámci výukové komunikace jejich jednotlivé promluvy, aby se na tento aspekt $v$ hodinách nesoustředili. Vymezení zájmu obecně o komunikaci ve třídě pro ně bylo dostatečné. Po ukončení sběru dat $v$ jejich hodinách jsem pak ale toto téma v rozhovoru otevřela. Ukazovalo 
se zde obecné přesvědčení o tom, že v jejich výuce byly extenzivní pasáže spíše ojedinělé.

Data získaná prostřednictvím neformálních interview s učiteli dokreslovala analyzované vyjadřovací prostředky učitele. Vzhledem k tomu, jak se vyvíjely výzkumné otázky, zaostřovaly se až v rozhovorech s učiteli Evou a Martinem otázky k extenzivním promluvám. Nejedná se však z hlediska významnosti o primární data pro výzkum, rozhovory probíhaly v době, kdy jsem ještě neuvažovala do hloubky nad žánrovými charakteristikami promluv učitelů. Bylo však zajímavé sledovat, jak o žácích a své roli mluví za zavřenými dveřmi třídy, zda a jak se proměňuje styl komunikace vůči jiným osobám, než jsou žáci. Učitelka Dana stejně jako učitel Martin zůstávali stejně naladěni ve třídě i mimo ni. Dana se mnou během našich setkání mluvila zcela bezprostředně o všem, co v těch dnech prožívala, a to nejen o škole. Martin se snažil působit na okolí zajímavě, týkalo se to třídy, ale i jeho interakcí se mnou či kolegy ve škole. Oproti tomu učitelka Adéla zůstávala rezervovaná a přísná, při rozhovorech s ní jsem se nemohla zbavit pocitu, že jsem opět žačkou na základní škole. Ve všech případech se ovšem jednalo vždy o učitele, kteří vyjadřovali spokojenost s tím, jak se jim v učitelské práci daří.

\section{4}

\section{Analýza dat}

Analýza dat v souladu se zvolenou kvalitativní strategií byla postavena na zpracování dat v plném rozsahu. Kódování datového materiálu přitom přinášelo nový pohled na získaná data, která se tím vlastně rozšiřovala o vznikající interpretace. Transformace objemného datového materiálu byla výzvou, kterou jsem začala výchozím bodem Creswellovy spirály, představující model procesu analýzy dat (2007, s. 151) - organizací dat na segmenty, které jsem podrobila detailní analýze.

Analýza dat probíhala na dvou základních úrovních: učitelovy promluvy kontext učitelových promluv se zaměřením na reakce žáků. Vzhledem k tématu mě z transkribovaných vyučovacích hodin zajímaly především promluvy učitele, které jsem identifikovala jako extenzivní. Kritéria výběru uvádím dále v kap. 7.1. Tyto segmenty dat jsem zkoumala nejdříve izolovaně, v dalším kroku jsem již analyzovala i ostatní části výuky v dané hodině, abych zachytila kontext promluv učitele. Prvotní volbou pro analýzu dat, bylo otevřené kódování, které můžeme považovat za obvyklé východisko v kvalitativním výzkumu.

Kódování datového materiálu probíhalo cyklicky. K analyzovaným transkriptům jsem se vracela vždy znovu jak s přibývajícími daty, tak i v případě, že se z nich vynořila myšlenka, která vyžadovala nový náhled. Některé kódy jsem úplně opustila, 
jiné se zpřesňovaly, a tento dynamický postup je při otevřeném kódování běžný (Miles, Huberman \& Saldana, 2014). Během postupné analýzy datového materiálu tak vzniklo množství kódů, které jako základní jednotky analýzy zachytily zjištění $\mathrm{z}$ dat na nejnižší úrovni abstrakce.

Při zkoumání jednotlivých kódů ve fázi, kdy jsem pracovala s datovým materiálem již od tří učitelů, vznikaly v následném procesu první koncepty, které se vynořovaly právě $\mathrm{z}$ kódů. Také koncepty následně podléhaly opakovanému procesu doplňování a zpřesňování, zejména prostřednictvím postupu konstantní komparace.

Analytický postup konstantní komparace vychází z metod zakotvené teorie, jak je od původního modelu rozvinula Charmazová (2006, in Švaříček et al., 2012, s. 223). Jak název techniky napovídá, probíhala i v tomto případě postupně na všech rovinách práce s daty, nejen při otevřeném kódování, ale i v následných fázích analýzy dat. $V$ souladu s principem konstantní komparace spočíval tento krok v porovnávání jednotlivých zkoumaných případů.

S dalším pozorovaným učitelem, a tím i novými daty, obvykle přišly kódy, které vedly k odhalení nového konceptu. Ten byl následně ověřován i u předchozích, již analyzovaných učitelů. Shody a rozdíly u všech hodin jednotlivých učitelů vyústily nakonec $\mathrm{v}$ typologii komunikačních stylů vázaných na extenzivní promluvy učitele. Platilo, že pro každého učitele jsou zde jisté prvky, které mají společné, ale zároveň takové projevy v komunikaci při extenzivních promluvách, které jsou kostrou daného stylu.

Každý výzkum se v určité fázi dostane do bodu, kdy je nezbytné zaměřit se na tvorbu konceptů a kategorií jako zásadních jednotek analýzy dat. Reflexe vztahu kódů ke konceptům a kategoriím probíhala přitom již v začátcích analytického procesu. Postupně také bylo třeba uvažovat nad tím, jak se vznikající kategorie vztahují k dalším myšlenkám vycházejícím z dat a vytváří tak preciznější kategorie (Richards, 2009, s. 94).

Analytická a sebereflektivní mema jako součást procesu analýzy dat umožnila komentovat datový materiál způsobem, který napomohl extrahovat významy $\mathrm{z}$ dat. Zaznamenávat myšlenky, které později budou užitečné, jakmile analýza dat postupovala k finálním krokům. Mema měla obvykle podobu otázek nebo kratších narací (Miles et al., 2014) zachycených přemítáním nad daty a reflektující procesy uvažování. Sebereflektivní mema pak dokumentovala osobní postřehy k pozorovanému (Creswell, 2007).

Mema se jako součást analýzy dat objevila také při pozorování posledních dvou učitelů. $V$ té době jsem už podrobovala analýze množství dat z předchozích transkribovaných vyučovacích hodin a při zaměřeném pozorování učitelů Evy a Martina jsem neustále přepínala mezi terénními záznamy a postřehy, které se 
vynořovaly spojením předchozích zjištění s aktualizací vnímání těchto idejí přímo ve zkoumaném prostředí.

Kromě mem v průběhu pozorování vznikaly postřehy, komentáře a náznaky interpretace jak nad jednotlivými segmenty dat, tak kupříkladu i k celé vyučovací hodině nebo všemu, co do daného okamžiku data ukazovala. Takto jsem se v průběhu analýzy vracela také ke vstřebanému dojmu z práce na transkriptu vyučovací hodiny učitele Jakuba:

„Struktura trochu poházená, od jednoho tématu ještě sám skočí na jiné. Jiná situace by nastala, kdyby to bylo na popud žáků nebo při zjištění, že tomu nerozumí, nepamatují si a podobně. Identifikace tématu je usnadňována zápisem na tabuli - klíčová slova = celá témata. Souvislosti mezi nimi ale váznou. Uvede prostě, že ke schopnostem řadíme inteligenci. Ale proč? Sám pořád komentuje, jak se nebudou zdržovat, jak si rychle nasázejí pár definic. Zdržovat se by byla ztráta času? Žáci se dostanou v této hodině ke slovu více než jinde, ale jsou to jenom rychlé komentáře a pokusy o odpovědi, pokud se učitel vưbec ptá. Hodina určená tím, že učitel ji staví na definicích pojmů, které postupně přibývají na tabuli."..

\section{5}

\section{Kvalita výzkumu}

Inspirací k volbě strategie pro potvrzení validity výzkumu bylo množství možných perspektiv, které se dnes výzkumníkovi nabízí (viz Denzin \&Lincoln, 2005; Creswell, 2007 aj.).

Indikátory kvality vypracované v National Centre for Social Research in the UK mají podobu čtyř základních principů, které jsou dále rozvedeny do 18 posuzovacích otázek. Cílem bylo prezentovat určitý rámec kvality, který by nebyl zároveň příliš úzkým modelem omezujícím kvalitativní výzkum. Tento rámec poskytuje určité vodítko začínajícím výzkumníkům a zároveň možnost vrátit se v závěru výzkumného šetření k celému procesu tak, aby v odborné komunitě mohl působit přesvědčivě (Newby, 2014). Hodnotící otázky tohoto rámce s důrazem na doporučené indikátory 8-12 (Newby, ibid, s. 461-462) jsem si prošla a zodpověděla.

Různé přístupy ke kvalitě jsou shodně protkány požadavkem na důvěryhodnost předkládaných tezí. Vzhledem k tomu, že se badatel především v etnografickém výzkumu snaží ponořit co nejhlouběji do studované reality, při analýze a interpretaci dat je užitečné využít techniku zapojení reflexe kolegů (Creswell, 2007). Tato strategie se ukázala jako velmi př́ńnosná. Měla jsem příležitost aktuální data a jejich možnou interpretaci pravidelně reflektovat se dvěma kolegy, jejichž nadhled 
a otázky vždy lépe zacílily mé zkoumání. Rovněž opakovaná prezentace tématu výzkumu a postupných zjištění na konferencích s měnícím se odborným publikem umožňuje zachytit $v$ průběhu práce zpětnou vazbu $v$ dané komunitě. $K$ tématu a výzkumným zjištěním vznikaly také dílčí výzkumné zprávy, jejichž recenze poukazovaly na sporné či chybějící aspekty. Výzkumník by měl také reflektovat limity svého výzkumu. Ty, které vnímám, předkládám v závěru.

K validitě kvalitativní studie přispívá také zařazení adekvátních citací z dat dokládajících popsané nálezy a jejich interpretaci (Richards, 2009, s. 199). Následující kapitoly, kdy se snažím popsat cestu po stopách učitelových extenzivních promluv ve vyučování, obsahují tak příklady ze zachycených dat. Použití videokamery pro záznam hodin mi umožnilo vracet se $\mathrm{k}$ nim opakovaně v průběhu celé práce $\mathrm{a}$ jsou také trvale archivovány.

Důvěryhodnost jako kritérium validity je podpořena konsistencí metod pro vytvoření důvěryhodného výstupu (Richards, 2009). Nad rámec zajištění validity však může výzkumník použít triangulační koncept pro podpoření poznatků získáním dalších informací (Flick, 2004 in Švaříček et al., 2007, s. 204). Spolehlivost tohoto výzkumu je posílena triangulací metod sběru dat, kdy jsem mohla dále porovnávat terénní poznámky s transkripcí videozáznamů a doplněním o rozhovory s učiteli. Zmíněná transkripce byla pak provedena tak, aby splňovala principy autenticity (záznam přibližující co nejlépe originální interakci) a praktičnosti - respektování jednotného způsobu přepisu pro všechna data, přehlednost záznamu (Bloor \& Wood, 2006). Ačkoliv existují možnosti pro transkripci dat pomocí speciálních programů (Janík \& Miková, 2006), upřednostnila jsem klasickou techniku přepisu do textové podoby a domnívám se, že přitom nedošlo k redukci dat.

Kniha se zaměřuje na detailní prozkoumání extenzivních promluv šesti učitelů a celkově jejich práce ve 24 vyučovacích hodinách. Není tedy možné uvažovat o zobecnitelnosti zjištění, což ani nemohlo patřit k cílům tohoto výzkumu. Pojítkem následně odkrývaných aspektů extenzivní řeči učitele jsou však prvky, které byly společné zkoumaným učitelům. Můžeme se tedy domnívat, že bychom je objevili i v dalších případech.

\section{6}

\section{Etika výzkumu}

Už během plánování kvalitativní studie si musí výzkumník uvědomit, jaké etické otázky mohou vyvstat. Netýkají se přitom jen fáze sběru dat, ale celého následného procesu až po vznik výzkumné zprávy (Creswell, 2007, s. 56). Ačkoliv se tedy snažíme čtenáři přiblížit realitu zkoumaného prostředí, popis by neměl vést k jednoznačné 
identifikaci škol, kde se našli učitelé ochotní k zaznamenávání své výuky. V tomto případě nám může pomoci volba škol z větších krajských měst, přičemž ani skrze popis kontextu pozorovaných tříd nemůže určit, o kterou školu se přesně jedná.

Největší část pozorování proběhla v jedné ze zlínských základních škol. Výhodou účasti učitelů z této školy na výzkumném šetření byla jejich pravidelná účast v nejrůznějších projektech (i výzkumného charakteru), takže škola má zajištěný paušální souhlas rodičů zahrnující také možnost zaznamenávání výuky na videokameru za př́tomnosti další osoby, která není zaměstnancem školy. Nebylo tedy třeba absolvovat náročné získávání poučeného souhlasu od jednotlivých rodičů. Tento krok byl naopak nutný u posledního případu, kdy jsem po dohodě s ředitelem školy připravila text souhlasu pro rodiče žákủ ve třídách (uvádím text poučeného souhlasu v př́loze), kde jsme si domluvili natáčení výuky. S natáčením souhlasili všichni rodiče žáků, v jedné třídě se ale stalo, že si několik žáků zapomnělo přinést včas zpět do školy podepsaný dokument. Ředitel školy a zapojený učitel v jedné osobě pak rozhodl o změně zasedacího pořádku ve tř́dě tak, aby nemohli být snímáni na kameru, a jakákoliv interakce s nimi není součástí textu.

Zapojení učitelé většinou neměli zájem získat zpětnou vazbu v podobě tohoto textu, spokojili se s rozhovory v průběhu dní, kdy v jejich tř́dách probíhalo natáčení. Pouze poslední z učitelů, Martin, projevil přání text si přečíst, do procesu tvorby se v podobě členského ověřování zapojit nechtěl. Všichni učitelé byli seznámeni s možností kdykoliv z výzkumu vystoupit, pokud by až v průběhu pozorování získali pocit, že pro ně jejich původní rozhodnutí není přijatelné. Pro respektování etického principu důvěrnosti byla všechna jména učitelů změněna a zavázala jsem se také k tomu, že záznamy výuky budou zveřejněny vždy jen takto anonymně a pouze ve formě transkripce do textu. 


\section{6/ \\ PO STOPÁCH ŽÁNRŮ V EXTENZIVNÍ ŘEČI UČITELE}

V následujících kapitolách se vydáme po stopách extenzivních promluv učitele tak, jak jsem je zachytila a následně interpretovala z datového materiálu. Jednotlivé kapitoly mají podobu důležitých zastavení na této cestě, která vznikla prolnutím zamýšleného směru výzkumníka v podobě výzkumných otázek, překážkami, odbočkami a novými směry během celého procesu výzkumného šetření a v neposlední řadě tím, co jsem na cestě viděla - v terénu, v datech a od učitelů, kteří se stali mými průvodci.

Předtím, než se vydáme na cestu k odpovědím na výzkumné otázky, je však potřeba vyjasnit, jakou promluvu učitele považuji z hlediska práce s daty za extenzivní.

\section{1}

\section{Vymezení extenzivní promluvy v řeči učitele}

Zaměřuji se na řeč učitele, která probíhá v interakci s žákem či žáky prostřednictvím výukové komunikace. Nebudu se ale zabývat řečí učitele v celé její šíři, zajímají mě vybrané promluvy učitele. Promluvu chápu ve shodě se Skaličkou (in Hoffmannová, 2012) jako „část řeči, kterou se na někoho obracíme (k jedné nebo více osobám) nebo odpovídáme na nějaký podnět", přičemž může nabývat různých rozměrů od jedné věty po proslov, ale pro tuto práci je podstatný především ten druhý případ. Hranice promluvy jsou spojeny se změnou mluvčího (Bachtin, in Hoffmannová, 2012). V rámci komunikace mezi učitelem a žákem/ žáky ve třídě tak zaměřuji pozornost na promluvy jakožto segmenty učitelovy řeči, které jsou uchopitelné jako ohraničená část řeči, zároveň však vnímám zakotvenost těchto promluv v celém kontextu promluv předcházejících i následných. 
Promluvy participantů výukové komunikace se vyznačují mnoha charakteristikami, jež mohou být zkoumány. Jejich rozsah je ovlivněn především samotnou komunikační situací a potřebami komunikujících, tedy učitele a žáků ve třídě. Roli může hrát pocit učitele, že je zodpovědný za určitou výukovou fázi, jež je podle Janíka a Mikové (2006) kupříkladu zprostředkování nového učiva, kdy hlavní slovo má učitel a verbální př́ležitosti pro žáky jsou spíše opomíjeny. Žákovské promluvy ve výukové komunikaci jsou pak celkově kratší než učitelovy (Šed’ová et al., 2012, s. 48).

Pohled na zachycená data $v$ transkribované podobě ukázal výrazněji než při prvotním pozorování dané vyučovací hodiny v terénu, že některé promluvy učitele se od ostatních odlišují výrazným rozsahem. Pro další práci s daty pak bylo nutné jednoznačně si stanovit, které ze zachycených promluv učitele z vyučovacích hodin na 2. stupni základní školy budu považovat za extenzivní. Při zaměření pozornosti na tyto promluvy se vynořil koncept extenzivních promluv učitele ve výukové komunikaci, pro který jsem následně hledala i oporu v dosavadní literatuře. Extenzivní promluva je segment řeči, který se vyznačuje délkou nad rámec běžného rozsahu u daného mluvčího, v tomto případě tedy učitele, a informační bohatostí, která se rovněž vymyká očekávání př́íjemce v situačním kontextu. Zároveň se jedná o promluvy, které učitel pronáší, aby tím plnil určitý cíl, čímž se promluva může řadit ke konkrétnímu žánru. Pro analýzu získaných dat jsem se tedy rozhodla opřít se o následující kritéria pojetí promluvy učitele jako extenzivní. Kritéria jsou vymezena z hlediska významnosti, jakou jim přikládám:

- Forma promluvy: extenzivní promluva učitele je souvislým komunikačním projevem, nepřerušená jiným komunikujícím. Ve výjimečných případech mého datového materiálu se vyskytují extenzivní promluvy učitele, na jejichž pozadí probíhá řečový projev jednoho či více žáků, který však není určený učiteli, a ten na ni také ani nereaguje. Pro lepší orientaci čtenáře je tato extenzivní promluva učitele uvedena ve zvláštním sloupci, ve druhém jsou pak zaznamenány podkresové projevy žáků. $V$ textu je ukázka odlišně graficky zpracována. 


\begin{tabular}{|l|l|}
\hline $\begin{array}{l}\text { U: Tak, tady je jedna věc, kterou jste možná někdy viděli, ale } \\
\text { do sešitu si ji určitě psát nebudeme. Slyšeli jste někdy o pojmu } \\
\text { Gaussova křivka? }\end{array}$ & (hlasy žáků v pozadí) \\
Ž: Ne. & \\
U: (maluje na tabuli) Tou Gaussovou křivkou se zobrazuje, \\
nebo pomocí ní se dá... se dá zobrazit spousta věcí a jedna \\
z věcí, která se pomocí ní zobrazuje, nebo ukazuje se na ni, je \\
inteligence. Takže tady...š š š. Tady máme průměr. My všichni \\
se plus mínus nacházíme někde tady, já se ještě podívám, (do prostoru) \\
kde jsou tady ty hranice, průměrná inteligence by se měla \\
pohybovat kolem stovky, takže si predstavte, že tady máme \\
stovku, sto. Když budete dělat inteligenční testy tak sto in- \\
teligenčních bodů, jo? To je nějaký ten inteligenční kvocient. \\
(Jakub, 8. ročník, výchova kobčanství) & To jsem já. \\
\hline
\end{tabular}

- Informační bohatost promluvy: extenzivní promluva obsahuje relativně vysoký počet informačních jednotek. Učitelem komunikovaný obsah v promluvě lze vnímat z hlediska jednotlivých informačních jednotek, tedy oddělitelných segmentů v promluvě, které př́ijemcům přinášejí novou informaci. Extenzivní promluva je sycená větším množstvím informačních jednotek, což vytváří kontrast k ostatním promluvám učitele, které za extenzivní nepovažuji. Jelikož počet jednotek není v tomto př́padě podpořen literaturou, nastavila jsem sama kritérium počtu 6 a více informačních jednotek.

Větší nasycenost promluvy informačními jednotkami zároveň však nemusí korelovat s vyšším počtem slov v promluvě, jak bychom mohli předpokládat. Naopak se v mém datovém materiálu ukazuje, že i méně rozsáhlé extenzivní promluvy mohou být až přesyceny sdělovanými informacemi. Př́́kladem jsou dvě následující ukázky z datového materiálu. $V$ obou promluvách, které řadím k extenzivním, nacházím 9 informačních jednotek, jejich rozsah se však výrazně liší.

U: Vy jste minulou hodinu měli minulou paní učitelku místo, místo mě.(1) Slyšel jsem o prestávce, že jste zvládli tu prezentaci udělat. (2) To znamená měření hmotnosti (3) a hmotnost jako takovou máte probranou (4), takže si ji jenom zopakujeme (5) a já si myslím, že se můžeme věnovat některým vahám (6), to znamená hmotnost (7) a pak se pokusíme probrat nové téma a to je hustota (8). Jde to po sobě, protože jsme měřili předtím objem, pak změříme hmotnost a z toho budem vycházet z hustoty (9). (Martin, 6. ročník, fyzika) 
U: Zima bude mírná a zase bude docela deštivá, jo? (1) Takže, ten oceánský typ znamená, že to podnebí je vlhké a jsou tam mírné zimy a chladnější léta. (2) Děcka, ten oceán totiž neustále v létě ochlazuje, v zimě otepluje. (3) Když půjdeme na, do vnitrozemí, čím budem dál od toho oceánu, tím menší vliv toho oceánu bude. Tak bude samozřejmě míň srážek, čili kontinentální podnebí, nebo vnitrozemské podnebí je suché a jsou tady horká léta a ledové zimy. (4) Protože v létě se ta pevnina dlouho prohřívá a nic ji neochlazuje, takže se víc prohřeje a v zimě se zase víc promrzne, prochladí, jo? Čili jsou tam obrovské rozdíly mezi teplotami. (5) V podstatě my $v$ České republice máme to štěstí, že jsme na rozhraní, (6) já si myslím, že máme takové jako, velmi př́jemné je to počasí. (7) V zimě zimu máme, v létě teplo máme. Nemůžeme říct, že by u nás bylo celý rok teplo, nebo celý rok zima. (8) Tak a srážky se během roku docela mění, pravidelně. (9) (Adéla, 7. ročník, zeměpis)

- Rozsah promluvy: extenzivní promluva učitele má rozsah alespoň 50 slov. Toto kritérium považuji spíše za doplňující a při jeho stanovování jsem vycházela z realizovaných výzkumů, které pracovaly s počtem slov ve výuce u učitele a žáků. Za rozvitou promluvu žáka považují autoři Šed'ová et al. (2014, s. 36) promluvu delší než 10 slov. Janík (2006, s. 98) na základě videostudií výuky uvádí, že učitel použije v hodině v průměru $5 x$ více slov než žák, tedy za rozvitou promluvu učitele bychom mohli brát takovou, která má právě 50 a více slov. Průměrná délka repliky učitele z výzkumu výukové komunikace týmu Šed'ová, Švaříček a Šalamounová (2012) měla 18 slov, naše kritérium by tedy bylo téměř trojnásobkem průměru, což považuji za dostatečně silné.

Uvedená kritéria byla stěžejní pro výběr dat k následné analýze. V transkribovaném materiálu jsem tak nejprve vybrala všechny promluvy učitele a následně sledovala, zda pro ně budou platit všechna tři kritéria - tedy stanovený rozsah, počet informačních jednotek a uzavřená forma promluvy patřící tak jednoznačně učiteli jako mluvčímu. Některé učitelovy promluvy, které se na první pohled zdály rozsáhlejší, tak nesplnily kritérium počtu informačních jednotek přinášejících novou informaci žákovi jako příjemci. Průměrný počet extenzivních promluv na jednu vyučovací hodinu, které splňují daná kritéria, byl 20. Při 24 záznamech vyučovacích hodin se tedy jedná o přibližně 480 analyzovaných promluv učitele.

- Tematičnost promluvy: extenzivní promluva může být jak monotematická, tak i polytematická. Druhý př́pad vzniká plynulým přechodem v řeči učitele bez výraznější pauzy, bez jiného verbálního podnětu v komunikaci mezi učitelem a žákem/ žáky ve výuce. Propojení původně zaměřeného tématu promluvy k učivu s organizačním komentářem ilustruje následující ukázka. Přechod mezi tématy promluvy je zde navíc signalizován i oslovením třídy „děcka“. 
U: Tak, co nás dneska čeká a nemine. Dokončili jsme severní Evropu, ve čtvrtek si napíšeme opakování s mapou, odložili jsme to o trošičku a dnes začneme střední Evropu. Dneska uděláme takovou tu obecnou část a potom už nás čekají jednotlivé státy. // Děcka, já jsem říkala, že nebudeme, když budeme brát severní Evropu, střední Evropu mít referáty z jižní a ze západní Evropy, takže ten kdo ten referát neudělal, má smůlu. Byla to vaše volba, dobře jste věděli zadání, takže volili jste si sami téma referátu, takže bohužel. Eeee, dnes se chystal na referát Kamča a Vašek, jo? Takže to máme ještě severní Evropu. Jo? Dobře. // Takže tím bych dneska začala a potom bychom začali tedy nové učivo. (Adéla, 7. ročník, zeměpis)

- Př́jemce promluvy: extenzivní promluva jako celek je adresována všem žákům ve třídě. Mohou se v ní vyskytovat vložené informace určené jen vybranému žákovi či skupině žáků, ale i tyto případy jsou ojedinělé.

Poznávání extenzivních promluv začneme zodpovězením otázky, jaké žánry lze identifikovat v extenzivních promluvách učitele ve výukové komunikaci. Každou promluvu jsem přiřadila k určitému žánru na základě hlavní funkce a pokusím se rozkrýt, co lze vidět uvnitř těchto žánrů a jak s nimi učitel pracuje. V souladu s pojetím žánrů Mistríka (1975) mě zajímá rovněž využití jazykových prostředků daných žánrů, ovšem odhaluji dále především některé aspekty žánrů z hlediska jejich extenzivity. Zatímco zkoumání žán rové podoby extenzivních promluv jsem postavila ještě na možnosti pojednat o těchto promluvách převážně jako izolovaných segmentech v komunikaci, další cesta toto nahlížení rozšiřuje. V datech nejvíce zastoupený expoziční žánr (např. vysvětlení, komentář...) je zajímavým materiálem také pro zkoumání reaktivnosti extenzivních promluv, tedy jejich provázanost s předchozími a navazujícími promluvami v interakci učitele se žákem/ žáky ve třídě.

\section{2 \\ Žánry extenzivních promluv}

Extenzivita je dimenzí promluv, které lze na základě vybraných charakteristik přiřadit ke konkrétním komunikačním žánrům. Žánr vnímám jako označení pro skupinu promluv, které mají shodné prvky vnitřní i vnější struktury a jsou identifikovatelné př́ijemcem promluvy na základě rozpoznání komunikační funkce žánru. Při práci s datovým materiálem jsem po vymezení toho, které učitelovy promluvy považuji za extenzivní, sledovala následně jejich možnou typologizaci ve vztahu k určitým žánrům. V kapitole 3 věnované možným podobám a pojetí žánrů 
ve výzkumu výukové komunikace jsem představila i několik typologií. Nabízela se tedy otázka, zda je možné některou z nich využít pro tento výzkum. Jejich aplikace na extenzivní promluvy učitele však nebyla možná.

Volba žánru promluvy není náhodným procesem, ale je silně vázána na cíl a funkci promluvy ve vztahu k učitelem sdělovanému obsahu (Mistrík, 1975; Bhatia, 2002). O funkci u promluv uvažujeme vždy proto, že jejich cíle jsou vázány na jednání komunikujícího subjektu (Homoláč \& Mrázková, 2014). Prvotním vodítkem pro mě tak byla snaha postihnout funkci promluvy, která umožnila její zařazení do vznikající typologie žánrů. K tomuto kroku v analýze dat vedla samotná práce se souborem jednotlivých extenzivních promluv, kdy se nabízelo hledání, jak je dále rozčlenit. Již v prvních fázích jejich kódování se ukazovalo, že extenzivní promluvy zkoumaných učitelů obsahují komunikační prvky, které umožňují identifikovat jejich komunikační cíl. Vzhledem k tomu, že mluvčím je ve zkoumaných případech vždy učitel, jeho komunikaci ve třídě stále vede snaha předat a upevnit poznatky, hodnotit sdělení a výkony žáků, organizovat jejich společnou i individuální práci. Komunikační cíl je tedy silně zasazen do kontextu výuky a očekávání jejích participantů.

Rozpoznání funkce žánru v opakujících se situacích ve výukové komunikaci nepředstavovalo překážku v některých případech extenzivních promluv. Pokud obecně vnímáme funkci žánru tak, že umožňuje rozpoznat významy v promluvách prostřednictvím jazykového jednání (Auer, 2014), lze takto konkretizovat funkce u jednotlivých typů žánrů a subžánrů. Ačkoliv učitelé jen výjimečně explicitně verbalizovali cíle ve své řeči, je možné je při analýze promluvy identifikovat. Promluva obsahující výklad nového pojmu k učitelem pojmenovanému tématu učiva bez dalších, doplňujících informací odkazovala k cíli prezentovat nový pojem ve výuce tak, aby s ním učitel mohl později pracovat. Mnohé zkoumané promluvy však neměly jediný cíl. Tedy určitý cíl zřejmě k promluvě učitele na začátku vedl, ovšem během jediné promluvy se dále objevily další. Záměr vyložit nový pojem v učivu se tak mohl krátce rozvinout $v$ hodnocení porozumění souvisejícího pojmu žáky v předchozích hodinách. Častým jevem zachycených žánrů extenzivních promluv je tedy jejich mísení, které se ostatně projevuje i v literárních či slohově komunikačních žánrech. Tento jev v promluvách učitele je zároveň možným vysvětlením pro extenzivitu učitelových promluv.

Pro každou promluvu platilo, že i v případě dvou souběžných cílů promluvy, např́íklad objasnění probíraného jevu i hodnocení jeho zvládnutí žákem, byl jeden z cílů dominantní, což určilo zařazení k danému žánru. Primární funkce promluvy byla patrná ze struktury promluvy. Pokud se do jedné funkce vnořila v promluvě další, učitel se v závěru promluvy vracel k prvotnímu záměru, který zopakoval nebo rozvinul. V průběhu analýzy dat jsem uvažovala i nad tím, zda by jednotlivé 
části promluvy, v níž jsem identifikovala přechody k různým funkcím, neměly být řešeny zvlášt'. Tento přístup by však podle mého názoru posunul pohled na extenzivitu mimo stanovený rámec rozsáhlejších, informačně silně sycených promluv. Extenzivita promluv je určitým jevem $v$ řeči učitele a měla by tak být zkoumána z hlediska celých promluv oddělených až vstupem dalšího mluvčího do komunikace.

Ve zkoumaných extenzivních promluvách jsem nalezla celkem čtyři hlavnížánry: expoziční, instrukční, evaluační a apelativní. Odlišují se hlavními cíli, které mají naplňovat. V expozici si učitel klade za cíl informovat o učivu či jevu a objasnit ho, v instrukci je záměrem předat návod pro činnost a organizaci práce žáků. Cílem evaluačního žánru je hodnotit kvalitu činnosti žáka, nejméně zastoupené apelativní promluvy jsou pronášeny učitelem se záměrem regulovat chování žákủ či nastavit organizaci třídy. K základní typologii čtyř žánrů je dále rozpracována i nižší rovina z pohledu taxonomie. Dílčí cíle patřící jednotlivým promluvám, které tak plní konkrétněji vyjádřenou funkci, jsou základem pro rozlišení subžánrů. Každý ze čtyř základních žánrů má tedy i několik subžánrů.

Identifikované žánry nejsou rovnoměrně rozloženy ve všech hodinách. Především u učitelů vyučujících humanitně orientované předměty (v mém případě tedy český jazyk, literatura, dějepis, výchova k občanství) se vyskytlo jen málo př́padů extenzivních promluv žánru instrukce. Neznamená to, že se v hodinách učitelé nevěnovali předání pokynu či návodu pro zadaný úkol. Většina pokynů pro žáky měla však spíše stručnou formu z hlediska rozsahu. Ve všech analyzovaných vyučovacích hodinách jsem ovšem zachytila množství extenzivních promluv, které řadím k expozičnímu žánru. Následující text je tedy věnován v největší míře právě tomuto žánru, a to jednak ve zkoumání jejich prvků a práce učitele s daným žánrem, a jednak již v širším propojení s kontextem promluv ve struktuře výukové komunikace. 



\section{7/ \\ EXPOZIČNÍ ŽÁNR}

Tento žánr je nejsilněji zastoupen ve všech zkoumaných vyučovacích hodinách, což odpovídá tomu, že učitel v nich bud' vždy přináší nové téma výuky (výkladové promluvy včetně těch, které navíc slouží k zápisu učiva), nebo se věnuje předchozímu. $V$ těchto případech se nejčastěji v komunikaci projeví potřeba učitele něco doplňovat, objasňovat, přidat potvrzující příklad nebo zajímavost. Mnohé příklady expozičních promluv daného žánru jsou dále představeny také v rámci interpretace reaktivnosti promluv jako jednoho ze zkoumaných jevů extenzivních promluv učitele. Expoziční žánr zahrnuje tedy subžánry, které můžeme označit za výklad, vysvětlení, sdělení, komentář, interpretaci probíraného jevu.

Tab. 2 Přehled žánrů extenzivních promluv učitele patřících $k$ expozičnímu žánru

\begin{tabular}{c|c|c|c} 
SUBŽÁNR & $\begin{array}{c}\text { HLAVNí } \\
\text { KOMUNIKAČNí Cíl }\end{array}$ & $\begin{array}{c}\text { DOMINANTNÍ } \\
\text { FUNKCE }\end{array}$ & $\begin{array}{c}\text { PRVKY VNITŘNí } \\
\text { STRUKTURY }\end{array}$ \\
\hline VYSVĚTLENÍ & Objasnit jev učiva & objasňující & $\begin{array}{c}\text { důraz na pojmy, sou- } \\
\text { vislosti, výjimky }\end{array}$ \\
\hline $\begin{array}{c}\text { VYSVĚTLENÍ } \\
\text { S HODNOCENÍM }\end{array}$ & $\begin{array}{c}\text { Objasnit jev učiva na } \\
\text { základě hodnocení } \\
\text { žákovy činnosti }\end{array}$ & objasňující & $\begin{array}{c}\text { důraz na souvislosti } \\
\text { zahrnující hodnotící } \\
\text { výrazy k výkonu žáků }\end{array}$ \\
\hline $\begin{array}{c}\text { VYSVĚTLENÍ } \\
\text { SOUHRNNÉ }\end{array}$ & $\begin{array}{c}\text { Shrnout a doplnit } \\
\text { informace k objasnění } \\
\text { probíraného jevu }\end{array}$ & shrnující & $\begin{array}{c}\text { důraz na uzavřní } \\
\text { tématu, strukturace } \\
\text { promluvy }\end{array}$ \\
\hline VÝKLAD & $\begin{array}{c}\text { Prezentovat nové } \\
\text { učivo }\end{array}$ & prezentační & $\begin{array}{c}\text { důraz na práci s pojmy } \\
\text { k tématu }\end{array}$ \\
\hline
\end{tabular}




\begin{tabular}{c|c|c|c} 
SUBŽÁNR & $\begin{array}{c}\text { HLAVNÍ } \\
\text { KOMUNIKAČNí Cíl }\end{array}$ & $\begin{array}{c}\text { DOMINANTNÍ } \\
\text { FUNKCE }\end{array}$ & $\begin{array}{c}\text { PRVKY VNITŘNí } \\
\text { STRUKTURY }\end{array}$ \\
\hline OPAKOVÁNÍ & $\begin{array}{c}\text { Shrnout a ověřit infor- } \\
\text { mace k probíranému } \\
\text { jevu učiva }\end{array}$ & fixační & $\begin{array}{c}\text { důraz na vazbu } \\
\text { k již sdělenému učivu } \\
\text { zhlediska času nebo } \\
\text { významu }\end{array}$ \\
\hline SDĚLENí & $\begin{array}{c}\text { Seznámit s obsahem } \\
\text { vyučovací jednotky }\end{array}$ & informační & $\begin{array}{c}\text { důraz na časový rámec } \\
\text { a strukturu ve sdělení }\end{array}$ \\
\hline KOMENTÁŘ & $\begin{array}{c}\text { Předat informaci pod- } \\
\text { porující aplikaci jevu } \\
\text { probíraného učiva }\end{array}$ & podpůrná & $\begin{array}{c}\text { důraz na verbalizaci } \\
\text { myšlenkových operací }\end{array}$ \\
\hline
\end{tabular}

Ve snaze vyhnout se pouze pojmenování, která jsou již určitým způsobem zavedena především $v$ didaktice, zvolila jsem pro ně zastřešující označení, které vychází z latinského termínu „expositio“ (v anglické variantě „exposition“).

$\mathrm{V}$ expozičním žánru z analyzovaných dat je dominantní výskyt učitelova vysvětlování. Dalo by se přitom předpokládat, že vysvětlení přichází až poté, kdy vzniká potřeba objasnit jev, kterému žáci nerozumějí. V některých případech ale vysvětlení nacházím tam, kde od učitele zazněla i otázka: Proč...? Práce učitele s odpověd'mi žákủ je popsána v jedné z následujících kapitol, jež se právě věnuje těmto př́ípadům. Ukážeme si však také, že vysvětlení může do komunikace učitel vložit, aniž by potřeba objasnění zazněla explicitně od žákủ ve třídě.

U: Takhle v Austrálii vykopávají mravence, kteří mají jeskyňky asi metr pod zemí a oni tam v komůrkách mají pověšené jiné mravence, kteří místo zadečku, nebo zadeček mají... ${ }^{1}$

Ž1: Jo... zlatý.

U: Ne, tady to říkal někdo. (dívá se směrem k několika žákům)

Ž2: Medonosný.

U: Ano, medonosný. Oni vyberou mravence, řeknou ty, ty ty, ti si naplní zadeček plný těma štávama, oni ho pověsí takhle do spižírny a pak si chodíte pro ten med.

1 V ukázkách $\mathrm{z}$ analyzovaných dat používám grafické rozlišení v textu s cílem zjednodušit čtenáři základní orientaci v datech. Extenzivní promluvy učitele jsou odlišeny kurzivou, zatímco další segmenty probíhající komunikace ve třídě, které tvoří rámec dané extenzivní promluvy, jsou ve standardní formě písma, ale s menší velikostí. Podtržené části textu poukazují na konkrétní části v promluvách, které odpovídají interpretovanému jevu v komunikaci mezi učitelem a žákem/žáky. 
A Aboridžinci se to naučili, protože tam je velmi málo sladkého, po sladkém člověk touží, víte, že když jdete kolem cukrárny tak všichni byste se nacpali, takže oni, protože to pro ně byla taková cukrárna, tak vždycky vykopali potom mraveniště a právě vybrali př́mo tady ty tlusté, jak ř́́kám medonosné, a ten zadeček, podobně jako tvůj děda olizuje kyselinu mravenčí, tak tam byl med. No. (Dana, 6. ročník, př́rodopis)

Vysvětlení jevu, na který si učitelka v souvislosti s učivem (a také v tomto př́ípadě s velmi ojedinělým vstupem žáka do komunikace, který ukázce předcházel) vzpomněla, přichází po skryté otázce „Proč?“. Pouze učitelka sama tak vyvozuje, že nad touto otázkou přemýšlejí v duchu žáci, kteří její výklad sledují, a reaguje tak na domnělou intrakomunikaci.

Vysvětlení ve verbální formě jsou důležitou součástí promluv učitele ve vyučování (Leinhardt, 2001), ovšem v reálné výuce se učitel nemusí dozvědět, zda u posluchačů dochází skutečně k porozumění. Žáci se mohou obávat projevit neporozumění, přichází totiž negativní reakce učitele, dokonce až „ztráta tváře“ (Wittwer \& Renkl, 2008, s. 51). Zkušenosti žáků s reakcemi učitele potom mohou vyústit ve vyjádření očekávaného špatného výsledku, a to paradoxně v situaci, kdy se učitel naopak snaží vést žáka k obhajobě jeho teze, aby přede všemi verbalizoval myšlenkový postup.

U: Vod toho jsou tady ty prevody, vod toho to mám, ve chvíli, kdy mi to nesouhlasí, mám tam hrušky a jablka, jak se ř́ká, tak v té chvíli bych musel převádèt, bud' bych kilogramy převedl na gramy, anebo naopak centimetry na metry jo, ale protože je to vzorovej začátečnickej prríklad, tak to necháme tady v těch jednoduchých rozměrech, které jsme zároveň naměřili, jo, co ted'ka a s tím dál. Co myslíte, Petře. No ted'ka většinou musím stanovit, jak se dostanu $k$ tomu výsledku nebo jakým způsobem zpracuju ten př́klad, jo... stanovím nějakou, nějaký postup, kterým se dostanu k tomu správnému výsledku, tady v téhle chvíli je to strašně jednoduchý, protože jsme to ted'ka dělali, jak se k tomu dostanu, Michale?

Ž: Vynásobím osmdesát tři gramů krát třicet.

U: Proč bych to dělal?

Ž: protože je to a krát a krát a.

U: a krát a krát a. A co tím získám?

Ž: Tak nic.

U: Tak to mášs pravdu, že to budu dělat, ale co tím získám?

Ž: Hustotu? 
U: Nejdř́v objem a potom teprve hustotu, takže já si nejdř́v teda řeknu, nepudu, takjak říká Michal náhodně, ale řeknu si, hustota se vypočítá jako hmotnost dělená objemem. (Martin, 6. ročník, fyzika)

Uvedená extenzivní promluva učitele Martina je příkladem zintenzivnění vysvětlování k procvičovanému jevu, zahrnuje ale sdělení signalizující žákům, že by jim problematika měla být již zcela jasná. Učitel se poté snaží přimět žáka ke zdůvodnění jeho odpovědí. Protože však v hodinách učitele Martina nacházíme doklady takového dialogu jen výjimečně, není divu, že žák reaguje tak, že se raději stáhne v přesvědčení, že odpověd' byla vlastně špatná. Proč by se totiž podle něj učitel ptal opakovaně na něco, co je správně? Opakované komunikační vzorce, které žáci vnímají u svého učitele, hrají velkou roli. Když se učitel výjimečně zaměří na identifikaci zdroje žákovské odpovědi, spíše je tím znejistí. Přispívají k tomu ovšem i obraty typu „A co tím získám?“, jaké používáme spíše v otázkách v mimoškolním prostředí, žáci je tedy neočekávají. Učitel svůj pokus uzavírá rychlým shrnutím postupu řešení daných př́ikladů, které ale jako sled nedokončených informací a jednotlivých pojmů působí zmatečně. Zajímavá je parafráze odpovědí žáka Michala, v níž se objevuje sdělení, jaké žák vůbec nepoužil.

\section{1}

\section{Učitelova práce s pojmy v expozičních promluvách}

Očekávaným obsahem výukové komunikace by mělo být sdělování edukačních cílů, kterých mají žáci dosáhnout. Cíle ovšem nejsou v záznamech zkoumaných hodin identifikovatelné vůbec nebo jen implicitně na základě analýzy celé hodiny, kdy se z jednotlivých činností volených učitelem dá odvodit, co by jeho cílem mohlo být. Co však identifikovat mohu a učitelé se na to soustředí, jsou jednotlivá témata obsahu výuky, vyjádřená obvykle pojmem nebo skupinou pojmů. Extenzivní promluvy jsou tak rozšířenou verbalizací jednotlivých témat výuky, v jejímž centru se nacházejí stěžejní pojmy, a sdělení učitele slouží zároveň jako signál pro žáky, že je třeba věnovat mu pozornost. $\mathrm{V}$ promluvách nacházím klíče pro identifikaci zastoupené typicky výrazy „tak, takže, začínáme, půjdem k..., máme...a budeme pokračovat...".

U:„Takže to máme takový dodatek k té minulé hodině a ted' budem pokračovat v těch potřebách a tak dále. Potřeby, motivy, zájmy. Takže začneme potřebami. ..." (...).

Běžné je pojetí zahájení vyučovací hodiny učitelem prostřednictvím př́mého sdělení, jaké téma bude předmětem aktuální hodiny, případně s odkazováním 
na minulou a navazující výuku. Oporu v orientaci žáků v předkládaném učivu a především souvislostech mezi vysvětlovanými pojmy pak může učitel nabídnout v úvodním sdělení zahrnující nejen to, co přinese aktuální vyučovací hodina, ale především v propojení nového tématu (reprezentovaného v ukázce pojmem „hustota“) s předcházejícími.

U: Vy jste minulou hodinu měli minulou paní učitelku místo, místo mě. Slyšel jsem o přestávce, že jste zvládli tu prezentaci udělat. To znamená měření hmotnosti a hmotnost jako takovou máte probranou, takže si ji jenom zopakujeme a já si myslím, že se můžeme věnovat některým vahám, to znamená hmotnost, a pak se pokusíme probrat nové téma a to je hustota. Jde to po sobě, protože jsme měřili předtím objem, pak změříme hmotnost a z toho budem vycházet z hustoty. (Martin, 6. ročník, fyzika)

Analyzované vyučovací hodiny všech učitelů jsou v celém svém průběhu strukturovány do dílčích úseků ohraničených právě promluvami učitele, který jak verbálně, tak případně s podporou zápisu na tabuli, provází žáky na cestě mezi jednotlivými pojmy. Pokud má učitel tendenci zvládnout v rámci jedné vyučovací jednotky větší část učiva reprezentovaného pojmy, skládá se hodina nakonec ze sledu extenzivních promluv expozičního žánru. Sledovaným jevem v mém datovém materiálu je také přibývání extenzivních promluv s blížícím se koncem vyučovací hodiny. Takto v hodině občanské výchovy 9. ročníku, kde celkově převládl výklad učitele k několika pojmům z nového učiva, reagují žáci s narůstajícím neklidem, a následně i v promluvách učitele $v$ druhé polovině vyučovací hodiny se atmosféra odráží na jeho poznámkách jako „...musíme to dodělat.“, „...jednoduše napište si, že je to náš kladný vztah $k$ něčemu, at' to tady zbytečně nedramatizujeme.".

\section{2}

\section{Strategie učitele v expozičním žánru}

Promluvy každého učitele jsou protkány jazykovými prvky, které zrcadlí jeho osobitý projev, identifikovatelný i z písemných transkriptů bez neverbální složky, která vnímání daného projevu ještě zesílí. I v jednotlivých subžánrech extenzivních promluv nacházím společné jazykové prostředky, které odráží nejen učitelovy vyjadřovací dovednosti, ale i jeho záměr vázaný na funkci promluvy. 


\section{Přepínání registru promluvy}

V průběhu jedné promluvy učitele můžeme vidět přechod mezi uživáním jazykových prostředků typických pro běžné vyjadřování daného učitele a prostředků, které odkazují na formální registr promluvy. Učitel se vrací po neplánovaném vnoření vysvětlení k probíranému jevu k té části výkladu, která už byla zřejmě záměrná. Soudím tak právě podle zachyceného předělu v jedné promluvě, jak po jazykové stránce, tak i v paralingvistické oblasti, kdy se mění tempo a důraz. Přepínání může být i projevem automatizace výkladu, který učitel v každém roce opakuje. Vysvětlení učitele jsou často ve formě prefabrikovaných informací pro pasivní příjem žáků, jen jako doplňující strategie k jiným, v kontrastu s „lešením“ (Wittwer \& Renkl, 2008), které v průběhu měnící se komunikace ve třídě nemůže být připraveným prefabrikátem. Vyjadřování učitele po přepnutí na druhou část je hutnější, vrací se k základním pojmům výuky, pro žáky představuje signál, že je potřeba výklad sledovat, zatímco při předcházejícím objasňování se ve třídě zvyšuje šum.

U: Tady budou spíš Slováci, což souvisí s tím, že jako Zlínský kraj sousedí se Slovenskem a oni tam sousedí s Německem a děcka, tady to pohraničí bylo kolonizováno těmi Němci, tam byla dř́v spíš většina těch Němců, jo, mnohem víc, dneska už ne teda, jo asi to bude souviset i s odsunem Němců, ale prostě ta menšina Německa je tam pořád výrazná, jo, a tam taky když pojede tím směrem, tak už třeba jak se bližíte k hranicím, tak uvidíte třeba německé názvy, to tady nevidíte, proč, jo? Takže tady, tady vlastně ten kraj je takový jakoby, jsou tam důsledky takového poněmčení. Tak..., hustota zalidnění je nerovnoměrná a to souvisí samozřejměs tím povrchem a souvisí to s tím, že to byla, je pohraniční oblast a do toho pohraničí se lidé moc nehrnou. My jsme ale minule probírali kraj, kde teda byla taková výjimka, a na to že to je pohraniční kraj, je tam vysoká hustota zalidnění, nebo vůbec vysoké, velký počet obyvatel, ale souviselo to s tím, že to je významná průmyslová oblast. Který kraj jsme minule probírali? (Adéla, zeměpis, 8. ročník)

Tato objasňující promluva učitele se v probíhající komunikaci objevila proto, že žáci nedokázali sami přijít na požadovanou odpověd' týkající se odlišnosti v obyvatelstvu v pohraničním regionu. Vysvětlovací jazyk učitelky je proto z počátku spontánnější a odráží její přirozený projev s typickými prostředky (děcka, potvrzovací jo?). Zároveň se v promluvě takto odráží nejistota učitele, který nepočítal předem s tím, že bude právě tento jev vysvětlovat. Sám tedy tápe, promluva obsahuje množství informací, jež patří všechny k tématu obyvatel v pohraničí, ale jsou naznačené, nedokončované, učitel vlastně neví, jak přesně žáky nasměrovat. 
Po části spontánního projevu tak přichází předěl a učitelem běžně prezentované učivo, kde se již učitel cítí jistěji.

Jazyk některých expozičních promluv je protkaný uvolněnou mluvou učitele. Uvolnění jazykového vyjadřování má různé podoby. Od dialektu a nespisovných výrazů (ty se netýkaly učitelů českého jazyka) až po silnou expresivitu vyjadřování jako stylové varianty mluvy učitele. Použití odlišného jazyka způsobuje i proměnu naladění žáků. Učitel by mohl takové situace využívat pro přirozenější kontext diskuze se žáky. Místo toho vidíme v datech u většiny učitelů jen „přepnutí“ registru řeči zpět na formální jazyk, očekávaný při výkladu či vysvětlení.

\subsection{2}

\section{Interakční prvky promluvy}

Během daného časového úseku extenzivní promluvy je verbální projev pouze na straně učitele (případně můžeme zaznamenat komentáře žáků mezi sebou, které však učitel nemá slyšet), ale nelze opomenout interakci v podobě neverbálních reakcí žáků. Pokud je něco z promluvy učitele zaujme, pobaví, překvapí, může učitel zachytit nejrůznější odezvu například v mimice žáků. Učitel si samozřejmě uvědomuje, že ve třídě není sám. V jeho promluvách tak dochází také k zavedení interakčních prvků. Ukazují na snahu učitele vložit do extenzivní promluvy verbální kontakt s posluchači, vytvořit zdání kooperativní interakce, naznačit, že stále žáky vnímá a také oni s ním mají stále počítat. Sdělení učitele tak plní i fatickou funkci, kterou identifikoval Jacobson (in Hoffmannová, 1996) a která je zaměřená právě na kontakt s účastníky komunikace. První z příkladů zároveň ukazuje na provázanost se snahou upoutat pozornost žáků. Učitel si přeje poukázat na to, že své žáky zná a rozumí jim, chce se k nim přiblížit, „,namotat“ je na výklad k tématu, které by pro ně mělo být známé.

U: Takže noviny máme další médium a potom je to jedno, které vám strašně moc něco říká, a to je internet. Eee..., loni jsme si to dělili na dvě základní skupiny a internet tím, jak je to tak nové médium, tak v podstatě nedá zařadit do jedné z těch dvou skupin, protože je něco v podstatě mezi... tištěná a mluvená média a zatřetí internet. Proč internet nezařadím do toho tištěného nebo mluveného? (Adam, český jazyk, 8. ročník)

Typické je časté přepínání adresáta (já - ty - my - vy). Některé obsahy promluvy se (spíše zdánlivě) týkají společné práce, společného cíle, vytvoření dojmu kooperace. Objevuje se také verbalizace myšlenek žáka, které učitel napodobuje. Učitel 
však přepíná na „vy...", jakmile chce zdůraznit, že jeho práce v určitém okamžiku končí a dál už se musí snažit žáci sami.

U: Tak, tyto vzorce musíte umět, jo? A vlastně ty budem dosazovat vždycky za tu podstavu, my nic jiného probírat nebudeme. Tak, vy budete mít počítat povrch nějakého hranolu, my si uděláme náčrtek a já doporučuju si vždycky potom si ho rozpitvat. To znamená načrtnout si zvlášt' podstavu, nevidím co znám, co neznám, jestli můžu počítat ten obsah a načrtnout si plášt' to znamená tři nebo čtyři obdélníky, říkali jsme si, že je pro nás mnohem jednodušší, bude vypočítat celý ten obdélník, celý ten plášt', jo, to je půlka. (Adéla, matematika, 7. ročník)

Role učitele je zde náhle zdůrazněna vyjádřením „já doporučuju“, které budou žáci nejspíše chápat jinak jako doporučení, ale spíše jako upozornění na nutný krok, který jim pomůže u spět při ověřování znalostí testem nebo zkoušením. Zároveň je tato informace v množství jiných informačních jednotek promluvy zachytitelným signálem, který napomáhá porozumění sdělení žáky.

Zajímavým dokladem dominance učitele v řečovém projevu je jeho snaha položit žákům otázku, kterou ale v tu chvíli nedokáže jednoznačně formulovat, nabaluje jednu větu na druhou a z původně zamýšlené otázky vzniká extenzivní promluva s formální podobou otázky. Učitel pokládá vedle sebe další a další informace. Bud' je vnímá jako nutné východisko pro správnou odpověd' žáků, nebo jen právě připojuje doplnění na základě okamžité asociace. V následující ukázce je otázka spojena s rozborem básně v hodině literatury 9. ročníku, kdy učitelka prokládá otázky i úryvky z dané básně, aby zdůraznila, k čemu je dotaz směřován, snaží se podpořit svou představu o interpretaci básně. Její přednes ale nemá žádoucí efekt, žákyně až po výzvě odpovídá jedním slovem pouze na poslední otázku.

U: Že si uvědomil, proč umírali a eště, věděli oni, proč vlastně umírají? Když to omyl taktický..., nee oni se to vlastně, proč mrtví zemřeli? Že, že ten člověk na té frontě poslouchá rozkazy, poslouchá rozkazy, plní je a vlastně spousty lidí umírají, ale když se stane nějaká chyba, tak se vlastně ani nedozví, jo? Proč mrtví zemřeli? Pražilo slunce, pálil den, šli dívky vesnické, my šeptali si tiše jen o chybě taktické, hurá o chybě taktické. Pražilo slunce, pálil den i rány pálily, my šeptali si tiše jen, páni se zmýlili, hurá, páni se zmýlili. Našeho vojáka rozhledu věc př́sně nebere, ví treba troubit k útoku a troubit reteré, hurá, troubit reteré. Co to tady vlastně znamená ty tři sloky? Jak se... cítí ten voják obyčejný? Je to těžké? Může on se nějak vzepř́t třeba, může se on na něco zeptat, my šeptali si tiše jen...

U: ...páni se zmýlili. Eli?

Ž: Nemůže. (Eva, 9. ročník, literatura) 
V jiném př́ípadě dokonce učitel uvádí svou promluvu slovy:

U: Tak a moje jednoduchá otázka. Ǩekněte mi, když Nova vyrobí SuperStar, na kterou se dívá, ted' možná řeknu blbost, ale na kterou se dívá odhadem tak dva miliony lidí, tak...

Ž: Víc.

U: Možná i víc, ted' když to spočítám tak i se Slovenskem rozhodně víc, eee, když Nova vyrobí pořad za dva miliony a ČT 2, aby teda byla co nejvíce jim těch diváků ubrat, tak proč nenasadí něco stejně v uvozovkách kvalitního, tím myslím chytlavého pro ty lidi, ale proč tam v tu dobu dává, třeba ted' zase plácnu třeba křest'anský magazín, na který se dívá asi tak tisíc lidí. Já to schválně zjednodušuju, já to nevím úplně přesně, ale v tom poměru s Česko hledá SuperStar je to rozhodně teda mizivé procento, proč ta dvojka tam nedá něco lepšího, proč nenatočí svojí SuperStar nebo něco takovýho. (Adam, 8. ročník, český jazyk)

Jednoduchá otázka se zde vymyká kontrole. Mezi chybami, které učitelé často dělají při pokládání otázek, je tzv. vícenásobná otázka (Gavora, 2005). Tedy sdělení několika otázek těsně za sebou, kdy žáci vlastně neví, na kterou mají odpovědět, nebo reagují na tu, která je pro ně pohodlná. Pro komunikační projevy tohoto učitele je typické, že i stručnou otázku obvykle ještě doplní dalším upřesněním, zde se v linii otázky objevují odbočky, komentáře vlastní promluvy jako „možná řeknu blbost", "ted' zase plácnu“.

Šest učitelů v mém datovém materiálu volí různé strategie, aby během extenzivních promluv udrželi zdání interakce a upoutali pozornost žáků - posluchačů. Téma vyučovací hodiny, na které se tolik soustředí, nebo předmět samotný poskytují možnosti, jaké učitelé občas využívají. Pokud se chtějí pustit do delšího vysvětlování, jež se opírá o dějovou linku, mohou oslovit žáky tak, že je vtahují přímo do děje. Expoziční subžánry totiž přímou interakci obvykle nezahrnují, alespoň v případě mých dat. Učitelka Eva mi v rozhovorech prozradila, že si uvědomuje, že získat si žáky devátých tříd pro učivo literatury je obtížný úkol. V pozorovaných hodinách si ale dokázala připoutat jejich pozornost vlastním nadšením, výklad či vysvětlení podala přirozeným stylem. Jen potom $\mathrm{v}$ záplavě vlastních slov učitele nezbyl dostatečný prostor po žáky, aby se z posluchačů stali rovnocennými komunikačními partnery.

U: My se vrat'me rychle zpátky k tomu Viktoru Dykovi. Ten napsal zmoudření Dona Quijota, když ten Quijote zmoudř́í, co se najednou stane?

Ž1: Může zemřít. 


\section{U: Prosím? (neslyší dopověd')}

\section{Ž2: Přestane věřit.}

U: Přestane věřit, ted' si vemte, že on ztratí veškeré ideály, ztratí všechno, čemu on kdy věřil, pozná, že ho lidi klamou, že ho mají za hlupáka, že ostatní se k němu chovají úplně jinak, než on čekal, prožre vlastně, co se asi stane? Prosím? Bude naštvaný, bude úplně vlastně z toho zklamaný, protože ten Don Quijote zmoudří, proz... prozře ze svých ideálů a vlastně úplně jako...skončí. Tak Viktor Dyk, Viktor Dyk je tedy spisovatel, dramatik, prozaik, taky ironik a poprvé tedy použil to slovo buřič, ano? Vyburcovat nějak tu společnost, i když za to byl ve vězení, my dneska známe koho? Dyka kterého? (Eva, literatura, 9. ročník)

Uzavření promluvy nám zde ukazuje příklad iniciace učitele, kdy následná replika žáka může opět vzbudit zájem třídy. Shoda jména spisovatele a zpěváka, který je v dané věkové skupině přinejmenším známý, vybízí žáky sice ke stručné odpovědi, ale s možností sdělit svůj názor, porovnat oba umělce, reagovat na nečekané propojení literárního učiva se zájmy žáků, kvůli nimž je učitel ve třídě. Projevil se zde celkově odlišný přístup učitelky Evy, která si podle svých slov „chodí do tříd devátáků odpočinout“, protože většinu výuky má aktuálně na prvním stupni. Také učitel Jakub dokáže využít potenciál vtažení do děje historických událostí, které potřebuje žákům představit. Neobvyklými formulacemi přenáší bitevní útoky přímo do třídy. Ani poutavé objasňování však nemůže fungovat, pokud v hodině nastává naprostá převaha výkladu učitelem, což je právě případ učitele Jakuba.

U: Ted'se budeme zase věnovat Německu, Rusku dáme chvilku pokoj, dokud na něho to Německo zase nezaútočí, což bude přiští hodinu. Takže, západní tažení napište si první větu do sešitu, kterou to všechno začne, překvapivě, v dubnu devatenáct set čtyřicet, $v$ dubnu devatenáct set čtyřicet, dneska se budeme pohybovat celou hodinu v roce devatenáct set čtyřicet. (Jakub, dějepis, 9. ročník)

Učitel se zde stává mluvící učebnicí. Jeho výklad je poutavý, navíc s využitím společného vyjádření „my budeme“. Tuto výhodnou strategii je však potřeba podpořit i strukturací dlouhých promluv a poskytnutím prostoru žákům. Další identifikovanou strategií učitelů, jak upoutat při expozičních promluvách pozornost žáků, je odkazování na to, že učitel vnímá, koho má před sebou, ke komu mluví. Snaží se žákům dát najevo, že jim rozumí, zná jejich preference.

U: Protože internet je jak tištěný, tak mluvený, protože ted' má každá televize svoje video zprávy, Nova tn.cz, pokud se někdo díval na zprávy, tak možná víc než ty zprávy ho zaujala ta slečna, co je povídá ale, eee...oni to myslím zrušili to „nahraj 
zpravodajství", už to myslím nefunguje, ale co, to je jedno...eee, když se k tomu vrátím, tak tištěná média budou co asi...nejspíše? To budou ty noviny, nebo nějaké ty časopisy. Mluvená? Rozhlas teda a... (Adam, český jazyk, 8. ročník)

Vracíme se však stále ke stejnému momentu - učitel vsune své předpoklady do jednolité extenzivní promluvy místo toho, aby se raději v dialozích se žáky na jejich zájmy ptal, a následně z nich vycházel při vysvětlování učiva.

Jednodušší podobu, jak upoutat pozornost žáků, mají různé formy slovních vykřičníků učitele během promluvy. Slouží ke zdůraznění toho, co učitel vnímá jako problematické, potencionální chybu, kterou by žáci mohli udělat.

U: No jedem. Tak. A pod to si napište, že jsou to používanéjednotky v̌̌ivotě jo, když prijdete do stavebnictví a řeknete, že chcete dva tisíce kilogramů písku, takhle na vás budou koukat (ukazuje grimasu) oni vám samozřejmě budou rozumět, ale běžnější je když tam někdo prijide a řekne, já bych potřeboval jednu tunu písku. Jo. Používané jednotky v životě. A pozor, jo s těma nezacházíme jako s těma, s tou standardní základní jednotkou, která včetně předpony neexistuje...kilo, tuna. Jo. To by třeba Poláci špatně rozuměli. Jo, Slunce váží, máš tam tolik nul, kolik tě ani nemůže napadnout. Schválně, Dominiku, kolik váží Slunce kilogramü. (Martin, fyzika, 6. ročník)

Promluva učitele působí celkově uvolněně, odráží se v ní komunikační styl daného učitele, který ve třídě vystupuje "jako na jevišti“ (Wubbels \& Brekelmans, 2005 , s. 7). Tento dojem je pak ale v rozporu právě s tím, že prostřednictvím expozičního žánru má v úmyslu upozornit na jev, který by pro žáky mohl být obtížný. Verbální vykřičník je tak v záplavě odbíhajících humorných informací silným záchytným bodem pro žáky. Promluva celkově přináší množství informací, mezi nimiž sice učitel vytváří propojení, ale jedná se o rychlé, nečekané přesuny. Žáci ještě vstřebávají problém, jenž by je potkal ve stavebnictví při použití nevhodné jednotky, a už se musí zamyslet nad váhou Slunce. Podobně se význam sdělení ztrácí i v prŕípadě, že učitel chce podpořit porozumění učivu několika prŕíklady, které si v tu chvíli vybavuje.

U: Prosím vás, ještě jednou říkám, že když, eee, řeknu, že ve vypravování v tomhletom okamžiku by tam měly být citoslovce, tak že tam vyloženě musí být. Jo, tady se to třeba nehodilo, tady nikdo neprásknul dveřmi, takže tam zase neviděl bych to jako velkou chybu, ale chápu, že jsme si ř́kali, že by tam měly být citoslovce... eee, mně se tam spís nelíbila jedna věc, můžu si to pučit, prosím tě, Honzo, já jsem si to nepsal úplně všechno... a to je stálé opakování jednoho slovíčka, kterého si, 
kterého se těžko zbavujeme, protože v podstatě v tom minulém čase v první osobě se používá skoro pořád. (Adam, český jazyk, 6. ročník)

Pro zesílení, zdůraznění objasnění tématu používá v některých případech učitel apel, provokaci, sdělení, které může u žáků vyvolat reakce a odpovědi, jež konečně nespadají jen k těm požadovaným.

U: (...) ale tak v porovnání, v porovnání s tím, se zprávama na Nově se na to dívá strašně málo lidí, to je jedno, že starší, no tak se na starší vykašlem, když nám ten pořad nevydělává, tak se na něj vykašlem a dáme si tam ještě jednu SuperStar... (Adam, český jazyk, 8. ročník)

V tomto případě tedy žáci do komunikace vstupují a mají zájem vést dialog. Nevýhodou je, pokud se učitel v jiných případech dopouští té chyby, že apel stejně jako jiné důležité výpovědi v promluvě „obalí“ množstvím dalších informací, které ukryjí žákům správný okamžik, kdy se mohou k tématu sami zapojit.

Humor, vtipné komentáře, to vše ve vyučovacích hodinách jako součást expozičního žánru přináší uvolnění atmosféry ve třídě. Humor však vidím také jako odraz učitelovy snahy upoutat pozornost, možná více k vlastní osobě, než proto, aby prezentované téma výuky žáky (konečně) zaujalo, vyvolalo alespoň neverbální reakci v podobě úsměvu nebo zvednuté hlavy od sešitu se zápisem. Odezva žáků se v některých případech daří, většinou však učitel jen vsune humornou poznámku a pokračuje v řeči bez přerušení.

U: Začal jsi psát rovnou třetí sloučeniny, protože asi něco z toho umíš, ale ti z vás, kteří ty kyseliny nepíšou, anebo mně napíšete kyselinu a najednou tam stojí úplně jiná, spadne vám tam někde z Měsíce napíšete si há dvě es ó čtyři a pak mě napíšete, že sůl je en á vymyšlené. Nebo cé há cé ó tři od síranu, prostě jde vidět, že tomu nerozumíte, že to neumíte dát dohromady. Kubo, z které kyseliny je aniont? U této soli. Které? Nahlas. (Dana, chemie, 8. ročník)

Humor byl jedním ze základních prvků, který ve vysvětlování učiva ve výuce fyziky identifikoval D. Geelan (2013, podrobně kap. 3). Jeho funkci vidí především v uvolnění atmosféry ve třídě. Popsal pak humor z vyučovacích hodin fyzikářů jako spíše suchý, případně specifický humor, jaký pochopí pouze lidé z oboru (ovšem jeho výzkum se týkal středoškolských studentů, takže učitelé měli před sebou zcela jiné komunikační partnery). V následující ukázce vložení vtipu do výkladu učitele Martina se také věnujeme tématu z hodiny fyziky, jeho humor však zaniká tím, že žáci 6. třídy dnešní generace už narážku na shodu slova „tuna“ se slovenským výrazem jiného významu neodhalí. 
U: Tisíc a další tři nuly. No, dobře. Jo, bude to takto. Jenom, kdo to tam nepochopí, nemůže pak dobře prevádět ten kilogram a kilogram na gram, jo. Tak proč teda máme nějaké jednotky, které nesouvisí s tím dohodnutým systémem. A nemáme náhodou ještě nějaké další? Tuna, kde se vzala tuna. Zo Slovenska, tuna něco je. (usmívá se, žáci bez reakce) (Martin, fyzika, 6. ročník)

Příklad demonstruje přechod na neformálnost v řeči učitele, kdy učitel vytváří zdání otevřené komunikace, možnosti diskuze. Žáci čekají na signál, který jim napoví, že jejich vstup do komunikace je možný, lze uvažovat nad humorem jako prvkem, jenž by je podpořil. Ovšem stejně jako celé vysvětlení učitele, i humorné narážky musí být přiměřené porozumění žáků. $V$ případě učitele Martina se v datech setkáváme bohužel také s osobně laděnými negativními výroky k jednotlivým žákům, především těm, které si učitel zřejmě identifikoval jako problémové. Nevyváženost vtipných a nevhodných komentářủ, jimiž učitel prokládá vysvětlování, tak vyvolá v žácích spíše zmatek.

\subsection{3}

\section{Učitelovy verbální přešlapy}

Vyučování ve třídě je nabité emocemi a osobní historky učitelů jsou plné emočně silných momentů. Naturalistické studie identifikují učitelovy emoce jako klíčové faktory ovlivňující strategie učitele ve výuce, především ty manažerské. Pokud nejsou učitelovy negativní prožitky a emoce s nimi spojené adekvátně zpracovány, může být následkem v chování učitele rozhořčení nebo cynismus (Emmer, 2001).

U: Tři chlorečnany, jestliže má něco hodně kyslíku, může to se to používat na výbušniny. Můj švagr používal chlorečnan, nasypete k tomu puding, který má hodně uhlíku, dobře hoří, když chcete, aby to házelo jiskřičky, pridáte nějaké kovy, zapálíte a můžete přerazit strom, mủžete vyrazit dva metry vody, může vás to zabít, může vám to utrhat ruce a toto je jedna $\mathrm{z}$ běžných sloučenin, která se používá na výrobu výbušnin. Nebudeme ř́ḱkat, jakým způsobem se to dá dohromady, protože to už nemůžu, ale dusičnany opravdu slouží k tomu, a pokud budete číst, nějaké tajné př́pravky na výrobu výbušnin, vždycky tam je tadleta sloučenina, př́padně chlorečnan, který býval v Travexu. Jak to kluci začali využívat, tady na ty výbušniny, tak Travex stáhli a ted' už je nějaká jiná sloučenina, kterou tam teda nedávají ten chlorečnan, docela běžně dostupné tyto sloučeniny. To máme dusičnany, máme čtvrt. Ještě tam je tam něco? (Dana, chemie, 8. ročník) 
Ironický komentář učitele tak provází kupříkladu doplnění učiva, které se učitel snažil předtím získat v odpovědích od žáků, ovšem bez úspěchu. Možná i proto naznačil žákům, že potřeba vzdělání pro ně zřejmě není aktuální, a učivo reprezentované daným pojmem rozvíjí dále pokynem týkajícím se požadavků na jeho zápis do sešitu žáků.

U: Nevím, jestli u vás to bude úplně platit, ale jednou z takových sociální potřeb může být potreba vzdělání (otáči se zády k žákům, píše na tabuli), to vám dojde až pozdějic. Vzdělání, pak může být potřeba radost, mít radost, čili radosti, štěstí, lásky a tak dále a tak dále. Tak, to máme jeden takový úkol, $k$ těm potřebám, a abychom je měly kompletní, tak si budeme muset ted'ka něco namalovat, nebojte se, nebude to žádný veliký obrázek, bude to jenom tak na rádky taková pyramidka. Tak napište si na další řádek, hlavně zkuste nezkomolit to jméno... (Jakub, výchova k občanství, 8. ročník)

Sami učitelé tyto výroky chápali nejspíše jako humorné, obvykle se pousmáli a pokračovali dále v promluvě, ovšem žáci na ně bud' nereagovali, nebo se v některých lavicích začali bavit mezi sebou.

Gradací nevhodného chování učitele vůči žákủm je verbální represe, která je v některých případech součástí extenzivní promluvy, která se primárně vztahuje k prezentovanému tématu, ale učitel zároveň spontánně reaguje na vnímaný problém ve třídě. Nevhodné chování učitele je vymezováno různě, ale v typologiích jsou popsány právě interakční přešlapy učitele, který si zasedne na žáka (Lewis \& Roley, 2009 in Mareš, 2013) a soustav ně ho podhodnocuje. Interakční teorie nevhodného chování učitele Wubbelse a Levyho (2005) charakterizuje tři typy učitelů. Množství a obsah zaznamenaných dat mi neumožňují stanovit, zda některý z učitelů patř́ $\mathrm{k}$ daným typům. Přesto nacházím prvky represivního typu, především v ironii a potlačování iniciativ žáků, zastrašování zkoušením, navozením obav z toho, jak dopadne zkoušení, protože učitel předem poukazuje na možné neúspěchy.

U: (...) Obvod podstavy, véje výška hranolu. Toto mě prosím vás zítra řeknete, běda jakne Kristýno a žádné takové čožé, jako obsah trojúhelníku, vy si jako ani neumíte poznačit, co je v písemce. Proto jsem vás upozorňovala a ř́kala, ukazovala na té síti, podívej se, tady mám podstavu, jeden rozměr, je tady druhý, je tady třetí, je tady a vše, pak jsme vyplnili společně, celou tady tu délku toho velikého obdélníku. Když ty jednotlivé obdélníky spojím, tak to je jeden veliký. Tudíž zase, obdélník počítám jedna strana, krát ta druhá, a ta jedna strana se rovná obvodu té podstavy, krát ta výška. Čili když budeme počítat povrch libovolného hranolu, musíte ovládat vzorečky, opakuju obsahu trojúhelníku, čtverce, obdélníku, lichoběžníku, 
rovnoběžníku, pět vzorečků. Kdo není schopen se naučit pět vzorečků, tak nemá co dělat v sedmém ročníku. A pak ten plášt', že je to obvod podstavy a výška hranolu, a pak už všechno dokážeme, protože podstavu určíme, to budeme vědět co je a určíme pak i ten plášt'. Zítra už konkrétně na př́kladech, ale běda jak toto zítra nebudete umět. Nezapomeň v zeměpise je písemka z jižní Evropy a referáty, těším se na referáty, jo, tak. (Adéla, matematika, 7. ročník)

Výroky mohou být namířené na konkrétního žáka, kdy přitom může hrozit riziko, že se jedná o někoho, kdo je v třídním kolektivu už i tak outsiderem, kterého potenciálně ohrožuje ostrakismus. U tří zkoumaných učitelů se v hodinách opakovaně objevují narážky na vybraného žáka, jenž nesplňuje učitelovy požadavky na výkon nebo chování.

U: (...) Třída si to s tebou pak vyřídí, kvůli tobě budou počítat další př́klad. A ti co se začnou bavit pred zvoněním, přidávají minutu třídě, tak se rozhodněte, jak chcete. To už je zaokrouhleno, kdo má šedesát tři jsme ř́kali je to dobré, dostačující. Kluci nemusí psát odpověd', vy všichni ju mít musíte. V písemce celý př́klad škrtám, pokud nemám odpověd'. Takže, pro ty co nerozuměli, prečctu si př́lklad, kolik hydroxidu, zapišu x. Sto gramů kyseliny dusičné, napišu sto. Pod to vím, že musím zapsat molární hmotnost, násobeno počtem molů, tady je to jedno, proto jste to nenásobili a pak už je to stupidní trojčlenka, kterou počítáte v matice dnes a denně. (Dana, chemie, 8. ročník)

Zastrašování namířené zdánlivě neurčitě celé třídě je také určeno žákům, kteří zřejmě vnímají, že se jich týká. Spolu s nimi ale působí i na ostatní žáky ve třídě, kteří mohou cítit obavy. Pohrůžka učitele Martina v následujícím příkladu se vztahuje přímo k probíranému učivu - učitel si uvědomuje, že pro některé z jeho žáků je obtížné nebo nezvládnuté natolik, že zkoušení jim přinese trest za vyrušování v podobě neúspěchu.

U: Jeden kilogram. Výborně. Jo. Převádět nebudeme. I když bych mohl. Pokud mě tady bude někdo rušit, tak si ho vyvolám k tabuli na převod a bude. Takže gramy a kilogramy a s něčím dalším. Jo, jo ale víte, co jsme dělali, já jsem tam v zápise myslím neměl, to tam je potřeba dopsat u té hmotnosti, jako takové existují totiž fyzikální, když už jsme u těch jednotek. Jednotky hmotnosti, které nejsou, máme tady tu naši tabulku. Máme, které nejsou, vytvořené pomocí předpon, u obsahu to byl hektar, ar, u hmotnosti to budou... (Martin, fyzika, 6. ročník) 
Mezi všemi informacemi, které učitel sdělil v jediné promluvě žákům, je pohrůžka lehce ukrytá. Žáci ji však bezpochyby vnímají, což se paradoxně projevilo zvýšeným šumem ve třídě, tedy proti samotnému důvodu jejího vyřčení. Většina žáků pak neměla možnost zachytit podstatnou informaci týkající se toho, že k probírané hmotnosti je potřeba si ještě něco doplnit v zápise.

\section{3 \\ Proklamace významu obsahu promluvy}

Extenzivní promluva může být učitelem využívána nejen $\mathrm{k}$ tomu, aby uceleně žákům objasnil obsah sdělovaného učiva, aby využil dostatek času propojit prezentované nové poznatky s předešlými, ale potenciál expozičních žánrů vidím také $v$ tom, že učitel má možnost během promluvy připojit argumenty podporující význam sdělovaného. Extenzivní promluva, se kterou učitel cíleně pracuje, dokáže podporovat přijetí obsahu žáky nad rámec jednodušších kognitivních procesů jako zapamatování si poznatků. Taková nadstavba v překládaných poznatcích má v námi zkoumaných datech několik podob, kdy učitel komunikuje žákům význam překládaného obsahu promluvy expozičního žánru.

\subsection{1}

\section{Upevnění významu promluv}

Za př́nosné lze považovat př́ípady, kdy učitel demonstruje význam sdělení „pro život". Takové vyjádření významu jsem častěji zaznamenala v přírodovědných a technických předmětech, které k tomu nabízejí dostatek př́ležitostí v rámci kurikula základní školy. Žáci se seznamují s mnoha principy fungování jevů, jejichž pochopení by mělo být položeno na silnějších základech, než je úspěšnost školních výsledků. Explicitní vyjádření významu „pro život“ nacházím kupř́íkladu v hodině fyziky. Na základě pozorování interakcí mezi učitelem Martinem a žáky a po rozhovorech mezi natáčením jeho hodin se také zdálo, že podobné přemostění mezi vysvětlovanými fyzikálními jevy a situacemi v běžném životě využívá také proto, aby žáky zaujal či pobavil.

U: Metrák se používá, jo. Takže s tímhle tím se setkáte v běžném životě, je to zjednodušení toho používání těch jednotek. Pořád je to zažité, ve stavebnictví se to třeba používá jo a třeba tu tunu, jako takovou (píše na tabuli) to je právě v té značce, když máte tu značku tak tam máte třeba osm celých sedm t, a to pro toho 
kamioňáka znamená, že podle toho jakou má hmotnost on a jeho náklad, tak podle toho on může do toho mostu vjet nebo na ten most vjet, nebo na ten most nemůže vjet. Kolik myslíte, že má takový obyčejný auto tun. Václave, obyčejný osobní auto.

V opakování u základních jednotek hmotnosti se tak na chvíli přeneseme mimo předmět samotný a za zdi školy. Chvíle, která by žákům dala možnost navázat vlastním komentářem či otázkou, ale přešla, učitel poukázal na to, co vytváří hmotnost auta a pak se jeho promluva uzavírá tipovací otázkou a žáci se následně vrací zase zpět k sešitům a zápisu učiva.

Stejný učitel ve vysvětlení zároveň přímo poukazuje na odlišnost významu pro potřeby školy a případy, které budou přesahovat „školní měření“.

U: V matematice, jo. Jde o to, že vy máte na těch prstíkách nejenom vy, ale i já zbytky svačiny, Kubo, mastnotu, špínu a podobně. Někteří víc, Kubo, někteří mín̆, že. No a tahlencta nečistota by mohla ulpět na tom závažíčku a potom by to mohlo narušit to měření, $v$ tom našem školním měrení to zas tak důležité není jo, protože to vyvažování vám bude docela složité, nebo ne složité, ale bude to docela piplačka na jednu stranu, jo. A na presnosti, která bude dosažená, nebude zas tak veliká, na druhou stranu je dobré se ten princip naučit, my jsme se totiž bavili o nějaké chybě měření a je důležité se naučit to, že každé měření má svou chybua že je důležitéjak to měření provádím, protože i to mě může tu chybu hodně ovlivnit. Aby nebyla moc veliká. Jo, tak jaké máme typy vah? (ukazuje na žáka a sedne si na učitelský stůl)

Zatímco některé učitelovy promluvy podporují vazbu předkládaného obsahu na uplatnění poznatků v životě žáků mimo zdi školy, v jiných dochází naopak k oddělení toho, s čím se žák běžně setkává, ale škola reprezentovaná učitelem to prozatím vysvětlovat nebude. Projevuje se ale, že učitel předává množství poznatků, které jsou pro něj již zřejmé, má vytvořený systém souvisejících znalostí. Během promluvy, která je určitým typem nabalování informací v toku řeči, se dotkne tak i tématu, o kterém vlastně mluvit nechce. Seznamuje přitom žáky s druhy vah a zároveň explicitně odsouvá pojmenované běžně používané váhy mimo zájem žáků. Kdo z žáků by pak položil otázku k tomuto tématu, aby vstoupil do řeči učitele?

U: Třináct. Já své šestileté dceři vysvětluju, že ve škole to bude muset vydržet a on se snaží ve třinácti, člověče (ukazuje rukama), tak stane se. Takže pak jsou těch tř́ druhů, co jsem vám do toho sešitu nechal napsat, tak jsem potom napsal, to poslední, to je asi nejširší, v dnešní době nejvíce využívané jsou váhy digitální, jo. Princip digitálních vah nás zatím v šesté třídě nezajímá, jo, tak. Takže to máme $k$ vážení, chcete se na něco zeptat u těch vah jako takových i k měření hmotnosti? 
Čím, to víte? Tak se zeptáme. Jonáši, prosím tě, pojd' k tabuli. Nakresli mně, napiš mně, jaká je značka pro hmotnost a jaká je základní jednotka. Všechno víte. (Martin, fyzika 6. ročník)

Učitelé si mnohdy sami uvědomují a následně verbalizují význam sdělovaného obsahu jak pro požadavky školního hodnocení, tak i pro uplatnění poznatků v životě. Zároveň je vypíchnutí názvu v následující ukázce podpořeno určitým zlehčením, slovní hrou mezi učitelem a žáky, kteří vědí, že si slova o „náhodném objevení v písemce" mají přeložit naopak tak, že po nich tuto znalost učitel bude požadovat.

U: Takže Francie spoléhala, spoléhala na Maginotovu linii. Maginot, to byl ministr války ještě v prèedcházející etapě, předcházející době, v nějakých dvacátých, třicátých letech, francouzský ministr války, nemusíte vědět. Ale Maginotova linie si pamatujte, notoricky známé, Maginotovou linií, linií, Maginotova linie. Dejte si to klidně do závorky, soustava opevnění, nebo prostě opevnění, na hranicích s Německem, čili klasické bunkry, samozřejmě mnohem větší, než byly ty u nás, tady je to ještě doplněné o krásné domečky, nevím, jestli bych tam chtěl bydlet tak hned vedle toho, určitě to znáte, vsadím, že někteří z vás už to viděli na našich hranicích, je to takové podobné stavby. Takže Maginotova linie při hranici s Německem, jo? Kdyby se to náhodou objevilo v písemce, nebo v životě jste to někdy někde viděli, tak nebud'te překvapeni, co to je ta Maginotova linie. (Jakub, dějepis, 9. ročník)

V analyzovaných promluvách expozičního žánru jsou však žáci konfrontováni častěji s potřebou vnímat význam sdělení především „pro školní úspěšnost“. Svět školní třídy se pak jeví jako uzavřený prostor, v němž se žáci dozvídají poznatky, které je třeba následně komunikovat ústně či písemně opět jen v daném prostředí. O významu učiva pro získání potřebných kompetencí se nedozvídají, také se však ani neptají.

U: Tak zaprvé tady to je sloh, budeme to psát do slohu, to se omlouvám, že jsem vám neřekl, to nebude do domácího sešitu, bude to do slohu a za druhé, pokud mi to jenom přepíšeš tak to je tak za čtyři, protože to není to nejdůležitější. Nejdůležitější je napsat vypravování tady podle té osnovy. Rozumíte tomu? Tak to jsem rád. Tak, zavřete sešity, teda učebnice, tak a trošku si to zrekapitulujem. Vypravování, hlavně pořád dokolečka to děláme z jednoho, z jednoho prostého důvodu, že přiští týden naposled budeme trochu procvičovat a za čtrnáct dní nás čeká co?

Ž: Konec školy. 
U: Konec školy určitě ne, za čtrnáct dní nás čeká kontrolní slohová práce. (Adam, český jazyk, 6. ročník)

Předchozí př́klady se dotýkaly učitelova pojmenování toho, proč je vlastně jeho výklad, vysvětlení či sdělení důležité. Nacházím pak i dostatek př́ípadů, kdy učitel vloží do extenzivní promluvy formulace upevňující význam sdělovaného. Může tak v rámci vysvětlování jevu zodpovědět na skrytou (někdy však i žáky vyslovovanou) otázku, proč vlastně mají ve škole absolvovat daný předmět. Stejně jako v jiných př́kladech i zde platí, že učitelé přírodovědných a technických předmětů mají oporu v množství informací propojujících svět ve škole a mimo ni, které mohou motivaci žáků zvyšovat. Obzvlášt' pokud po extenzivní promluvě přichází i prostor pro dotazy a komentáře žáků.

U: Jo, protože víš, že tato látka, pokud je více koncentrovaná a je to chemikálie, tak byste se měli nějakým způsobem chránit, nelétat po té zahradè, fíkat to všude, nedivat se, odkud vane vítr a dýchat to prímo, když stojite proti větru, proto tu chemii máte, abyste si o určitých látkách uvědomili, že to, je to chemikálie, může to uškodit, takže dávat si pozor. Další látka. (Dana, chemie, 8. ročník)

Učitelka Dana využívá takto motiv prevence nevhodného používání běžně dostupných chemikálií v domácnosti, ale jako celkově dominantně se projevující učitelka téma ukončuje a žáci výzvu uposlechnou.

U: Dívejte, ne nadarmo jsme předtím, než jsme dělali hustotu, probírali hmotnost a objem. Jo, když budu mít špalek nebo nějakou kostičku ze dřeva a tu stejně velikou kostičku z nějakého kovu. Budou mít stejný objem, já dám váhu, nebo dám nějakou houpačku rovnoramennou, co myslíte, která z těch kostiček bude ležet na zemi. Na té, na té. Na tom spodku (ukazuje rukou). (Martin, fyzika, 6. ročník)

\subsection{2}

\section{Popření významu promluvy}

V datových záznamech nacházím rovněž případy promluv, které nejen že popírají samotný význam toho, co se učitel snaží vysvětlit, ale dotýká se i samotné motivace žáků pochopit dané principy. Učitel tak stírá vlastní důležitost. V ilustračním př́kladu z hodiny fyziky odkazuje učitel na část učiva, kterou je potřeba mechanicky ovládnout. Jeho netrpělivost je dána tím, že učivo opakuje a snaží se zároveň 
posunout $\mathrm{k}$ dalšímu tématu. Jak překvapivé může potom pro žáky být zjištění, že i vzorce pro výpočty mají své zákonitosti a různé možnosti využití.

U: Hm...dobře, tak protože né vždycky to všem je zřejmé, tak jenom se podivej, tady, to zas nefunguje, já tam potřebuju jinou barvu, do koše, do plastů, nebo někam. Je to jasný? V tom vzorečku, a krát, a krát, a, jenom přepíšete tu hodnotu toho áčka, necháte ty znamínka, sčítání a odčítání, násobení, dělení. Lo, a nemusíte nic vymýšlet, nemusís nad ničím preméšlet, prostě to jen mechanicky doplníš, jo, Václave. Tak. Ted' se bojím toho. Ale zkus to, vynásob ty čtyři celé devět, krát čtyřri celé devět a potom to celéještě čtyři celé devět. No... a znáte násobení desetinných čísel, že jo, někdy z páté třídy, ze čtvrté? Kdy jste se to učili, Magdi. (Martin, fyzika, 6. ročník)

Osobně laděný komentár̆ týkající se předstírané obavy učitele, jak si s návodem pro řešení žák poradí, také nepřispěje k motivaci žáka pro zvládnutí učiva. Ještě silnější demotivační prohlášení učitele, které ale mohlo být vedeno snahou naopak žáky přesvědčit o jednoduchosti požadavků, aby neměli problém uspět, objevuji i v dalších hodinách.

U: Stačí. Všecky jsme v atlase našli jo, všecky bysme uměli děcka, všimněte si, já když vám dávám písemky s tím atlasem, vy vlastně nemusíte nic umět, jenom najít $v$ mapě město a vidět tam tu značku v tom, vy jste všechny tyto města právě uvedli. (Adéla, zeměpis, 8. ročník)

Podobně může učitel vyjadřovat až vlastní nechut' k samotnému učivu a požadavkům kurikula. „Tak...bohužel si musíme nasázet tady ty...definice.“, „...takže jenom jednoduše, že je to náš kladný vztah k něčemu, at' to tady zbytečně nedramatizujeme." Taková prohlášení pak mohou přinést učiteli i „kladné body“ z hlediska vnímání jeho osoby žáky. Učitel jim sděluje, že kdyby to bylo na něm, dané učivo by vůbec neprobírali, nebo se mu věnovali jinak. Do komunikace se náhle dostává „někdo“ nepojmenovaný, kdo rozhoduje o obsahu výuky, a komentář učitele je tak určitým alibismem namísto snahy zpracovat vysvětlované učivo interaktivně a tak, aby nebylo potřeba se vyjadřovat $\mathrm{k}$ jeho důležitosti, protože žáci ji budou vnímat sami.

Expoziční žánr identifikovaný v datovém materiálu je nejsilněji zastoupeným žánrem. Obvyklým jevem je ale mísení žánrů v jedné promluvě, kdy se vysvětlení dostává do instrukce, které se budu věnovat v později kapitole 9 . 


\section{Reaktivita v promluvách expozičního žánru}

Prvotní zájem o žánrové určení a charakteristiky extenzivní promluvy učitele je dále rozšířen o promluvy jako součást komunikačních sekvencí. $V$ případě analýzy žánrů promluv můžeme na promluvy pohlížet jako na uzavřené segmenty, nyní představím výzkumný záběr směrem $\mathrm{k}$ jejich provázanosti s předchozími i navazujícími promluvami, které by v ideálním případě měly patřit žákům. Při zkoumání extenzivních promluv učitele se vynořily následující otázky: Vznikají extenzivní promluvy učitele pouze v reakci na předchozí žákovské promluvy? Umožňuje extenzivní promluva učitele, aby navazující promluva patřila některému ze žáků? Tato kapitola je tedy věnována reaktivitě promluv, to znamená podobám a možnostem reagování učitele na žáka a žáka na učitele. Zaměřuje se přitom na žánr, se kterým jsem doposud čtenáře seznamovala. Expoziční žánr je převládajícím případem extenzivních promluv učitele v mých datech a předpokládám, že by tento jev mohl celkově fungovat ve výukové komunikaci. Zachycené varianty reaktivity extenzivních promluv budu proto představovat právě na příkladu expozičního žánru. Zároveň platí, že pouze u promluv expozičního žánru jsou zastoupeny všechny z popisovaných variant reaktivity.

Z hlediska struktury IRF se zkoumané extenzivní promluvy často nacházejí na třetí pozici, tedy $\mathrm{F}$ - feedback, netýká se to však zdaleka všech analyzovaných případů. Extenzivní promluvy učitele v mém datovém materiálu se vyskytují také na vstupní pozici, otevírají tedy komunikační sekvenci. $\mathrm{V}$ některých př́ípadech by pro zasazení extenzivních promluv do komunikační struktury bylo třeba vzít v úvahu i jiné, rozšiřující modely struktury. Asociační extenzivní promluva či promluva učitele v průběhu jejich samostatné práce se základní struktuře vymyká (viz dále 8.4.2). V jiných př́ípadech lze uvažovat nad tím, že zkoumané extenzivní promluvy mohou být posuzovány jako př́pad rozvité zpětné vazby, ovšem více samotným rozsahem než kvalitou učitelovy výpovědi. Specifikem extenzivních promluv, jak se jeví v analyzovaném datovém materiálu, je nahrazení funkční zpětné vazby informačně nadbytečným sdělením, které obsah komunikace posouvá směrem, jaký určuje opakovaně učitel.

Př́́klady z dat $\mathrm{v}$ této kapitole nejsou už předkládány jako izolované promluvy (tak jako v mnoha př́padech ilustrujících extenzivní promluvy učitele v předcházející kapitole), ale významné pro pochopení je jejich zasazení do širšího rámce komunikace, která v danou chvíli ve třídě probíhá. Soustředím se stále primárně na učitele, řeč žáků ale poskytuje nezbytný kontext a rámec učitelových promluv. 


\subsection{1}

\section{Extenzivní promluvy v reakci na žáka}

Nejčastější případ extenzivních promluv učitele vyskytující se ve zkoumaných datech je součástí rozhovoru učitele se žáky na dané téma, přičemž sekvence je v tomto případě otevírána učitelem, který pokládá otázku, na niž pochopitelně požaduje odpověd'. Samotná otázka bývá v analyzovaných datech bud' novým podnětem pro žáky za účelem posunu v probíraném tématu, nebo je provázána s předchozí promluvou učitele a přechod ve struktuře komunikace není tak zřetelný. Učitel totiž svou otázkou plynule navazuje v řeči na svou promluvu, v mnoha případech právě extenzivní. Jak známe kupř́kladu z výzkumů komunikačních struktur Samuhelové (1988) nebo Scotta et al. (2006), po učitelově otázce proběhne několik replik, v nichž se obvykle střídá učitel a jeden ze žáků. Schopnost a snad i ochota učitele pracovat s odpověd'mi žáků se různí. I to se ukázalo v předešlých výzkumech výukové komunikace (např. Šed'ová et al., 2012) a následující kategorie ukazují, že pokud odpovědi žáků nejsou přesně takové, jak učitel požaduje, očekává, přebírá záhy kontrolu nad dialogem, ukazuje svou dominanci, řídí stále komunikaci ve třídě, což se projeví ve formě extenzivní promluvy, která svým obsahem pokryje vše, co měli učiteli sdělit žáci a co si př́ípadně učitel dále vybaví a rozhodne do promluvy doplnit. Vnímám zde přitom „pohřbený“ potenciál pokračovat v rozhovoru, snažit se ponechat ještě žákům možnost dospět k odpovědi bez opory rychlejší transmise v extenzivní promluvě učitele. I vzhledem k zachycené strukturaci vyučovací hodiny prostřednictvím témat výuky reprezentovaných pojmy nebo skupinou pojmů, se domnívám, že hlavní příčinou vstupu učitele, který zbrzdí probíhající rozhovor a rozvine se ve formě extenzivní promluvy, je vědomí časového limitu vyučovací hodiny a následně dalších období do konce školního roku, tedy doby, během níž je třeba se všem tématům věnovat. Také proto jsou zkoumané promluvy učitele často přesyceny informacemi, které se učitel „na jeden dech“ snaží žákům předat.

V následující kapitole 7.4.1.1 představím extenzivní promluvy, které se nacházejí na pozici zpětné vazby ve struktuře komunikace. Při zaměření na žánry a jejich charakteristiky ve vztahu k extenzivitě řeči učitele mě ale nezajímá kvalita zpětné vazby ve smyslu hodnocení předcházející žákovské promluvy. Promluvy, které jsou součástí této kapitoly, patří k expozičnímu žánru, žánrově tedy převládá nad evaluací výklad, vysvětlení či komentář. Lze ovšem uvažovat ve shodě se Šed’ovou a Švaříčkem (2010, s. 68) o tom, že se jedná o prrípady „zamlčeného hodnocení", tedy zpětné vazby uzavírající sekvenci výukové komunikace, aniž by učitel do promluvy zahrnul explicitně vyjádřený hodnotící výrok. 


\subsubsection{1}

Je to správně, ale...

Žákova odpověd' na učitelovu otázku, která zcela nesplňuje jeho požadavky, takže se učitel rozhodne uzavřít probíhající rozhovor extenzivní promluvou, nemusí být nesprávná, jak bychom očekávali nejvíce. Naopak, učitel má nejčastěji potřebu doplňovat, rozšiřovat, upravovat to, co sdělil žák po učitelově otázce, i když jeho odpověd' byla vlastně správná. At’ už se jedná o nové téma v hodině, či opakování $\mathrm{z}$ hodin předchozích, otázky pro žáky slouží jakoby jen $\mathrm{k}$ tomu, aby si učitel krátce ujasnil jejich úroveň znalostí, potvrdil si, jak a v čem může dál pokračovat - a to už sám, pustí se do výkladu, přidá upřesňující vysvětlení, zopakuje některé poznatky nebo shrne ty pro něj podstatné. Reaktivita promluv je tedy formálně splněna a učitel žákovskou odpověd' (obvykle stručnou) rozvíjí. Podnětné jsou případy, kdy učitel v takovém okamžiku adekvátně vkládá do své promluvy specifické náměty k tématu, u něhož si ověřil, že základní poznatky už žáci zopakují. Zároveň však v analyzovaných datech lze sledovat extenzivní promluvy, které jsou jen rozsáhlými segmenty v zakotveném schématu IRF struktury. Učitelova strategie v reakci na žákovské odpovědi nepřekračuje pouhé echo, na něž navazuje extenzivní promluva, která nesměřuje k dialogické nadstavbě v komunikaci. 0 rozvoji myšlení při takové komunikaci mezi učitelem a žákem, kdy se žák přizpůsobuje tempu hodiny a ví, že učiteli postačují i jednoslovné odpovědi a dál sděluje opět vše sám, nelze uvažovat.

Žák má mít možnost vysvětlit, jak uvažuje, jak dospěl ke své odpovědi, která by reflektovala, že se u něj tento proces poznávání odehrává (Klapko, in Gulová \& Šíp, 2013). Učitel se však v mých datech spokojí s tím, že alespoň správná odpověd' zaznívá. Namísto jejího dialogického rozvíjení se zapojením i dalších žáků ve snaze ověřit, zda replika byla skutečně výsledkem interpretace poznatků žáky, vstupuje do komunikace učitel a sám odpověd' převypráví.

U: Tak, David tady zmínil moře, bude mít nějaký vliv, jak jsem daleko od moře a na co?

Ž: Srážky.

U: Na srážky, vlhkost. Střední Evropa je na rozhraní oceánského a kontinentálního podnebí. Oceánské podnebí jsme se učili u západní Evropy a ř́kali jsme si, jak ovlivňuje ten oceán, to podnebí. Kontinentální podnebí, samozřejmě čím půjdeme víc na východ, tím bude to podnebí sušší. Pamatujete si na střední Asii, kde jsme si ř́kali, že jsou tam pouště, protože se tam nedostanou srážky, jo? To je ten kontinentální typ podnebí, takže toto dělá vždycky největší problém, co je to oceánské a co to je kontinentální, nebo já nevím vnitrozemské podnebí. 
U: Představte si, jak to vypadá na pobřeží, jaké tam bude léto, jaká tam bude zima, Adri.

Ž: To je severní moře, to je studené.

U: No určitě, ted' nerozlišujeme, jestli to moře je teplé, nebo studené, ale jaký to má vliv na ty srážky. Léto bude?

Ž: Deštivé.

U: Deštivé a teplotama spíš chladnější a zima?

Ž: Mírná.

U: Zima bude mírná a zase bude docela deštivá, jo? Takže, ten oceánský typ znamená, že to podnebí je vlhké a jsou tam mírné zimy a chladnější léta. Děcka, ten oceán totiž neustále v létě ochlazuje, v zimě otepluje. Když půjdeme na, do vnitrozemí, čím budem dál od toho oceánu, tím menší vliv toho oceánu bude. Tak bude samozřejmě mín srážek, čili kontinentální podnebí, nebo vnitrozemské podnební je suché a jsou tady horká léta a ledové zimy. Protože v létě se ta pevnina dlouho prohřívá a nic ji neochlazuje, takže se víc prohřeje a v zimě se zase víc promrzne, prochladí, jo? Čili jsou tam obrovské rozdíly mezi teplotami. V podstatě my v České Republice máme to štěstí, že jsme na rozhraní, já si myslím, že máme takové jako, velmi př́jemné je to počasí. V zimě zimu máme, v létě teplo máme. Nemůžeme říct, že by u nás bylo celý rok teplo, nebo celý rok zima. Tak a srážky se během roku docela mění, pravidelně. (Adéla, 7. ročník, zeměpis)

Tématem prezentované ukázky je střední Evropa a konkrétně podtématem její podnebí. Na první otázku učitele odpovídá žák jediným slovem a tento způsob komunikace žáka s učitelem se následně nemění. Jedná se také o typickou výměnu, kdy se učitelka spokojí s jednoslovnou odpovědí, která je správná, ale pro žáky rozhodně nepředstavuje složitou myšlenkovou operaci. Takto stručné vyjádření učitel ale rychle doplní všemi informacemi, které by později mohl po žácích vyžadovat v prověrkách jejich znalostí, protože patří k výkladu nového učiva v rámci této vyučovací hodiny. Obsahově volněji nastavená otázka formálně vyjádřená jako pokyn „Představte si, ..."nabízí žákům jen zdánlivou možnost vyjádřit se mimo učitelčiny požadavky na odpověd'. Ty nejsou naplněny, což učitelka jasně sděluje a dále tedy opět nabízí jen stručné doplnění připravené otázky. Její správné zodpovězení je v tu chvíli už mnohem pravděpodobnější a čas výuky ušetřen.

Podobný případ ilustruje ukázka z hodiny českého jazyka (literatury), kde opět učitel použije otázky jen k lehkému „nat'uknutí“ tématu spolu s žáky, po jejich minimalistických odpovědích je rozvádí vlastními promluvami, aby opakování ukotvil. Typické je rovněž echo žákovských odpovědí a specificky u tohoto učitele také známá chyba - kladení mnohonásobných otázek (Gavora, 2005), přičemž na 
jednu sám učitel odpovídá. Domnívám se, že žáci jsou na tento zpưsob komunikace u učitelů natolik zvyklí, že sami nemají potřebu a důvod angažovat se alespoň delšími replikami.

U: Antickou literaturu jsme dělali. To bylo první, první typ, nebo první druh té velké oblasti literatury eee středověk, starověk, novověk?

Ž1: Středověk?

Ž2: Antické.

U: A co je antická literatura? Antika byla v eee starověku, středověku nebo novověku?

Ž: Starověk.

U: Ve starověku. Začínáme v úplně těch nejstarších dobách, takže děláme starověkou literaturu, Jessico... vid'? Starověkou literaturu, eee, ř́kali jsme si, že pro nás jsou to nejdůležitější dvě základní období nebo to základní typy té literatury podle toho kde se... eee vytvářela ta literatura antická. Co to je antika? Co to je za oblast? Co označujeme jako antiku, antické období? Jaké dva státy?(2s) Starověké Řecko a Řím. A u té antické literatury vzpomenete si na něco, co jsme si o ní ŕíkali? Ž: Píše se o bozích.

U: Hlavní téma, super, jsou tedy bohové a my jsme si ř́kali něco o ve starověké literatuře, jak se lišila třeba o té současné?

Ž: (potichu) Že museli opisovat.

U: Prosím?

Ž. Že opisovali hodně.

U: Že hodně opisovali, že se až tolik neliší, nebo liší se to od literatury, ale když si představím písemky a testy ve škole tak ono se opisuje stále a pořád, ale to bylo samozřejmě opisování literatury eee takže v podstatě nešlo o nějakou originalitu, vůbec nebylo nic špatného na tom, když eee když autor teda napsal něco, co už dávno napsáno bylo. A jací byli ti autoři? (Adam, český jazyk, 7. ročník)

Stejně jako $\mathrm{v}$ dalších případech zachycených $\mathrm{v}$ datech, i v promluvách $\mathrm{z}$ této ukázky komunikace mezi učitelem Adamem a vybraným žákem nacházím opakující se prvek, kdy učitel v reakci na žáka začíná potvrzujícím echem jeho odpovědi.

Po správném zodpovězení otázky žákem se učitel může do svého vysvětlení i trochu zaplést. V následujícím př́ípadu, kdy učitel upřesňuje, co chtěl slyšet a co je na tom zvláštního, odskakuje v asociacích k plánované písemné práci a žáky navíc naprosto demotivuje konstatováním, že na rozdíl od Macourka se o „bezvadné vyprávění" snažit nemohou a ani nemají. 
U: Ehm, zapomněl jsem vás upozornit na to... nebo vlastně jsem to možná udělal schválně, v čem je to zvláštní, všiml si někdo, v čem je to vypravování zvláštní? (Nikdo neodpovídá)

U: Tak kdo třeba? Kubo?

K: Že tam je jedna věta.

U: Celé vypravování je psané jednou větou. Jo, všimli jste si toho? Začíná to velkým písmenem, tečka je až úplně na konci...samozřejmě, tím vám neříkám, že celou slohovku čtvrtletní budete psát jednou větou...tohle, co jste viděli, je od Macourka, ten umí vyprávět bezvadně, vy se o to zatím radši ještě nepokoušejte...vypravovat jednou větou, spíš to bude chyba, než že by to byla výhoda...ale třeba se k tomu taky někdy dopracujeme. A chtěl jsem se zeptat ještě na jednu věc ...když se podíváte na úkol pět, máme vyhledat antonyma, chtěl jsem se zeptat, co to je, ale je to tam napsané...co to jsou antonyma teda? Aniž byste...aniž byste tam koukali. (Adam, 6. ročník, český jazyk)

Zdá se, že učitelé často vyžadují, at' vědomě či podvědomě, aby odpovědi na jejich otázky byly skutečně přesně takové, na které potřebují přesně navázat. Přenášejí do komunikace schéma celé plánované hodiny, proto do ní musí zapadnout i repliky žáků. Pokusy o diskuzi se žáky nacházíme v hodinách jen výjimečně. I tady ale učitel dokáže pracovat s odpověd'mi žáků, které jsou možnými správnými odpověd'mi, jen po určitou dobu a nakonec se ujímá slova sám a žákům problematiku podrobně vysvětluje.

U: Proč myslíte, že takové, Petře, proč myslíš, že takové značky tady máme. Proč by jsme tam nemohli napsat tisíc, tři tisíce kilogramů. A z čeho to vyplývá, že takovou jednotku hmotnosti pořád ještě používáme? S čím to tak může souviset, Kubo.

Ž1: Protože auta třeba neváží míň než tunu.

U: Auta... některý váží míň než tunu, to je jedna věc a druhá věc je, že jako, ten, ta otázka je, proč vlastně používáme tunu, proč nepoužíváme tři tisíce kilogramů. Ž1: Protože auto váží tři tuny.

U: No ale proč, proč to teda, když vážíme sebe na kilogram, proč nevážím auta na kilogramy. Vendi.

Ž2: (odpovídá jiná žačka než vyvolaná) Protože třeba kdyby jel kamioňák, kamioňák a měl třeba čtyři tuny a přepočítal se o jednu nulu, tak by tam vjel a ten most se jakoby zřítí.

U: Jako, že by tam, že by tam jel nějakou rychlostí, takže by tam byly ty, když 
to vemu takto, tak by ta značka vypadala (kreslí ji na tabuli) takhle. Je pravda, ఏana má pravdu v tom, že když bych jel tou rychlostí, tak bych tam mohl nějakou tu nulu, mohl určitě minout. To je praktická věc, ale ta druhá věc, proč to asi používáme je?

Ž: Protože ty čísla jsou veliký.

U: To je druhá praktická věc. Správně. Ty některý ty čísla by byly veliký. To byla ta věc praktická. A co takhle nemůže za to, nemůžou za to ti naši předci? Že tohle začali používat dřiv? To stejný s tím metrickým centem. Ve stavebnictví typická jednotka jo, sto kilogramů je jeden metrák, jo. Takže historicky se tyhlencty jednotky používaly a těm lidem seděly, tak je používáme dál a v některých těch obdobích se budou pořád používat jako třeba zrovna to stavebnictví nebo ta doprava, jo. Tak jenom, abyste věděli. Hlavně kamioňáci až budete jezdit na ty mosty, ne že mi to budete prejeíždět, byste to zničili. Jo. (Martin, 6. ročník, fyzika)

Extenzivní promluva učitele, v následující ukázce doplněná navíc jasnou indikací, že jde o nadbytečné opakování toho, co již v předmětu zaznělo, se objevuje v situaci, kdy se správné odpovědi žáci doberou až po několika špatných.

U: Tak, prosím vás. Pojd'me se vrátit k tomu textu na chvilku. Kde se bere ten textilní průmysl? V tom chladnu. S čím to zase souvisí?

Ž: Z hor.

U: Z hor, průmysl se bere $\mathrm{z}$ hor, hmmm.

Ž: Z těch zvířat.

U: Ze zvířat.

Ž: Kožešiny.

U: A co jsme si říkali, když jsme se učili ovce, tak dobře no, tak pojd'me si najít mapu zemědělství, strana dvacet pět, to máte hned před tím, kolik těch oveček vás tam prosím vás vidíte?

Ž: Žádné.

U: Kde jsme si říkali, že je soustředěný chov ovcí v České Republice?

Ž: Beskydy.

U: Beskydy, to je hodně velká dálka. Tak to asi nebude souviset se zpracováním vlny, takže něco jiného.

Ž: Len.

U: Len, my jsme si přece ř́kkali, že v těch podhorských oblastech lidé dřive pěstovali len a zpracovávali, vždyt'jsem vám tady připomínala, ještějsem to zmiňovala film 
Krakonoš a lyžníci, tam měli v těch staveních ty stavy, jo? Takže oni tam vlastně zpracovávají z, to je tradice. Potom samozřejmě vznikaly nějaké ty jednotlivé typy manufaktury, že jo, ale nějaké ty závody řemeslné, pak po tom další. Ale pozor, ríkali jsme si, že jsou to spíše menší závody a taky jsme ale říkali, že jejich výroba je v útlumu, protože?

Opět se setkáváme s jednoslovnými replikami žáků. Tento aspekt v řeči žáků je však zásadně v rozporu s požadavkem aktivního konstruování významu v přírodovědných předmětech tak, aby žáci jen nesdělovali prázdná slova bez vazby na širší tematický koncept poznatků (Pimentel \& McNeill, 2013). Přitom stejná učitelka v jiné ze zaznamenaných hodin sama těmto žákům vytýká, že:

U:...mně se teda nelíbí jedna věc, ale to nebylo jenom kluci k vám k té prezentaci. Děcka, snažte se používat věty, které mají podnět a přísudek, jo? U vás ta věta vypadá cestovní ruch, zámky, Pecka, ee hrady Pecka a první bylo?

Ž: Kost.

U: Kost. Jo, kdyby jste řekli třeba cílem cestovního ruchu, nebo střediska cestovního ruchu jsou, když mluvíte o městech, ale jakože vy říkáte hesla. Přesně takhle jsem si všimla, třeba když se čte ráno rozhlas, někteří žáci čtou rozhlas, netvoři věty, ale prostě čtou heslovitě, co bude, u té prezentace by tak být nemělo. Takže ty prezentace děláme nejenom $k$ tomu, aby tady jsme si řekli... něco o tom kraji, ale abyste se taky naučili mluvit. Tak, co byste chtěli třeba, co jste viděli, upoutávky navštívit, nebo co jste navštívili, zkusme si říct, jestli někdo něco navštívil.

Ž: Hrad v Ratibořicích.

U: Tak, ale Ratibořice všichni známe odněkud, ne? Ř́ká vám něco třeba Staré bělidlo?

Ž: Jo, Babička.

U: Babička a kde žila kněžna?

Ž: Na zámku.

U: Na zámku, a jaký to byl zámek?

Ž: Ratibořický.

U: Ratibořický, takže tento kraj popisuje právě Božena Němcová v Babičce. No tak, co ještě... tam jsem teda také byla a byla jsem tam v květnu možná touto dobou, tam každý rok teda možná pořád ještě v květnu jeden týden v roce nějaký ochotnický soubor, nevím už ze kterého města, jestli třeba znáte, ale nevím, provází tím babiččiným údolím a přivítá vás tam. A je tam vlastně Babička je tam, prostě jsou v kostýmech těch postav z Babičky a provázejí vás tím údolím, kam jdete, 
totiž samozrejmějdete do domečku, kde žila Babička, já nevím jdete do mlýna. Jo? Procházíte, oni, oni vás tam vlastně hrají takové malé scénky z té Babičky, anebo vás jenom provázejí, odpovídají na otázky, které máte. Je to celé v tom stylu devatenáctého století ...(nejde rozumět)... takže je to takové trošičku sehrané nebo předčítají z té knížky něco a je to takové interaktivní. Tak nic, pojd'me dál, co ještě by vás třeba napadlo v tomto kraji podle toho, co jsme slyšeli, je něčím zajímavý ten kraj? (Adéla, 8. ročník, zeměpis)

Apel na prezentační dovednosti a tím i propojení hodiny zeměpisu s komunikační výchovou by jistě byl žádoucí, pokud by také učitelka v rozhovorech se třídou nabízela jiné možnosti odpovědí než jedno- či dvouslovné a své žáky vedla $\mathrm{k}$ tomu, aby se vůbec $\mathrm{v}$ celých větách vyjadřovat mohli. Její podněty jsou ovšem formulovány tak, že skutečně stačí jen vybavit si či odhadnout slovo či slovní spojení a rozhovor rychle pokračuje. Důvodem je rovněž celkově dominantní komunikační styl učitelky.

\subsubsection{2}

\section{Absence požadované odpovědi}

V předchozí kapitole jsem popsala extenzivní promluvy jako vstupy učitele do rozhovoru se žáky v situacích, kdy žáci na učitelovy otázky odpovídají sice správně, ale přesto má učitel potřebu do rozhovoru ještě připojit další vysvětlení, sdělení či souhrn informací. Jakmile se v rozhovoru projeví, že žáci správnou odpověd' neznají, je extenzivní promluva učitele také častým jevem, který podle mého názoru odpovídá pocit’ované nutnosti zvládnout téma výuky ve vymezeném časovém úseku. Je to stále učitel, kdo komunikaci řídí a žáci jsou si toho vědomi a na tuto „hru“ přistupují.

U: Takže to máme ty biologické a pak máme sociální, ty budou získané.

Ž: Vylučování.

U: Vylučování třeba. Ehm, sociální, Kristýnko... ty jsou získané.

Žž: (smích)

U: Nevím, jestli u vás to bude úplně platit, ale jednou z takových sociální potřeb může být potréeba vzdělání (smích třídy), to vám dojde až pozdějic. Vzdělání, pak může být potřeba radost (píše na tabuli), mít radost, čili radosti, štěstí, lásky a tak dále a tak dále. Tak, to máme jeden takový úkol, k těm potrebám, a abychom je měly kompletní, tak si budeme muset ted'ka něco namalovat, nebojte se, nebude to 
žádný veliký obrázek, bude to jenom tak na řádky taková pyramidka. Tak napište si na další řádek, hlavně zkuste nezkomolit to jméno... (Jakub, 8. ročník, výchova kobčanství)

Odpovědí učitele na nesprávně uvedenou sociální potřebu je doslovné zopakování chybného výroku s ironickým hlasovým a mimickým výrazem a následný rychlý výčet adekvátních možností uvedený opět s ironií, která nezaznívá ve výuce poprvé a patří $k$ typickým projevům daného učitele. Takto tř́ída stráví nad pojmem sociální potřeby jen jednu minutu a je možné pokračovat dále k tématu potřeb celkově. Pokud by učitel jednak pracoval nápaditěji s chybou žákyně, ale především se dále snažil získat od třídy vhodné př́iklady získaných potřeb, strávil by nad touto částí tématu delší časový úsek. To je však pro něj nevýhodné.

U: Tak děcka, zkusme tedy odsud vytáhnout to nejdůležitější. Jaké je osídlení toho Libereckého kraje, jak byste ho charakterizovali? Dvěma větami, nemůžeme si napsat nějaký velký odstavec, ale co byste odsud vypíchli jako informaci, která třeba není typická, srovnejme se Zlínským krajem, jo? (6s) Nic? (4s) Je tam stejné obyvatelstvo jako tady u nás?

Ž: Ne.

U: V čem se liší?(6s)

U: Děcka je to pohraniční oblast, my jsme taky pohraniční oblast dneska už, náš kraj taky sousedí s cizím státem, se Slovenskem, ale přesto se v něčem lišíme.

Ž: Těch cizinců.

U: Prosím?

Ž: Že my máme taky dost těch... cizinců, no prostě.

U: Je to osídlení stejné jako tady opravdu? V čem se liší?

Ž: Je tam více obyvatel.

U: Více obyvatel? Zlínský kraj má spíše teda víc obyvatel... to bude záležet asi hodně na... na povrchu, ale co ta menšina nějaká?

Ž: Poláci.

Ž: Němci.

U: Tam jsou Němci, tam je velká německá menšina, u nás tady nepotkáte.

Ž: Slovák.

U: Tady budou spíš Slováci, což souvisí s tím, že jako Zlínský kraj sousedí se Slovenskem a oni tam sousedís Německem a děcka, tady to pohraničí bylo kolonizováno těmi Němci, tam byla dř́v spíš většina těch Němcủ, jo mnohem víc, dneska už ne 
teda, jo asi to bude souviset is odsunem Němců, ale prostě ta menšina Německa je tam pořád výrazná, jo a tam taky když pojede tím směrem, tak už třeba jak se blížíte $k$ hranicím, tak uvidíte třeba německé názvy, to tady nevidíte, proč, jo? Takže tady, tady vlastně ten kraj je takový jakoby, jsou tam důsledky takového poněmčení. Tak hustota zalidnění je nerovnoměrná a to souvisí samozřejměs tím povrchem a souvisí to s tím, že to byla, je pohraniční oblast a do toho pohraničí se lidé moc nehrnou. My jsme ale minule probírali kraj, kde teda byla taková výjimka a na to že to je pohraniční kraj, je tam vysoká hustota zalidnění, nebo vůbec vysoké, velký počet obyvatel, ale souviselo to s tím, že to je významná průmyslová oblast. (Adéla, 8. ročník, zeměpis)

Učitelka zeměpisu se v osmé třídě pokouší získat od žáků odpověd' spočívající v komparaci obyvatelstva dvou oblastí. Její projev je tentokrát netypický v tom, že ponechává žákům delší čas na promyšlení odpovědi, na otázku nenabaluje další, ale opakuje ji stále dokola. Tím se však také žákům uzavírá možnost o odpovědi diskutovat, je zřetelné, že učitelka očekává konkrétní odpověd', na kterou žáci hned nepřichází. Nakonec se rozhodne zacílit ještě jednu otázku na požadovanou správnou odpověd'. Žáci konečně zkoušejí odpovídat a jeden z nich uspěje, učitelka pokus uzavírá vysvětlením, jaké obsahuje několik informačních částí, mezi kterými v promluvě přepíná.

Dosavadní př́íklady extenzivních promluv učitele v této kapitole se týkají reaktivity na repliky žáků jako součásti předpokládaného průběhu komunikace s učitelem nastaveným scénářem. Reaktivita je mechanická, zakotvená v opakující se podobě ovlivněné také převládajícími expozičními žánry vyučovacích hodin a komunikačním stylem učitele. Provázanost promluv je tedy výsledkem předpokladu a požadavku učitele na sdělení potvrzující získané poznatky ze strany žáků. Extenzivní promluvy jsou učitelem navíc formulovány tak, že neumožňují žákům reagovat ze své podstaty, obsahují totiž množství informací, na jejichž zpracování žáci potřebují více času a další je nutný pro produkci jejich vlastních vyjádření souvisejících s předchozí učitelovou promluvou. Případy, kdy extenzivní promluvy učitele jsou reakcí na komunikační vstup žáka mimo očekávaný scénář, ukazuje následující kapitola.

\subsubsection{3}

\section{Neočekávaný vstup žáka}

I když výskyt extenzivních promluv učitele souvisí především s jeho komunikačním stylem a způsobem, jak pracuje ve výuce s tématem, které se snaží žákům 
prezentovat, předat, nastávají situace, kdy se učitel „rozpovídá“ na základě iniciace žáka. Promluv žáků, které by nebyly jen vyžádanou replikou na výzvu učitele, nacházím málo. Dále pak v některých př́padech učitel komentáře ignoruje či doprovází jen neverbálně, mnohdy je to pochopitelné, když se jedná například o cílené provokace. A tak jen občas lze extenzivní promluvu učitele posoudit jako takovou, která by bez příspěvku žáka v hodině vůbec nenastala, ale naštěstí ještě „nevymřela“.

\section{(hlásí se žákyně)}

U: Terko, co chceš?

Ž: Kdysi my jsme se tak porovnávali, jako myslím celá tř́da, to bylo v páté třídě na škole $v$ prŕrodě. Tam byla taková deska a tam jsme si všichni stoupli a měli jsme to všichni vyvážit, aby ta deska nebyla na zemi.

U: Jasně. A tam jste, správně si řekla, že jste se tam porovnávali, ale spíš ste tam hledali to rozložení těch různých lidí na tom na té desce tak, aby ta výsledná síla pưsobila na střed té desky, ve které byla nějaká pružinka, předpokládám. Jo je to takhle, to co myslím. Jo. A vlastně když si v tom, tak musel stoupnout zároveň i na pravou, někdo další pravděpodobně na levou a pak se to vyrovnalo, jo. Když si stoupl jenom trošku někam jinak, tak už se to zase takhle otáčí. Takže to byla dobrá pomůcka na takovou balanční, na hledání právě toho těžištěe, když zatížíte nějaké těleso. Když jste si na to stoupli, tak ste se stali součástí té desky. Když jste z toho odešli, tak deska zůstala zase rovná. (Martin, 6. ročník, fyzika)

Už samotná výzva učitele, který se ptá žákyně, co chce, naznačuje, že i pro učitele tato situace není běžná. Př́klad, který si na základě zkušenosti žákyně vybavila, ukazuje na porozumění obsahu učiva, který v tu chvíli učitel tř́íě předává. Jeho komunikační vstup poněkud "neučesaně“ přibližuje princip těžiště ostatním žákủm. Podobně jako v běžné mezilidské komunikaci mimo dané prostředí školní třídy, kdy rozvíjíme předchozí repliku komunikačního partnera tak, abychom stočili pozornost na nás, i zde učitel využívá iniciativu žákyně k tomu, aby převzal řízení komunikace.

Následující úryvek z hodiny matematiky přináší vstup žáka, který diskutuje s učitelkou vlastní pohled na zadání úkolu. Jeho možnost učitelka neakceptuje, i když se žák snaží ji prosadit. Extenzivní promluva slouží ke zdůvodnění názoru učitelky na jediné správné východisko pro řešení úkolu. Žáky při příštích pokusech o projevení názoru může ale odradit, že snaha o diskuzi nebyla učitelem nijak oceněna. 
U: Tak jako představme si děcka, že ten sloup nestojí někde u zdi, jo? Sloup je přístupný ze všech stran. Tak David, já teda vidím tady stěnu přední, boční samozřejmě je tam nějaká ta zadní a David říká z vrchu.

Ž: To není stěna.

U: To je teda podstava, ale neumím si představit, komu by se vyplatilo si tam umist'ovat reklamní plochu, protože kdo by viděl tu reklamu?

Ž: Z letadla třeba.

U: Z letadla, to by musel lítat těsně nad tím, protože...

Ž: Z okna, z okna.

U: Něco jiného je, ně... něco jiného je mít nějaký dobrý, nějakou velikánskou budovu, která má střechu, tak tam by se dalo něco umístit, ale sloup je docel malý na to že, to byste nedo, neviděli. Vy u toho sloupu musíte stát, ani z okna bys nedohlédl co na té reklamě je, to bys musel stát, být úplně prímo, bydlet za tím sloupem. Takže myslím si, že tady je jasně naznačeno, že reklamní plocha je pouze na plášti toho hranolu, jo? No a podstava ta už vůbec nemůže být využitelná, čili jenom plášt' toho hranolu použijeme jako reklamní plochu, jo? Tady dala by se použít střecha, ale musela by to být asi mnohem větší plocha. Když se zamyslíte, že máte firmu, chcete zaplatit reklamu, ta reklama není zadarmo, tak chcete, aby tu reklamu někdo viděl. Jo, na takovém malém sloupu byste z vrchu nic nepřečetli, potřebujete větší plochu. Jo na střeše prosím, tak. (Adéla, 7. ročník, matematika)

Výzkum Myhillové (2006) potvrzoval dominanci učitele při hromadné výuce (zahrnoval přitom 18 epizod hromadné výuky z 1. i 2. stupně základní školy, jedna epizoda měla cca 15 minut). Zajímavé bylo její zjištění, že otázka položená žákem vedla k ukončení interakční sekvence (jako jednotce analýzy v jejím postupu), dále ji zřídka zahájila nebo dokonce iniciovala). Celkově se opakoval konvenční vzorec diskurzu s učitelovou kontrolou řečového scénáře.

Případ, kdy neočekávaný vstup žáka do komunikace se učiteli nehodí, a ten si tak potvrzuje, že příště bude čekat jen na vyzvání učitele, ilustruje následující ukázka z hodiny přírodopisu.

U: Tak, my se vrátíme k feromonům a pak, napište si k tomu, že (diktuje) člověk toho využívá, člověk, této znalosti využívá (4s) a do lesů umist'uje lapače, feromonové lapače (8s), je to takové trubka, někdy jste možná viděli, oplocená Ž: My tam ...

U: Feromonové lapače, takže člověk toho využívá...

Žák Petr: My tam máme takové, na zídce takové dřevo, tam...(kreslí ve vzduchu rukama, jak to vypadá) 
U: A umist'uje, počkej, Pet'o, až, do lesa feromonové lapače.(konec diktátu) Ten lapač slouží, že vylučuje stejnou látku jako ta samička, takže všichni samečci se v lese zblázní a ze čtyř kilometrů přiletí tady do té, na tu past, která je dokola oblepená lepem, takže se všichni samečci přilepí a samičky můžou vylučovat, co chtějí, nikdo tam za nima nepřiletí, protože samečci jsou nalepení na feromonový lapač. Děláme to právě proti lýkožroutu, aby se nám v lese nerozmnožil, nepřemnožil a my jsme zachránili ty smrkové lesy před jeho požerem.

U: ukazuje na žáka

Ž: Já nic, vy jste to potom vysvětlila. (Dana, 6. ročník, přírodopis)

Žák Petr už lapače v lese dobře sám zná a chtěl to ostatním ve třídě popsat, vysvětlit. Učitelka ale princip fungování vysvětluje sama, když potom žák dostane konečně slovo, konstatuje zcela výstižně, že vše už bylo řečeno. V rámci managementu třídy je pochopitelná její snaha dokončit sdělení informací k zápisu do sešitu. Před samotnou vysvětlující promluvou („Ten lapač slouží...”) se ale mohla vrátit ke vstupu žáka.

Typickým prvkem extenzivních promluv učitele popisovaných v této kapitole je jejich zakončení otázkou či pokynem, která už žáky přenáší k další části probíraného tématu, případně je to opět učitel, který po krátké odmlce přichází s iniciací v komunikaci, která však obvykle nestaví na tom, co se v předchozí promluvě žáci dozvěděli. Žáci jsou tedy postaveni do role pasivních příjemců, extenzivní promluvy učitele jim poskytují odkazy na dříve sdělovaný obsah či další souvislosti mezi jevy, jimž by měli porozumět, ale nemají potenciál, aby přinesly reakci na straně žáků.

\subsection{2}

\section{Od reakce na žáka k vlastní asociaci}

Předchozí případy promluv se týkaly komunikačních situací ve třídě, kdy učitel reaguje extenzivně na požadovanou nebo chybějící odpověd' žáka, případně na jeho neočekávaný vstup do komunikace ve třídě. V této kapitole již opustíme případy běžné zpětné vazby učitele. Extenzivita je způsobena posunem k novému tématu, i když tedy v myšlenkách učitele zcela souvisejícího s předchozími promluvami. Extenzivní řeč učitele je ovlivněna rovněž jeho asociovanými promluvami, tedy takovými, kdy do výkladu či instrukce vpadne náhlá myšlenka, kterou si učitel nechce ponechat pro sebe. Asociace je vázána na situace ve výuce v dané třídě, často propojuje aktuální vyučovací hodinu s předchozími nebo těmi, které teprve 
následovat budou. Ačkoliv kontext promluvy je svázán situačně s přítomností žáků, pro které je určena, učitel rozšiřuje promluvu mimo předchozí repliky probíhající komunikace. Provázanost promluv je nadstavbou pouhé reakce učitele na předchozí repliky žáků, souvisí ale se zkušeností učitele s konkrétními žáky, které má v tu chvíli před sebou. Učitel tento „odskok“ od probíraného tématu označuje i formou vyjádření.

U: Určitě začneme v Liberci dobře. Jaký průmysl děcka je, jo, to jsem si vzpomněla, co to znamená, když se zeptám, jaký je tam převažující průmysl. Tak jestliže máte vyznačené město kolečkem, to kolečko je dále rozdělené, může a nemusí být, tak převažující znamená, že v tom kolečku převažuje, jo to je nějaký kruhový diagram. Jestliže je jednobarevné, no tak to je úplně stoprocentní převaha a když já se ptám tam na Moravskoslezský kraj na nějaké, na nějaký strojnický průmysl a vy mi tam napíšete město, kde je teda malinký klínek, přitom tam máte několik měst jenom modrých, to jste mě teda jako nemile překvapili. Jestliže se ptám na město $s$ převažujícím strojírenským průmyslem tak hledám pokud možno celé modré kolečko. Když není celé modré, tak aspoň takové, které má toto modré a tady je něco jiného, v té malé výseči. Jo, ale ne, že se tam objeví takový, takovýto ždibínek nějakého strojírenského průmyslu a vy tam budete to psát. Převažujícíje, že bud'je celé anebo třeba většina anebo je to rozdělené na tři průmysly a nějaký převažuje a dva jsou, jo, nějak se tam vyskytují, takže podívejme se na to eee na ten Liberec. Jaký průmysl tam převažuje? (Adéla, 8. ročník, zeměpis)

Učitel v promluvách obvykle plynule naváže na učivo, nedojde tak k „prolomení bariéry“ řízení komunikace učitelem.

Extenzivní promluvy učitele, v nichž asociačně reaguje na pocit'ovanou potřebu poučit žáky o prožitých zkušenostech, často obsahují apel na smysl pro povinnost, snahu ukázat žákům správnou cestu na základě toho, co učitel už vnímá s odstupem času jako důležité. V tomto případě se ale poučení vztahuje především k povinnostem nebo žádoucím dovednostem žáka ve škole. Apel vyjadřuje především negativní postoj učitele ke komentované problematice.

U: Jo, já to mám u sebe napsané, počkej. Děcka já jsem kdysi, ještě na vysoké škole doučovala, poslouchejte, ve třet'áku a ve čtvrtáku z matiky, na elektro, na průmyslovce a, Vend'o, oni ho nepustili k maturitě, protože neodevzdal nějakou práci. Takže jenom chci říct, že jestliže si neplníte referáty, však ho splním jindy, on se nedostal, oni ho nepustili k maturitě ve čtvrt'áku a on skončil, on si dodělával maturitu potom později a mimochodem jeho maminka už v té době byla poměrně vysoko ve Zlíně postavená politicky a víte, co udělala? Vzala ho z té školy, dala ho teda na učňák, 
on si udělal výuční list a pak si udělal maturitu, ve čtvrt’áku na průmyslovce. Takže hlavně flákejte. (Adéla, 8. ročník, zeměpis)

Učitelka explicitně upozorňuje na důležitost sdělení, které navíc ukončuje ironií, jakou jsou žáci 8. ročníku zřejmě schopni rozpoznat. Pro tuto učitelku je to jeden z typických projevů, prostředkem pro udržení pozornosti při sděleních. Domnívám se, že pokud není ironie namířena na konkrétního žáka, lze ji v komunikaci učitele se třídou akceptovat. Srovnání pozice žáka na základní škole a studenta středoškoláka je však pro třídu příliš vzdálené.

Zajímavý je vstup učitele v hodině občanské výchovy, kdy se během výkladu dotkne aplikace tématu učiva o schopnostech jako součásti inteligence na zkušenost se schopností učit se konkrétně u žáků v dané třídě.

U: Já jsem pochopil, že to není páternoster nebo něco takového... Takže schopnost rozlišit podstatné od nepodstatného. Když se třeba učíte, takže zase to může třeba souviset s tím, abyste se neučili nesmysl, ale učili se jenom to, co je dưležité. Podstatné důležité, od nedůležitého. Rozlišit podstatné od nepodstatného. Nebo důležité od nedůležitého. Když si třeba přečtete nějaký text, a to je jeden z problémů dnešního českého školství a vás, tak špatně, nebo když pracujete s učebnicí, tak to na vás úplně jde strašně vidět, ne že neříkám, že nejste inteligentní, ale že špatně pracujete s tím textem a nedokážete si z té učebnice vytáhnout, co je dưležité, takže na tom ještě do konce roku musíme zapracovat. Podstatno nepodstatné, že z tama nedokážete vytáhnout ty dvě, tři dưležité informace a babráte se tam v detailech, které nejsou až tak podstatné. (2s) Ale zas někdo by taky mohl říct, že to třeba dávat do písemky, třeba není úplně dưležité. Takže nebojte se, nejste v tom sami ... to má tak úplně každý. Tak další a poslední co si tam dáme je schopnost přizpưsobit se... okolnostem.... (Jakub, 8. ročník, výchova k občanství)

V tomto případě mohl rozšířený vstup působit jako vítaná změna v přístupu učitele k výkladu a vysvětlování. Celá vyučovací hodina se totiž opírá o několik pojmů, přičemž nejen žáci, ale i já v roli pozorovatele jsme na konci hodiny ztěžka potlačovali otupělost z přívalu suše podávaných informací. Promluva propojující dané učivo s aktuálně vnímanými obtížemi žáků přitom nabízí možnost smířit se s menším objemem probraných pojmů a zkusit asociované téma s žáky prodiskutovat. 


\subsection{3}

\section{Vyvolání reakce žáka}

Případ, kdy jsou v promluvě učitele rozšiřovány obzory, se téměř vždy týká poznatků učitele předávaných žákům, opačné situace, kdy by naopak učitel prostřednictvím neočekávaného sdělení žáka získal nové informace, pohled na prezentované téma a komunikace mezi nimi by byla v tomto směru plnohodnotně oboustranná, se ve zkoumaných hodinách neobjevila. Na druhou stranu můžeme prríčinu výskytu extenzivní promluvy ve výuce, kdy se učitel rozpovídá o něčem, co souvisí s probíraným tématem a co je určitým bonusem v poznatcích, považovat za pozitivní pro motivaci žáků k tématu, oživení předávaného obsahu. Zároveň se jedná o poměrně výjimečný případ, kdy se po ukončení učitelovy extenzivní promluvy žáci rozhodují vstoupit do komunikace s učitelem sami bez vyzvání.

Extenzivní promluvy nejsou v tomto případě na pozici zpětné vazby, pokud bychom se je snažili zařadit do běžně užívané struktury výukové komunikace IRE. Jedná se naopak o vstupní, tedy iniciační promluvy přinášejí novou sekvenci.

U: „V př́padě, že se potřebujete doma zbavit mravenců, tak si tam napište pomoc, když doma vám budou běhat mravenci, ukradnete ve škole kř́́du, nasypete jim to na ty cestičky, ono se to zneutralizuje a ty mravenci jsou zmatení. Nanesou to do mraveniště a oni se začnou chovat zmateně, že nekrmí královnu, prostě tam dojde k takovému zmatku, že se seberou a odstěhují se od vás, vy jim tu kyselinu mravenčí zlikvidujete kř́́dou ze školy, vápencem, nebo něčím podobným jo?"

Ž: „Mamka mi říkala, že chodili na procházky do lesa a vždycky tam našli nějaké mraveniště, tak na to vždycky hodili kapesník nebo co, aby se to napustilo těma štávama a oni si to pak vzali." (Dana, 6. ročník, př́rodopis)

Extenzivní, avšak pro žáky zajímavá promluva, z níž není nutné pořizovat zápis do sešitu z důvodu učení se doma k prověřování vědomostí učitelem, je pocit’ovaným odlehčením a toto uvolnění signalizuje žákům, že by se mohli do komunikace připojit. Učitelka navíc osobitým neformálním komunikačním stylem, kdy používá často nespisovné či nářeční prvky, barvitý popis a humor (,...ukradnete ve škole křídu“), i když z výchovného hlediska nevhodný, podporuje atmosféru ve třídě, která žáky ve spontánních reakcích neomezuje. Zároveň je však učitelka schopná udržovat verbálními i neverbálními prostředky kázeň ve třídě. 
Jedním z důvodů vstupu extenzivní promluvy učitele do probíhajícího dialogu s žáky na dané téma může být tedy zájem učitele předat dětem své poznatky nebo zkušenosti nad rámec běžného a vyžadovaného obsahu učiva.

U: „A jinak chrobák. Česky bysme řekli chrobák, který uplácal kuličku, a oni si Egypt'ané představovali, že tadle ta kulička, takhle byl uplácán svět. Že nese, že tento chrobák takhle se pohybuje s námi ve vesmíru a otáčí tou kuličkou a tohoto brouka uctívali. Proto taky je to spojené s těma mumiema a se vším a vy se díváte na horory, jak z toho lezou anebo naopak vidíte, jak ho uctívají anebo prijdete do Afriky, jednoho chrobáka za..., zabijete a oni mají právo vás umučit, což bylo minulé století, ted' už snad ne."

Ž: No, ale možná to zkusím.

U: Ale tento brouk je posvátný v Egyptě. (Dana, 6. ročník, přírodopis)

Předchozí sled otázek učitele a odpovědí žáka byl zaměřený na opakování učiva o broucích, konkrétně chrobákovi, učitelka byla spokojená se znalostmi žáků, a tak se rozhodla vsunout ještě zajímavost propojenou navíc se zájmy žáků, a totiž sledováním hororových filmů, i formou se obrací prrímo na žáky, podporuje tak interakci. I z toho důvodu se objevuje spontánní reakce žáka, ovšem možná s cílem lehké provokace, jaká by mohla zapůsobit na spolužáky. S těmito příklady extenzivních promluv jsem se setkala především v hodinách prrírodních věd a jejich funkcí je pochopitelně objasnění popisovaného jevu ve vztahu k probíranému tématu. Zaznamenala jsem ale i př́́klad z výuky českého jazyka, kdy právě téma hodiny, a totiž média, poskytovalo učiteli přirozenou půdu pro výklad s odkazy mimo základní učivo, které navíc pro tyto žáky bylo opakováním z předchozího ročníku.

U: Samozřejmě, těžko si můžu říct za reklamu, zase omlouvám se, pokud někdo sleduje křest'anské magazíny, ale prostě mě to napadlo na začátku hodiny, uvedu to, jakože to je jeden z pořadů, který má hodně malou sledovanost, eee...

Ž: Nebo třeba Babicovy dobroty na to nikdo...

Ž: Ježiš to je kravina.

U: To by ses divil, jakou to má sledovanost, tak ale když se nad tím, když se nad tím zamyslíte, tak asi nemůžu chtít, asi nemůžu chtít ty samé peníze za reklamu, která bude mezi televizní, televizními novinami a Superstar, kdy v tu dobu na to 
kouká třeba tři miliony lidí, tak za to nemůžou za to chtít tu samou cenu jako třeba nevím ve dvě, ve dvě ráno, kdy opakujou třeba ten křest'anskej magazín, když jsme pořád u něj, aaa dívá se na to ...ve dvě hodiny ráno se na to dívá tak možná deset lidí, tak asi za to nemúžou chtít tu samou cenu. Takže odvíjí se to teda hlavně, hlavně kdy to je a také kde to je. Tak je to docela zajímavý, počítám, kdybyste byli podnikatelé, protože ona ta cena té reklamy je opravdu strašně, strašně rozdílná, tak je to taková otázka přemýšlet o investici, jestliže dám milion korun za reklamu, kterou uvidí tři miliony lidí, nebo jestli radši pưl milionu ušetř́m, to je strašně moc peněz půl milionu, ale v podstatě dám reklamu, kterou uvidí jenom dva tisíce lidí. Ž: To radši to dražší.

U: Myslím si, že většina volí samozřejmě to dražší. Tak tolik reklama, tolik televize eee o rozhlasu v podstatě nemá ani moc cenu hovořit protože všechno co, jsem do ted'ka řekl o televizi, naprosto to samé platí o rozhlasu.

Ž: Tam je úplně to nejhorší to Bauhaus Vám nabízí...

U: Dobře, to jsou reklamy, ale myslím i to rozdělení na komerční a veřejnoprávní platí i u rádií. (Adam, 8. ročník, český jazyk)

Určitou nevýhodu představuje stále v těchto promluvách nadměrnost sdělovaných informací. Ty jsou ale v těchto př́padech důsledkem určité improvizace učitele, jenž reaguje na možnost ukázat žákům, že jeho znalosti a zkušenosti mohou být i zajímavé a odpovídající zájmům třídy, a naznačují uvolnění komunikace směrem k pobouzející se diskuzi.

\subsubsection{2}

\section{Přenos do světa za zdí školy}

Rozšíření obzorů žáků se netýká jen neobvyklých poznatků, ale bývá často zaměřeno na přenos zkušeností ze života. Jedná se však o zkušenosti samotného učitele, odraz nadhledu staršího a propojení s informacemi, které jsou z pohledu učitele důležité pro budoucí život žáků. Nejde zde jen o získání základního vzdělání, ale spojení učiva se světem, kam po vyučování žáci odcházejí. Porozumění žáka je podmíněno propojením jeho studia s vlastními životními zkušenostmi, čímž se u něj vytváří obměněné koncepty poznávaných jevů (Klapko, in Gulová \& Šíp, 2013). Jedním z případů takového propojení je možnost aplikace učiva do praktického života, která je uvedena na začátku této kapitoly, kdy se žáci dozvídají, co dělat v př́ípadě, že se mravenci, které probírají, objeví i doma. Ukázka ilustrovala dopad na motivaci žáků zapojit se spontánně do komunikace ve výuce, která následně 
vyústila v krátkou diskuzi nad učitelčinou otázkou, proč se někteří lidé snaží dostat do těla kyselinu mravenčí. Tady už žáci ale nedokázali přesně odpovědět, a tak učitelka zasáhla do diskuze poučením, kterým uvedla na pravou míru laicky nesprávně vžitou odpověd' „Aby byli zdraví.“.

U: „Většinou jsou to revmatici, klouby je bolí tak, že můžete se hýbnou a ještě to ší.., bolestivé. Tito lidé jsou ochotni lehnout si do mraveniště a nechat se pokousat, protože kyselina mravenčí rozpouští látky v těch kloubech a je to přestane bolet. Takže to ne kvůli zdraví, ale to vyléčení určité nemoci, pomoci od těch té bolesti, zrovna tak ty kopřivy, že jsou, oni se šlehají kopřivama, protože jim to pak rozpouští ty krystalky $v$ těch kloubech.

Ž: Můj děda, on vždycky když šel do lesa, tak si vzdal vždycky klacík, strčil to do mraveniště, nechal to tam hmm nevím jak dlouho, nechal to tam, potom to vytáhl, oklepal z toho ty mravence a lízal to.

U: Proč?

Ž: Tak aby měl kyselinu mravenčí. (Dana, 6. ročník, přírodopis)

Takto zaměřené extenzivní promluvy učitele identifikuji především v přírodovědných předmětech, kde je dostatek témat, která nabízejí také možnost dozvědět se něco, s čím se žáci mohou pochlubit doma rodičům. Na co si možná vzpomenou, až si budou rodiče stěžovat na plíseň na rajčatech na zahrádce.

U: Tak diktuj prosím tě, k čemu se používá síran měd'natý.

Ž: Tak k impregnaci třeba proti hnilobě...

U: Takže je to proti hnilobě, to znamená, že zabírá proti plísním, proti houbovým chorobám, ještě něco?

Ž: A postřikům rostlin proti houbám a dalším škůdcům.

U: Takže v př́padě, že se vyskytují plísně na vašich rostlinách na zahradě, stříká se to síranem měd'natým, víno třeba, velmi často, i když existují už i jiné prostředky, takže jsou to houbové choroby, plísně, postřiky na ně a přidává se do bazénu proti řasám, nevím jestli to tam je, po Fryštácké přehradě vždycky jezdila lod'ka a na ní byl pytel s tímto síranem on jezdil takhle cikcak po té přehradě aby se to rozpouštělo, protože tato nádrž byla silně zařasená nakonec tak, že tam umíraly ryby bez kyslíku, protože ty řasy jim to stihly ukrást. Když máte doma bazény, pokud se tam vyskytují řasy, tak si tam sypete tuto látku, a pak si napište, že je pro člověka alergická, jedovatá. Měla jsem tu kluka, který když jsem ji donesla, tak pčikal, seděl úplně vzadu, Ondru S. znáte? (žáci přitakávají) On okamžitě zaregistroval tu látku, tady ve vzduchu, takže může, jinak u vás jsem, jinak u vás jsem ji 
měla několikrát, je to taková ta modrá sypká látka a nebyl alergický na ni nikdo, ale je to chemikálie, takže se s ní i tak musí dát pozor, protože z ní stř́íká, jakým způsobem, Jirko, budeš postupovat při postřiku vína? (Dana, 8. ročník, chemie)

Učivo o solích v hodině chemie v osmém ročníku je pro část této třídy opakováním, pro zbytek žáků ale novou látkou. Učitelka proto zapojuje některé z žáků, aby zopakovali důležité poznatky z minulé hodiny v rychlém sledu otázek a odpovědí, které uvedly i promluvu, jejíž závěr už ale patří navazující otázce pro žáka. Použití modré skalice do vodních nádrží nebo na zahrádky by přitom mohlo patřit už k informacím, které by někteří žáci mohli sami prezentovat z vlastní zkušenosti. Učitelka přesto volí uzavřenou promluvu, jejíž věrohodnost v případě popisované alergie podpoří jmenováním spolužáka, kterého žáci znají. Tím, že pro část tř́ídy je učivo „jen“ opakováním, nechce se zřejmě učitelka u jednotlivých podtémat déle zastavovat.

\subsection{4}

\section{Nulová reaktivita}

Specifickým případem jsou extenzivní promluvy učitele během samostatné práce žáků, časově se objevují ihned po zadání práce. Promluva, která je určena celé třídě, kdy mluví pouze učitel při kontrole samostatné práce žáků, ale i výroky určené jednotlivcům, slouží jako návod či vysvětlení také zbytku tř́́dy. (Nutno podotknout, že ve většině zkoumaných hodin jsou v těchto př́padech žáci zvyklí komunikovat s učitelem pouze neverbálně, pokud vůbec.)

U: Hmm. Kdo napadá dřevokazné brouky? Napiš si to, já si to projdu. Tady zaprvé nemáš, čím se živí, kde to máme že? No ještě to nemáme napsané, ale už chce vykřrikovat, takže dřevokazní brouci, larvy trouchnivějící dřevo, to je, kde máš, jo tady někde je to psané, trouchnivějící dřevo, jsou to dřevokazní. My jsme si ř́íkali o dřevokazných broucích, výborně, Pét'a ví všecko, protože chodí na olympiádu, kde máme, kdo ho žere? Vzpomínej, opakování, takže je blanokř́dlí neb brouci, když $z$ toho budem psát písemku. Živí se dřevem. Hlavně larvy je to tady, jo trouchnivějící dřevo, blanokř́dlí, listujte blanokř́ílíma, zatím to má jediný Pet'a, nevidím tu jméno to hmyza co nám to, takže druhý David, jo to tu máš čmeláka tady, tady musí být napsané to jméno, třetí, nevím, jak to? Jedničkářky, kašlete na to, musím vás přitlačit tedy přes ně, já ale vás tady ne, vy si začnete... teror tady začne. Škůdce, trouchnivějicí a kdo nám ho, kdo nám ho likviduje? Kdo nám pomáhá ho likvidovat? Vosa ne, vosa nejí dřevokazné brouky, protože ona nemůže tam najít, kdo je žere, 
Sebastiano? Co? No, tady na této stránce je, blanokřídlí, výborně, takže to jsou další, Zuzka má dalšího. Pet'a vám řekne, kdo nám žere. (Dana, 6. ročník, přírodopis)

Tyto promluvy vznikají v reakci na práci žáka, nikoliv na vzájemnou komunikaci, a ačkoliv se učitel v oslovení zaměřuje na konkrétní žáky, nevyvolá tím jinou reakci než neverbální. Domnívám se, že jednou z funkcí tohoto typu extenzivní promluvy je „držet žáky na uzdě“ proto, aby nedošlo k výraznému narušení klidu ve třídě (nebo zhoršení stávajícího šumu). Nesoucí se hlas učitele nad třídou všem žákům předává zprávu, že mají dávat stále pozor a soustředit se. Ticho by zřejmě ve třídě nenastalo. Vhodnější by byly krátké individuální interakce učitele s jednotlivými žáky, ale protože zbytek tř́́dy by nezůstal v klidu, jsou i tyto podoby individuálních sdělení (což naznačuje oslovení jménem, pohled učitele, zabodnutí prstu do žákova sešitu) pronášeny učitelem zvýšeným hlasem a jsou určeny vlastně pro celou tř́́du.

Reaktivita extenzivních promluv učitele je zásadně ovlivněna strukturací celé komunikace ve třídě, schematizací v podobě IRE/IRF struktury, i když př́ípadně s vloženými prvky, jak je popisují kupř́íkladu Scott et al. (2006). Provázanost promluv s předchozí replikou žáka je formálně naplněna, signalizována vyjádřením v úvodu učitelovy promluvy. Samotná extenzivita však poukazuje na to, že učitel se v navazující promluvě opět realizuje jako dominantní mluvčí, jehož promluvy jsou jasně vymezené. Učitel totiž rozhoduje o scénáři reaktivity, a to včetně případu neočekávaného vstupu žáka do komunikace.

Ukazuje se, že potenciál podpořit komunikaci ve tř́íc tím, že následná reakce patř́ žákovi, má především extenzivní promluva, která je nositelem určité bonusové informace ve vztahu k zájmům žáků, možnostem opřít o takovou informaci jejich pozornost pro celé sdělení. Výskyt těchto promluv provází i přepínání registru promluv na méně formální z hlediska jazykových prostředků, ale i tempa či tónu řeči. Uvolnění v řízení komunikace může být pro žáky zachyceným signálem, který přinese jejich spontánní reakci na učitelovu promluvu. Zároveň žáci vnímají i stabilnější projevy učitelova komunikačního stylu.

Záměr nahlédnout pod pokličku promluv učitele v extenzivním žánru přinesl náhled na určité strategie učitele. Expoziční žánr lze přitom vnímat jako zásadní součást výukové komunikace s reflektovanými problémy, které jsou zachyceny především při realizaci vysvětlování jevů a jejich souvislostí. $V$ analyzovaných datech je expoziční žánr často realizován ve formě extenzivních promluv učitele, které však své poselství znesnadňuji informační přesyceností či popíráním významu obsahu promluvy, které si učitel zřejmě ani neuvědomuje. Informační bohatost nad rámec efektivnosti z hlediska percepce promluvy žáky se však týká i dalších žánrů, především instrukčního. 
Ačkoliv se v zachycené výukové komunikaci jedná spíš o okrajové žánry, tedy $\mathrm{s}$ výrazně méně četným výskytem oproti dominantním promluvám expozičního žánru, předkládám v následující kapitole analýzu dalších tří vyskytujících se žánrů. Jejich řazení opět odpovídá tomu, jak jsou v datech zastoupeny. Zatímco výkladu či vysvětlování se odborná literatura věnuje (např. Wittwer \& Renkl, 2008; Geelan, 2013), o práci učitele při sdělování pokynů se mnoho nedozvídáme. Zjištění týkající se instrukčního, evaluačního a apelativního žánru extenzivních promluv by tak mohla být vykročením $\mathrm{k}$ jejich poznání.

\section{1}

\section{Instrukční žánr}

Převážná část extenzivních promluv v získaných datech patří k expozičnímu žánru. Předávání a vysvětlování pojmů k tématu učiva vede učitele častěji k promluvám, které rozsahem a množstvím informací přesahují efektivnější promluvy, do nichž by žáci mohli více vstupovat a měli možnost vstřebat vše (alespoň vše podstatné), co jim učitel sděluje. Druhou nejvíce zastoupenou žánrovou podobou extenzivních promluv jsou instrukce učitele. Jejich menší výskyt oproti expozičnímu žánru je ovšem důvodem pro identifikaci pouze dvou subžánrů, jak dokládá následující tabulka č. 3. 
Tab. 3 Přehled žánrů extenzivních promluv učitele patřících k instrukčnímu žánru

\begin{tabular}{|c|c|c|c|}
\hline SUBŽÁNR & $\begin{array}{c}\text { HLAVNí } \\
\text { KOMUNIKAČNí Cíl }\end{array}$ & $\begin{array}{c}\text { DOMINANTNí } \\
\text { FUNKCE }\end{array}$ & $\begin{array}{c}\text { PRVKY VNITŘNí } \\
\text { STRUKTURY }\end{array}$ \\
\hline instrukce úkolová & $\begin{array}{c}\text { Předat návod pro spo- } \\
\text { lečnou činnost třídy } \\
\text { na zadaném úkolu }\end{array}$ & návodná & $\begin{array}{c}\text { Důraz na pojmenování } \\
\text { učební činnosti a oče- } \\
\text { kávaný výstup úkolu }\end{array}$ \\
\hline instrukce okolnostní & $\begin{array}{c}\text { Předat návod pro } \\
\text { zajištění organizace } \\
\text { při činnosti třídy } \\
\text { na zadaném úkolu }\end{array}$ & organizační & $\begin{array}{c}\text { Dưraz na vymezení } \\
\text { pravidel pro organiza- } \\
\text { ci činnosti }\end{array}$ \\
\hline
\end{tabular}

U instrukce, pokynu, což je běžná forma zadání požadavku ze strany učitele na žáka nebo celou třídu, nemusíme na rozdíl od předchozího expozičního žánru očekávat, že by se vyskytoval v podobě extenzivní promluvy. Proč se tedy instrukce ve výukové komunikaci v našich datech objevuje v této podobě?

Pozitivním případem rozšíření instrukce učitelem je nadstavba (myšleno oproti většině našich nálezů, ale přesto ji nacházíme), která kromě pouhého sdělení pokynu žákům usiluje o předání cíle jejich následné činnosti. Tu učitel může uvádět explicitně („,...Mně jde o to abys...abych viděl, jak premýšlíte, jestli si to dáte dohromady, ale jak jsem ř́kal, ty obrázky vůbec na sebe nijak nenavazují, a asi uznáte, že to s literaturou nemá nic společného ty jednotlivé obrázky." (...). Zachycena je také ve formulaci vlastního přání učitele (,...Eště jednou říkám, že jsou to úryvky z té kralické Bible, tak ted' máte chviličku času na to, abyste si to sami přečetli a potom abyste nám o tom vyprávěli, co jste se dozvěděli, jsou to př́běhy, o kterých jsme si nic neříkali, schválnějsem neříkal stvoření světa, nebo schválně jsem nekopíroval stvoření světa, protože to znáte všichni, ale třeba se dozvíte něco nového.").

Kromě cíle (či přání, jaké by práce žáků mohla nést ovoce) může učitel během instrukce žáky přímo navádět $\mathrm{k}$ tomu, jaký výsledek by jejich práce vlastně měla mít. Jedná se však o mírnou manipulaci učitele s žákovskými odpověd’mi, i když může sloužit i pro získání zájmu žáků o zadaný úkol.

U: Tak, ale když už jsem tady u těch článků, které jsem vám chtěl rozdat, to už ted' nestihnem, tak poslouchejte, přečtu vám jeden...jeden článek. Schválně, co se vám na tom bude zdát divného, holky. (...) Tak poslouchejte. Nebo nejdř́v se zeptám. Co byste očekávali, že v tom článku bude? (Adam, 8. ročník, český jazyk)

Učitel Adam se v závěru vyučovací hodiny nejspíše snažil zaujmout žákyně, u nichž předpokládal, že analýza článkủ v bulvárních novinách by pro ně v 8. ročníku 
mohla být poutavá. Učitelé však v instrukcích jinde nastavují jasné mantinely plnění pokynu, který jim předávají. Důsledkem je pak pasivita žáků, kteří nemají důvod uvažovat nad instrukcí a jejím řešením nad rámec vymezeného prostoru. Prostorové omezení v kontextu instrukčních promluv se pak týká i organizační formy zvolené učitelem, jež také ovlivňují možnosti žáků zapojit se do probíhající komunikace aktivněji.

Analyzované instrukce se dotýkají vymezení pokynů pro individuální nebo hromadnou práci žáků. Ačkoliv se jedná často o hodiny, kde učitel s tř́dou opakuje dřive probrané učivo, hromadná výuka je pro ně běžnou formou. Hodiny se snaží zpestřovat spíše individuálními úkoly s využitím pracovních listů nebo materiálů promítaných na dataprojektoru. Když dochází v jedné ze zaznamenaných hodin $\mathrm{k}$ tomu, že učitelka avizuje prostor pro práci ve dvojicích, trvá ještě př́liš dlouho, než se k ní přes společné činnosti dostanou. Změnu formy tak nakonec limituje blížící se konec vyučovací hodiny.

U: „....tak a ted' už bych vám dala tedy prostor pro práci ve dvojicích nebo trojících, tam máme trojičku a skrývačku, děcka, víte co to je skrývačka? Ve větě skládáte z konců a začátků slov nějaké slovo, máte tam tedy nápovědu, že je tam řeka a město, čili podtrhněte, jo nebo oddělte nějak ta slova. Šotek znamená, že tam došlo k nějaké chybě, máte opravit chybné názvy a zkuste najít nějakou logiku v tom. Eee další je přrı̌azovačka, pokud byste tam těch čar měli hodně, klidně si pište vedle ty dvojice, vždycky číslo a k tomu písmenko. Přesmyčky znamená, že máte všechna písmena slova a máte je přeházet, aby vám vyšel správný název no a poslední je jenom taková testová otázečka, máte napsat, co jsou to řopíky a pokud nevíte, radši nepište nic. Využijte u toho atlas." (Adéla, 8. ročník, zeměpis)

Učitelka už s vědomím časového limitu rychle vyjmenovává a vysvětluje všechny části. S aktivním přístupem žáků (kdo by nedokázal odvodit sám, co by mohla být skrývačka?) se nepočítá. Naopak. Učitelka žákům dokonce sděluje, že iniciativa v jedné z odpovědí není vítána a než se pokusit o odpověd', byt' ne správnou, raději „nepište nic“.

Omezení odpovědí žáků je také jedním z vyskytujících se mantinelů komunikovaných učitelem ještě předtím, než se žáci vůbec mohou dostat ke slovu. „Tak já jsem ř́lkala, že nechci žádná čísla, rozlohu, počty obyvatel, ale...", ř́íká jindy opět učitelka Adéla. Nejedná se však o reakci na neporozumění instrukcím ze strany žáků. Negace je do instrukce vkládána již na začátku. 


\subsection{1 \\ Instrukční vata}

Pokud v analyzovaných hodinách dojde k rozšśření instrukce do podoby extenzivní promluvy, zásadním vlivem je postupné nabalování informací v promluvě, zmatečnost výpovědí. Učitelé pak stejně jako v následující ukázce mají tendenci vložit do instrukce vše, na co by se jinak žáci mohli zeptat, pokud by učitel nad takovou možností uvažoval. Případně pokud by byl ochotný poskytnout vzácný čas vyučovací hodiny i zapojení žáků do společné elaborace činnosti žáků. Učitel od jádra instrukce odskakuje $\mathrm{k}$ dalším výpovědím. Ztrácí se tak nejen pozornost žáků, ale snaha učitele předat všechny související informace mívá také paradoxní dopad v tom, že žáci nakonec potřebují zopakovat ještě jednou stěžejní část, která se v záplavě informací ztrácí.

U: „Já vám tady dám každému, mám tady dva texty, tak každému dám od některý, jsou to právě ukázky z Bible kralické a vaším úkolem, Patriku, vaším úkolem je prečíst si tu ukázku a za chviličku, protože máte každý jinou nebo máte dva druhy těch ukázek, tak jedna, poslouchejte mě, at'víte co máte dělat ... tak jedna skupina bude té druhé vyprávět o čem v podstatě jste četli, je tam stavění věže, jedna skupina má stavění věže, druhá skupina má Moudrosti Šalamounovy, znovu ř́kám, Patriku, eště jednou ř́íkám, že jsou to úryvky z té kralické Bible, tak ted' máte chviličku času na to, abyste si to sami prečetli a potom abyste nám o tom vyprávěli, co jste se dozvěděli, jsou to príběhy, o kterých jsme si nic neř́kali, schválně jsem neř́kal stvoření světa, nebo schválně jsem nekopíroval stvoření světa, protože to znáte všichni, ale třeba se dozvíte něco nového. Potichu, máme na to málo času, tak bud'te potichu, at' nerušíte ostatní...Já vím, že jsem vám na to nechal hodně málo času, ale ono nám bude zvonit." (Adam, 7. ročník, český jazyk)

Není neobvyklé, že učitel musí upozornit výslovně žáky na význam samotného sdělení instrukce ve výroku typu „Poslouchejte mě, at’ víte, co máte dělat.“. Jádro instrukce učitele Adama se týká práce se dvěma odlišnými texty, přičemž naznačuje využití strategie skupinové práce, ale prozatím s nejasnými pravidly. Není nutné představit detailně další fáze zadané činnosti v jediné promluvě. Celá instrukce je však obalena mnoha dílčími informacemi, které by učitel mohl předávat postupně. Žáci se dozvídají původ a důvod volby textu, ovšem učitel jej stihne ještě zlehčit formulováním pochybnosti o nových informacích, které jim text může přinést. Napomíná žáka, jenž nevěnuje učiteli pozornost, využívá pravděpodobně hlasový projev k tomu, aby koncentroval pozornost žáků. Konkretizuje téma textu a průběžně se do vyjadřování zaplétá. Během extenzivní promluvy učitel verbalizuje 
stresový faktor blížícího se konce vyučovací hodiny. Domnívám se přitom, že pokud žáci v informační záplavě zachytí sdělení, že na plnění úkolu zbývá jen „hodně málo času“, mohou pochybovat o jeho smysluplnosti a mají v 7. ročníku již zkušenost s tím, že za takových podmínek nebude učitel mít čas ani na případné hlubší negativní hodnocení, které by pro ně bylo nepř́íjemné.

Postupné nabalování sdělovaných informací, případně i přepínání mezi žánry v rámci extenzivní promluvy, působí zmatečně. Nejasnost vyjádření komplikuje možnost porozumění, jedná se o případy, kdy učitel jednoduše řečeno mluví déle, než by bylo pro žáky přínosné.

U: Ještě se vrátíme $k$ mravencům, tys mě přerušil Pet'o, chtěla jsem vám ještě ríct něco o mravencích, protože o těch se dá povídat dlouho, ale my půjdem $k$ tomu, co jste si napsali, abychom se dostali k broukům. Vaši úkolem je pod tu krásnou berušku, co všichni máte, si napsat tři, nebo pět básniček, pohádek, pověstí o broucích, kde vystupuje brouk. Pište si tam, piš, pište mi to, já chci, aby každý z vás mně řekl...já se podívám. Takže ted' je úkol pro všecky každý bude mít jiné tři až pět pověstí, pohádek, říkanek, kde vystupuje brouk jako jedna z hlavních postav. Jo tři až pět byste mohli dát, zvláště když vidíte tu berušku, já vám napovím, co děláte s beruškou? A už to píšu, máte jí takhle na prstě a ptáte se jí na něco jo? To je první, no máte tam slunéčko sedmitečné, at' neříkám beruška. Jste hudebníci, tak byste si měli..., spoustu večerníčků bylo. A máte, máte, všichni sami, každý zkuste sám si vzpomenout, pohádky, ř́kanky, pověsti. Nebo kde vystupuje brouk jako jedna z postav, takže nemusí to být název. (...) (Dana, 6. ročník, přírodopis)

Dochází zde k tomu, že učitelka sice žákům sděluje, že se přesunují k tématu „brouci“, ale její vyjádření zaniká v nejasné instrukci, která bezprostředně navazuje na úvodní větu. Instrukce učitelky vykazuje skutečně nadměrné množství informací, o nichž zřejmě očekává, že je žáci zvládnou zachytit i zpracovat. Domnívám se však, že zároveň s tím, že žáci již začínají na úkolu pracovat, pro ně není možné se v promluvě adekvátně zorientovat. Žáci se proto dotazují na to, co bylo řečeno, úkol navíc stále plní, jakoby zadáním byli původně probíraní mravenci, po několika dalších replikách učitelka při kontrole sešitů žáků musí znovu důrazně sdělit třídě: „Přeskočíme k broukům.“ 


\subsection{2}

\section{Jazyk instrukce}

V promluvách instrukčního žánru v získaných datech bohužel dost silně rezonuje ironické vyjadřování některých učitelů. Ironie v instrukci (stejně jako v celkovém komunikačním projevu učitelů) ukazuje na dominanci učitele, která přerůstá snahu o vymezení rolí v řízení komunikace ve třídě. Soustavná ironie, kterou záznamy naznačují, stěží pomůže žákům v motivaci pro řešení úkolů.

U: Tak, no a my právě ve střední Evropě najdeme nějaká kerná pohoří, takže ted' už pojd'me pracovat s atlasem a doporučuju teda vzít si už atlas, střední, mapu střední Evropy v atlase strana, stále mě překvapuje, že většina z vás má nalistovanou politickou mapu, tam teda opravdu moc pohoří nenajdete. 34, 35, 34, 35, kde máte Evropu a ted' už zkusme charakterizovat povrch, sami. Vyhledám, bereme jenom střední Evropu, už víme, které státy probíráme. Dokázali byste jednou větou, ten povrch charakterizovat? Ád’o zkus. (Adéla, 7. ročník, zeměpis)

Pokud si takto při četbě transkriptu dat do textové podoby můžeme domyslet, jakým tónem učitelka ironickou poznámku pronáší, lze si ideálně představit i přátelský hlas, případně náznak úsměvu. Pak by žáci v její třídě mohli toto „popíchnutí“ vnímat jako snahu o jejich pozornost. Prostřednictvím videozáznamu však víme, že ironii používá učitelka Adéla jako výraz nelibosti, někdy až despektu, čemuž odpovídá její paralingvistická i extralingvistická komunikace. Učitelka zachovává tradiční komunikační strukturu IRF, avšak žáci jsou zavaleni extenzivními promluvami, které nahrazují situace $\mathrm{v}$ komunikaci, kde bychom předpokládali častěji učitelem položenou otázku žákům. Paradoxně vytýká žákům, že při vlastních výstupech hovoří jen heslovitě, avšak sama se dále ve výukovém dialogu spokojí s jednoslovnou či jen neverbální naznačenou odpovědí žáků, kteří tak akceptují tento způsob jejich vzájemné komunikace a nejsou nijak motivováni k rozvitějším odpovědím na učitelčiny otázky. Objevuje se nepřítomnost zájmu učitelky o pohled žáka, zároveň jsou promluvy učitelky ty pické častým vkládáním slovíčka „jo“, kdy vytváŕí dojem interakce, udržení spojení se žáky během extenzivní promluvy, avšak jejich reakci vlastně ani nepředpokládá. Zároveň se v promluvách dopouští komunikačních přešlapů, jaké jsem ilustrovala už v kap. 8.2.3 a kterými porušuje etické principy, jež by profesionál překračovat neměl.

Vyjadřovaná verbální dominance ve formě despektu učitele se může nenápadně skrývat $v$ jediné informaci z celé promluvy. Další příklad instrukce z výuky zeměpisu učitelky Adély ukazuje opětovné zasazení takového komentáře mezi ostatní informace. Text zároveň ilustruje, jak v promluvě, která na první pohled nemá tak 
značný rozsah, nacházíme nadbytečné množství informačních jednotek, jež musí žáci přijmout a zpracovat. Jedná se o pokyny k učebním pomůckám, sdělení podstaty následné činnosti (lokalizace střední Evropy), upřesnění činnosti, uvedení odlišností ve druzích map, jejich pojmenování a barevné rozdíly, další upřesnění úkolu (práce s vysvětlivkami). A zdá se, že učitelka reaguje na neverbální komunikaci žáků, případně reflektuje, že informací zaznělo příliš mnoho, když v závěru instrukce dodává „udržme tu informaci trochu.“ Zodpovědnost zůstává tedy na žácích.

U: No, a abychom ted' si tu střední Evropu úplně přesně lokalizovali, podívali se, kde leží tak nechte atlasy otevřené a otevřete si učebnici. Otevřete si učebnici, tak na straně 66. A tady máme barevně vyznačeny státy střední Evropy, ted' si přesně řekneme, které tam leží. Strana 66, kde je mapka, není obecně zeměpisná, barvy jsou tam úplně jiné, než které se používají na mapách, ale máme tam znázorněny státy střední Evropy, takže si vyjmenovat podle vysvětlivek, obzvlášt'některýnázev někteří uslyší poprvé v životě. 66, udržme tu informaci trochu. Tak pojd'me začít, Pepo. (Adéla, 7. ročník, zeměpis)

V jazyce promluv instrukčního žánru nacházíme příklady rozdělení rolí ve třídě na pozicích ve vztahu k řízení práce. Učitel tak pojmenovává sebe jako zadavatele. Potvrzuje svou dominantní roli a žáci jsou prostě příjemci instrukce.

U: Mưj úkol pro vás je eee jenom rozdělte se v té skupince ještě na dvě skupiny, jedna tak skupina, třeba Viktor s Honzou si vezmou Aha, když už to má Honza v ruce, kluci si vezmou lidovky, tady holky si vezmou Blesk, Ruda s Míšou si vezmou, co máte? Mladou frontu a jenom to prolistujte, zatím si nic nečtěte, Rudo, zatím si nic nečtěte, jenom to prolistujte, jenom se koukejte, co tam, co tam uvidíte. (Adam, český jazyk, 8. ročník)

Jazyk instrukce může vyvolávat zdání, že žáci skutečně plní pokyny jen pro učitele samotného, nikoliv pro vlastní rozvoj poznatků. Takto učitelka Dana v hodině chemie diktuje zadání žákům:

U: Vyrob mně chlorid dr..., vyrobte mi sto gramů chloridu draselného, mohli jsme i dusičnanu, chloridu draselného bude stačit, jo? Vyrobte mi sto gramů chloridu draselného, rovnice bude neutralizace přesto, že se to dá i jiným způsobem, chloridem draselným jsme začli, chloridem draselným skončíme. Vyrobte mi sto gramů chloridu draselného, rovnice bude neutralizace, tady vám to zadám. (...) Draselný, takže víte základní látky, že tam vzniká voda, už musíte umět. A kdo to bude mít, 
se může sbalit, já mu to zkontroluju. (prochází třídou a kontroluje sešity) Pořád jsou to jednoduché, ty se nedorovnávají tyto rovnice. Neposloucháš, ničemo, říkali jsme, že bude há cé el reagovat s hydroxidem draselným. Musí tam vzniknout co? Hydroxid, kyselina... dole jo? A počítám ...já chci vyrobené jenom sto gramů, kde máš odpověd'? Vyrobte mi sto gramů chloridu draselného a kolik potřebuju hydroxidu draselného. (Dana, 8. ročník, chemie)

Kromě úkolu jako zdánlivé zakázky od učitele směrem k žákům, a to včetně zdůraznění kontrolní funkce učitele, je do instrukce vkládán už i komentář pro žáky, kteří se rychle pustili do práce. Motivovala je pravděpodobně vidina slíbeného odchodu ze třídy, což zpo̊sobilo chybné výsledky jejich individuální práce. Učitelka je komentuje u jednoho žáka tím, že ho označí za ničemu, přičemž tento způsob vyjadřování je pro ni typický, vzápětí se rozhoduje podstatnou část instrukce znovu zopakovat. Blížící se konec vyučovací hodiny (zároveň i celého dne, protože se jednalo o poslední hodinu pro třídu i učitele) ovlivnil opět možnosti prolomit extenzivní promluvu vstupem žáků. Učitelka jen konstatuje, že mimo zadanou sloučeninu by bylo možné využít i jinou, stejně tak sama vybírá jeden ze způsobů řešení. Lze si jen domýšlet, kolik žáků by dokázalo rozhodnout o dalších variantách, vysvětlit svou volbu, opustit cestu pohodlné přímé instrukce učitele.

Naopak odklon od verbální dominance v jiných zachycených případech, jaký by mohl lépe působit na motivaci žáků, a to včetně motivace pouštět se do diskuze nad obsahem instrukce předávané učitelem, se vyskytuje ve dvou formách instrukce. Jednou strategií je přepnutí v jazyce učitele na kód společného, sdíleného úkolu („naším úkolem bude pořešit tady příklad“), druhou pak dokonce posun v roli učitele, který žáky žádá o pomoc. „Pojd'me tedy zkusit zjistit, kolik korun dostane to město za pronájem. Porad', porad'te, jak to vyřešíme.". Namísto omezujících mantinelů se dostává žákům podpory dokonce i v tom, že mají možnost volby konkrétního řešení.

$U:$ Nebo si prevedeme hned na decimetry a budeme počítat $v$ decimetrech, $v$ decimetrech čtverečných. Takže nechám na vás, jak se rozhodnete, v každém případě pojd'me spočítat obsah toho pláště, jo? Nechám na vás, jak se rozhodnete, v jakých jednotkách, můžete počítat vy stejně v sešitě, a my tady na tabuli, nebo můžete zkusit své výpočty. Tak píšeme sedmdesát tři lomeno šest a nejdřív chci, abyste mi tady někdo přišel načrtnout, jak vypadá rozvinutý plášt'. Tak pojd', Dane. Klidně si učebnici vem, protože já po tobě budu chtít, abys nám připsal taky rozměry. 
Nakonec ale učitelka zklamaně konstatuje, že:

U: (...) Tak děcka prosím vás přemýšlejte nad tím, co počítáte a proč. Takže, vyšel vám stejný obsah? Počítal někdo v decimetrech od začátku? Nikdo, opisujem, co je na tabuli, dobře. (Adéla, matematika, 7. ročník)

Pouze občasné přepnutí učitele mimo vyjeté koleje stereotypní komunikace s tendencí vše vymezovat a řídit, nemůže být totiž dostatečným signálem pro žáky, aby na změnu strategie přistoupili. Naučená pasivita zřejmě přetrvá přinejmenším v komunikaci s daným učitelem ve školní třídě. Instrukce přitom vůbec nemusí být sdělována pouze učitelem. Žáci sami se však musí učit reagovat na změnu stereotypu, pokud se jiný učitel rozhodne nastavené pozice proměňovat a vyžaduje po žácích vlastní návrhy, postupy, společná řešení.

\section{2}

\section{Evaluační žánr}

Evaluační aspekt extenzivních promluv byl předmětem zájmu ve vymezeném evaluačním žánru. Evaluaci nacházíme v literatuře jako jednu ze tří složek struktury IRE uzavírající zhodnocení repliky žáka učitelem, a to teprve v okamžiku, kdy dostane požadovanou správnou odpověd' (Mehan, 1979 in Šed'ová et al., 2012). Jako širší rámec možných reakcí učitele v dané struktuře pak existuje varianta IRF, kde „F“ představuje „feedback“ neboli zpětnou vazbu. I předkládané vymezení evaluačních žánrů v této kapitole překračuje užší pojetí, v němž by bylo obsaženo pouze zhodnocení repliky žáka. V extenzivní promluvě učitele obvykle totiž rezonuje hodnocení žákova výkonu ve spojení s dalším vysvětlováním či snahou o souhrn podstatných aspektů učiva, kterého se evaluace týká. Zůstáváme tak u pojmu evaluace, který je také vhodnější pro označení daných žánrů, stejně jako další autoři. Nystrand (1997 in Šed'ová et al., 2012, s. 170) ve své práci uvádí mezi kritérii dialogického vyučování tzv. evaluaci vyššího řádu, která přináší žákům zpětnou vazbu s komentářem, doplněním a rozpracováním. Tomuto kritérii odpovídají některé evaluační extenzivní promluvy v získaných datech, ovšem těchto př́ípadů není mnoho. K rozšíření promluv učitele dochází totiž často proto, že se učitel snaží do promluvy vtěsnat vše, co by mohlo být pro žáky v dalším učení důležité. Promluva pak neslouží jako potřebný dílek stavěného lešení v procesu porozumění. 
U: „Prosím vás, ještě jednou říkám, že když, eee, řeknu, že ve vypravování v tomhletom okamžiku by tam měly být citoslovce, tak že tam vyloženě musí být. Jo, tady se to třeba nehodilo, tady nikdo neprásknul dveřmi, takže tam zase neviděl bych to jako velkou chybu, ale chápu, že jsme si říkali, že by tam měly být citoslovce... eee, mně se tam spíš nelíbila jedna věc, můžu si to pučit prosím tě, Honzo, já jsem si to nepsal úplně všechno... a to je stálé opakování jednoho slovíčka, kterého si, kterého se těžko zbavujeme, protože v podstatě $v$ tom minulém čase v první osobě se používá skoro pořád." (Adam, 6. ročník, český jazyk)

V analyzovaných datech se vyskytly dva subžánry přinášející hodnotící informace žákům. Jak ukazuje následující tabulka č. 4, odlišují se tím, zda se hodnocení zaměřuje na aktuální činnost a výkon žáka, nebo se vztahuje k celkovému posouzení zvládnutí určité oblasti učiva. Zároveň se pouze ve druhém případě vyskytovalo hodnocení v čisté žánrové podobě, tedy bez prolínání s jazykovými prvky, jaké nacházíme ve vysvětlení patřícímu k expozičnímu žánru.

Tab. 4 Přehled žánrů extenzivních promluv učitele patřících k evaluačnímu žánru

\begin{tabular}{|c|c|c|c|}
\hline SUBŽÁNR & $\begin{array}{c}\text { HLAVNÍ } \\
\text { KOMUNIKAČNí CÍL }\end{array}$ & $\begin{array}{c}\text { DOMINANTNÍ } \\
\text { FUNKCE }\end{array}$ & $\begin{array}{c}\text { PRVKY VNIT ŘNÍ } \\
\text { STRUKTURY }\end{array}$ \\
\hline hodnocení vysvětlovací & $\begin{array}{c}\text { coudit činnosti žáka s využitím } \\
\text { doplňujícího objasnění } \\
\text { jevu }\end{array}$ & evaluační & $\begin{array}{c}\text { Důraz na hodnotící } \\
\text { prostředky s oporou } \\
\text { o sdělení doplňujících } \\
\text { informací k tématu }\end{array}$ \\
\hline hodnocení souhrnné & $\begin{array}{c}\text { posoudit celkové } \\
\text { kvality/úrovně úseku } \\
\text { vyučovací hodiny }\end{array}$ & evaluační & $\begin{array}{c}\text { Důraz na shrnující } \\
\text { hodnotící informace } \\
\text { a jejich využití }\end{array}$ \\
\hline
\end{tabular}

Nejvíce zastoupeným případem extenzivní evaluační promluvy v mých datech je využití evaluace k uzavření probíraného tématu. Hodnocení slouží žákům jako souhrn probíraného učiva po uzavření předchozí výměny replik mezi nimi a učitelem. Pro žáky by to mohl být signál, že pokud ještě chtějí k tématu něco podotknout, měli by toho využít. Dochází však k tomu, že akceptují učitelovo uzavření a vyčkávají, co se bude dít dále. Obsáhlá evaluační promluva učitele Adama v následující ukázce přináší souhrnné zhodnocení s netradičně vyjádřenou pochvalou v podobě poděkování a humorné nadsázky srovnávající zaujetí žáků.

U: „Tak, jestli už nikdo nemá vyloženě chut' si to tady přečíst před ostatními, tak bych to zakončil tak, že se vůbec neobávám...a vůbec se... nebojím i toho, až budete 
psát vypravování vyloženě na známky...což bude...brzy...bude to bud' za 14 dní nebo za tři týdny i podle toho, jak se domluvím s ostatními...ehm.., budeme psát slohovku čtvrtletní, bude to na vypravování, měl jsem z toho strach, protože jste $v$ šesté třídě, nečekal jsem od toho moc, ale aspoň ti, co dneska mluvili, tak nasadili vysokou lat'ku, eee...viobec vůbec žádné velké výhrady k tomu nemám, něco... jsme možná opravili, ale rozhodně to nebylo nic, co by co by bylo tak strašně moc důležité. Děkuju teda těm, kteři si nebáli tu vystoupit. Hlavně taky děkuju těm, eee, kteří poslouchali a hledali, hledali v tom chyby nebo naopak výhody nebo přednosti... a ještě bych chtěl říct jednu věc... a to je to, že, eee, v podstatě kolik? Třicet minut? Třicet minut jsme to tady četli a jestli jste si všimli, tak možná tady byl jeden člověk, možná dva, které to až tolik pak už moc nezajímalo, což na to, že jsme tady poslouchali třicet minut dokolečka pořád na to samé téma vypravování, je docela složité to vyprávět tak, aby ten druhý u toho neusnul a viděli jste, že i co normálně, nebudu ukazovat, Evi, ti, co normálně nevydrží dávat pozor ani pět minut, tak prostě jste dokázali, abych teda, Evi, nevydržíš ani pět minut, ted' celou půlhodinu, takže možná vás to zaujalo to učení, mně se většinou nedaří zaujmout tady půl hodiny." (Adam, 6. ročník, český jazyk)

Reakce tř́idy zůstává neurčitě jen v neverbální rovině. Pochvíli ticha tedy iniciativu v komunikaci přebírá opět učitel Adam a přechází na další plánované téma výuky.

Případem specifické extenzivní promluvy jsou složené evaluační bloky, kterými učitelé hodnotili výkon jednotlivých žáků v předchozí individuální práci. Učitel Martin se takto obrací jmenovitě na dané žáky, jejich reakce je však neverbální, nebo zcela skrytá oku pozorovatele. Komunikace učitele tak zůstává jednostranná a má formu souvislé promluvy.

Máme tři, co to nepsali minule, co to psali minule tak, tak teda psali... u všech třech je vidět, že něco pro to udělali, aby ta písemka dopadla dobře. Nejvíc proto udělala Katka, to je její tradicí. (jde ke Katce) Katko, dobrý, dá se říct perfektní, já jsem ti tam nenapsal hvězdičku, ježíšmarja. (Jde ke Katce, prohledává pouzdro) Půjčím si jo? Tak, je tam. Jo. Napíšeš si to do žákajdy. Maríno je vidět, že ses začala učit (jde směrem $k$ učitelskému stolu, sedne si na stůl), je to poznat. Ještě ty otazníky přesun̆, do toho mluveného projevu, a jestli, něco nevíš, tak se zeptej, a potom si myslím, že to nebude tak špatný, dva až tři. (sedí na učitelském stole) Jo, Ondro, ty máš dobrovolné úkoly mít možnost udělat. Tak, Filip, tak kde tě mám tentokrát. Filipe dobrý až na ten prevod, ale dobrý je za tři, a tak za tři to není. (Jde k Filipovi) Ale je to za dva, takže chvalitebný, a ještě ten převod, ještě jsem před tou hodinou vysvětloval, že chci u toho prevodu aspoň ten postup, abych tam mohl něco 
hodnotit. Takhles tam napsal akorát číslo. Je to protože vůbec nevěděls nebo, nebo, nebo, nebo proč tam je jenom to číslo? (nečeká na odpověd' žáka) Jako to nevím. My jsme to tady dělali jeden převod na tabuli, vyšel na pět minut, nemůžeme víc psát př́kladů nebo tak, jo.

Hodnocení jednoho ze žáků doplňuje učitel Martin doporučením, které odkazuje na volnou možnost dotazování v př́ípadě, že něčemu nerozumí. Nabídka zůstává jen formálním sdělením, pokud učitel v hodinách nejde př́íladem. Učitel Martin si pro naplnění úvazku výuky vybral záměrně 6 . ročníky, protože se ve škole poprvé setkávají s fyzikou, a tak chce žáky pozitivně motivovat, aby se „nebáli něčeho, o čem ještě neví, o čem to vlastně je a slyší jenom od rodičů, jak je fyzika strašně těžká a že to nezvládnou.". Kromě vlivu na motivaci pro předmět by pro žáky mohla být stěžejní také komunikační strategie učitele. Pokud by skutečně mohli volně pokládat otázky (a nejen k úsekům učiva, kterým zrovna nerozumí) a tato strategie se jim osvědčila podporou učitele, mělo by to pro ně zásadní význam.

Evaluace vyvolaná situací probíhající aktuálně ve třídě, může být namířena i na konkrétního žáka, což se přihodilo ve výuce přírodopisu. Uvádějící výrok učitelky Dany možná nepřekvapí pozorovatele jejího komunikačního stylu, daného žáka ale údernost prohlášení naprosto vyděsila. Učitelka tak použije jeho nesprávně vypracovaný úkol jako odstrašující příklad pro celou třídu, která se nakonec v promluvě dozvídá, proč učitelka považuje chybu za tak závažnou, že ji bez přemýšlení ohodnotí nejen verbálně, ale také známkou nejhoršího stupně.

U: Takže Michal to má dneska za pět.

Ž1: Jak to, jak to že, cože?

U: Co udělal za chybu? (zvedá a ukazuje sešit žáka Michala)

Ž1: Ježišmarja.

U: Co udělal za chybu?

Ž2: Má krátké tykadla.

Ž3: Má je ze zadku.

U: Péta na to první došel, ale já jsem chtěla, aby přemýšlela celá tř́da, jestliže po měsíčním kurzu, co měsíčním, dvouměsíčním kurzu o hmyzu si schopen zakreslit tykadla, které jdou ze zadečku, tak je to, Míšo, opravdu vážná chyba a není to k smíchu. Jo, to musím oznámkovat, protože my dva měsíce říkáme, že tykadla jdou z části, které rríkáme hlava. (Dana, prírodopis, 6. ročník)

Ačkoliv datový materiál $v$ tomto výzkumu zachycuje výuku v různých časových obdobích školního roku, evaluační žánr ve formě extenzivní promluvy je 
zastoupen spíše okrajově. Učitelé věnují prostor evaluaci práce žáků ve zmíněné podobě struktury IRE, kdy evaluace je obvykle stručným vyjádřením k předchozí odpovědi žáka, nedochází zde ale k rozšíření učitelových promluv.

\section{3}

\section{Apelativní žánr}

Ještě méně než předchozí evaluační žánr je v datech zastoupen žánr, jehož pojmenováním se rovněž snažím vystihnout podstatu toho, proč se ve výuce objevuje, jaká je jeho společná funkce. Jedná se o promluvy, které kromě sdělované informace mají ještě i apelovou funkci (Světlá, 2003). Nastávají zde situace, kdy se extenzivní řeč učitele nezaměřuje už na obsah výuky. Učitel promlouvá jak ke zvolenému žákovi, tak i k celé třídě, aby bud' žákům sdělil organizační záležitosti týkající se chodu třídy, nebo upozornil na určité problémy s chováním, které aktuálně nastaly. Cílem je ovlivnit chování jedince či skupiny a jejich postoj ke světu prostřednictvím různých výrazových prostředků. Prvky výchovného apelu přitom nacházím i v promluvách jiných žánrů. Jedná se však o výchovu k zodpovědnosti ve vztahu k učení, nikoliv vůči chování či povinnostem žáků navštěvujících školu jako instituci.

Tab. 5 Přehled žánrů extenzivních promluv učitele patřících $k$ apelativnímu žánru

\begin{tabular}{|c|c|c|c|}
\hline \multicolumn{1}{|c|}{ SUBŽÁNR } & $\begin{array}{c}\text { HLAVNí } \\
\text { KOMUNIKAČNí Cíl }\end{array}$ & $\begin{array}{c}\text { DOMINANTNí } \\
\text { FUNKCE }\end{array}$ & $\begin{array}{c}\text { PRVKY VNITŘNí } \\
\text { STRUKTURY }\end{array}$ \\
\hline výchovné upozornění & $\begin{array}{c}\text { Regulovat nevhodné } \\
\text { chování žáka/tř́ídy }\end{array}$ & regulační & $\begin{array}{c}\text { Důraz na výchovné } \\
\text { prostředky v řeči }\end{array}$ \\
\hline tř́dnické sdělení & $\begin{array}{c}\text { Předat informaci } \\
\text { k organizaci třídy }\end{array}$ & organizační & $\begin{array}{c}\text { Dủraz na organizační, } \\
\text { sdílené informace pro } \\
\text { chod třídy }\end{array}$ \\
\hline
\end{tabular}

Ačkoliv se podle literatury učitelé musí ve výuce ve velké míře věnovat kázeňským záležitostem (Cangelosi, 2006; Bendl, 2011 aj.), menší zastoupení žánru s výchovnou funkcí je ve zkoumaných vyučovacích hodinách způsobeno zřejmě hlavně proto, že si učitelé uvědomovali přítomnost videokamery ve třídě. Nepozornost a nekázeň $v$ hodinách řešili obvykle bud' stručným napomenutím, komentářem (často s nevhodnou formou) nebo je ignorovali. Přesto nastaly ve třídách situace, na které učitelka navzdory pořizování záznamu reagovala. 
U: Děcka, ale já jsem slyšela, že vám to paní učitelka nelepila včera kvůli tomu, že polovina z vás neměla žákovské a dneska?

Ž1: Já jsem se snad poprvé zapomněl.

Ž2: Já ju mám.

U: „To je ted' už jako běžný trend? Ty už to máš zohlé, ale já nebudu zjišt'ovat, kolikrát za rok si zapomněl žákovskou nebo nezapomněl žákovskou. Ale žákovská je na to, abychom my prostřednictvím něčeho sdělovali výsledky vašich...vašeho vzdělávání nebo i nějaké vzkazy rodičům, já ted' nebudu telefonovat, abych někomu povykládala, jak se dostane k výsledkưm svého dítěte." (Adéla, 7. ročník, matematika)

Výchovný apel může být odrazem vnímané potřeby učitele věnovat se jednomu ze žáků, zároveň tak učitel prezentuje i své postoje ke vzdělávání. V předchozí části věnované instrukčnímu žánru jsem už zmiňovala volbu učitele Martina věnovat se žákům 6. ročníku, kteří přechodem na 2. stupeň základní škole vstřebávají také potřebu odlišného přístupu k učení, potřebu větší samostatnosti, se kterou budou učitelé na tomto stupni vzdělávání počítat.

U: „Jako já to umím a vím, protože zvlášt' u některých, ale jako líp než tady se už mít nebudeš ve školách, jo ted' neříkám na téhle základní škole, i když to tak je, ale myslím tím jako celkově to školství jako takové, až půjdeš o kousek vejš, tak se tam nebudou s tebou tak jako, tak, aby tě posouvali, tlačili, něco vysvětlovali třikrát, čtyřikrát, tam už to budou očekávat od tebe nějaké standardy, nějaké pravidla, nějaké, nějakou vůli, abys tu školu nějakým způsobem udělal, zjistit ty vědomosti a tady to zatím není a spíš mám pocit, že začínáš na to kašlat na učení, takže začni přemýšlet nad tím, jestli to někde nejde změnit." (Martin, fyzika, 6. ročník)

Výskyt extenzivních promluv patřících k tomuto žánru je pochopitelně ovlivněn př́ípadnou pozicí učitele jako tř́́dního, kdy role učitele rozšiřuje o další požadavky koordinování trrídy a očekávání školy i rodičů, že tuto roli učitel naplňuje a zvládá. Vzniká tak potřeba učitele vkládat výchovné promluvy, určené obvykle třídě jako celku, a učitelka Adéla ve „své“ 7. třídě tak ani nepřipouští žádnou diskuzi.

U: Eee děcka poslouchejte, ale množí se stížnosti na vaše chování, opět. Už to jak jste se chovali včera v hodině a matematice, jo? Tak jak...jak máte takové ty svoje vlny, tak opravdu včera hrůza, ale ty přestávky neexistují. To, co děláte... jak můžete diskutovat s vyučujícím o jeho pokynech? Arture, ty, ty neznáš školní řád?

Ž: Já jsem chtěl na záchod.

U: Na záchod měls čtvrt hodiny před tím. 
Ž: ...(nejde rozumět - něco ve smyslu, že se mu chtělo až potom v hodině)

U: Jo, ono se ti začalo chtít najednou. A to je divné, žes byl hodinu před tím. Já mám dole dozor, tak vidím, jak se pohybujete po chodbách. Školní rád je od toho, aby se dodržoval. A né, že ty si budeš zrovna jako usmyslet něco jiného, tak si budeš dělat, co chceš ty. Tak pojd'me na referáty. (Adéla, zeměpis, 7. ročník)

Mezi dvěma promluvami proběhla výměna mezi učitelem a žákem, který reagoval na otázku, jakou můžeme považovat za řečnickou. Učitelka totiž znalost školního řádu pochopitelně předpokládá. Neprojevuje ovšem zájem zjišt'ovat či diskutovat vzniklé problémy, poté, co sdělí vše, co sama chtěla říct, přepíná opět na téma výuky. Pro žáky je to jasný signál, že jakákoliv reakce se od nich dále neočekává.

Předchozí příklady z analyzovaných hodin se vztahovaly k subžánru výchovného upozornění, ovšem mimo rámec obsahu výuky nacházíme také sdělení, která se týkají jednodušší organizace třídy. Pro ilustraci uvádím následující příklad, ve kterém učitel Adam (jako tř́ídní učitel v dané 6. třídě) odkazuje mimo jiné na nedostatek času pro výuku, pokud musí podobné záležitosti řešit.

U: Tak...eee...co se týká, jak se mě ptal Honza, nejdříve teda udèlám pár tř́idnických věcí, doufám, že tím nezdržím pưlku hodiny...skř́ňn je samozřejmě od toho, abyste si tam dávali věci, ne ted' prosím vás...když tak po přestávce, Dominiku, sedni si normálně, eee, takže ty kufř́ky, tělocviky, výtvarku a podobně si tam klidně dávejte...nemusíte se mě ptát, jestli můžete, nebo nemůžete, ta skřín je tady postavená pro vaše věci, o ně tady jde. Za druhé taková třídnická věc je ta...že jsem vám včera ř́kal o obědech, eee, že si je máte odhlašovat. (Adam, český jazyk, 6. ročník)

Pro učitele Adama platí, že jeho sdělování v extenzivních promluvách je typické slovní vatou, nejistotou ve vyjadřování. Na jednu informaci se snadno nabaluje další, a to paradoxně tedy $\mathrm{v}$ situaci, kdy si sám uvědomuje, že má k dispozici jen omezený čas vyučovací hodiny. Zjednodušení jeho promluv, explicitnější formulace nebo častější forma otázek pro žáky by přitom mohla být cestou, jak si čas věnovaný organizačním záležitostem efektivně vynahradit.

\section{4}

\section{Reaktivita ve vztahu k okrajovým žánrům}

Podoby reaktivity v případě instrukčním, evaluačním a apelativním žánru nejsou tak různorodé jako u expozičního žánru. Roli hraje jistě i fakt, že se jedná o žánry, které uvádím jako méně četné v datovém souboru. 
Učitelova promluva patřící k instrukčnímu žánru se vyskytuje ve struktuře komunikace jako iniciace učitele. Přechod na instrukci patř́ k promyšleným krokům učitele, jenž si k danému tématu v učivu připravuje vždy jak výklad, tak i jeho procvičení či ověření. Instrukce je signálem ke změně práce a jasnou informací, že ted' tedy přichází moment zapojení žáků. Instrukční promluva je pak zakončená výzvou k práci či otázkou na žáky, která nevyvolá vstup žáka nad rámec vyžádané (případně absentující) odpovědi. $V$ datech se ukazuje, že výjimku tvoří pouze ty př́pady, kde se instrukce obaluje výpověd'mi vysvětlujícími jak nezbytné pro zvládnutí úkolu, tak i bonusovými informacemi. Právě ty byly klíčovým momentem pro vstup žáka do komunikace mimo očekávání učitele v promluvách expozičního žánru. Signalizují uvolnění managementu komunikace učitelem. A žáci tak „zapomínají“, že mluví především v okamžiku, kdy se to od nich žádá. Prolínání instrukce k individuální práci žáka a vysvětlování probíraného jevu v přírodopisu v následující ukázce vyvolá zájem žáka, jenž pokládá otázku, která ho právě napadla.

U: Sedmdesát devět začíná, osmdesát pokračuje, takže si napište střevlíkovití. Jak si budete kreslit toho svižníka, protože většina to nemá, tak musíš chvilečku počkat. Střevlíkovití, takže na rozdíl od těch zavalitých slunéček, ted' už tam nevidíme vůbec nic, jsou střevlíci spíše takoví atleti, mně prípomínají, protože běhají hodně, loví kořist, to znamená, že jsou dravci, pohybují se v noci a vy si nakreslíte jednoho z nich, nejlepší toho svižníka, protože o něm znáte pěknou písničku. Jenom abyste věděli, slunéčko kulaté, střevlíci spíše takoví jakoby běhaví brouci, uloví žížalu, takže docela velkou kořist, určitě uloví všechno menší housenky, co se v té půdě pohybují, můžete je nachytat na zahnívající maso, to se vám z celé zahrady slezou k té vaší návnadě. Ted' si pište, co rríkám, to stačí a pak si nakreslíte toho bud' svižníka, jestli se vám libí ten střevlík zlatolesklý víc tak už to nechám na vás. Střevlíkovití, protažené tělo, nekresli mi tu slunéčko, jo to musí být dlouhé, spíše podlouhlé, ne kulaté, protože kdybys ho měl takhle kulatý, nic nedoběhne, žádnou larvu. Když si vzpomenete, jak vypadají běžci, tak to je prostě dlouhé svalnaté rítící se někam. Proto chci svižníka, abyste si zazpívali: chvátám, chvátám, to jsou prostě střevlíci, tak je poznáte na první pohled. Nepoznáte, jestli je to kvapník, svižník, ale poznáte, že to patří do střevlíkovitých.

Ž: Paní učitelko...a proč je to zrovna střevlík, jak se přišlo na ten název, jestli od střeva jako?

U: Bratři Presselové v osmnáctém, devatenáctém století vymýšleli prostě slova, aby to byly české, některéjsou zvláštní, možná střevlík jako střela, ne jako střevo. Ty jsi tady u slunéčka, takže slunéčko si napíšeš dravé, kulaté, zahrady, mšice jo, to je to co chci od vás, abyste věděli. Kreslí se, no, hlavně, že to vím. Tady pěkně, dokážete takové krásné věci udělat. Tužkou to dokresli, at'si to uvědomíš, jo střevlíkovití. 
Primárním cílem učitele bylo předat žákům pokyny k samostatné práci. Ti jsou však zřejmě nastaveni na vnímání vysvětlovacích výpovědí učitele tak silně, že reagují v promluvě na přírodovědný pojem, nikoliv pokyn. Učitelka je navíc konfrontována se skutečností, že odpověd' nezná, jak si můžeme domýšlet z metakomunikačního klíče „možná“. Odpověd’ tak sice nerozvíjí, ale také neignoruje otázku. Tento signál je pro žáky velmi důležitý. Pokud by se v komunikačním jednání objevovaly podobné momenty častěji, vytvářela by podmínky pro reakce žáků napříč žánry extenzivních promluv.

Analyzovaná data promluv patřících k evaluačním a apelativním žánrům ukazují bohužel na případ, jaký jsem nazvala nulovou reaktivitou (viz kap. 8.4.4). Ze strany učitele jde o iniciaci, která je vyvolána spíše situačně, nikoliv jen na základě jednotlivé repliky žáka. U expozičního žánru se týkala komentáře učitele k samostatné práci žáka, který vnímali jen jako podkres a nevyvolal žádnou reakci, protože nebyla ani očekávána. Extenzivní promluvy učitele, které hodnotí žákovu práci nebo se v nich učitel vyjadřuje k chování žáků, by přitom měly vyvolat odezvu na jejich straně. Všechna sdělení učitele by se žáků měla přímo týkat, v apelu a hodnocení je však ještě zřetelnější, že učitel mluví skutečně pro ně a hlavně o nich. Proč tedy reakci v datech nenacházíme? Výzkum realizovaný Leeem (2008), který zahrnoval také zjišt'ování faktorů ovlivňujících reakce studentů na učitelovu zpětnou vazbu, ukázal odlišné výsledky než ty, které se v literatuře objevovaly. Vycházel na počátku z poznatku, že žáci preferují nepřímé hodnocení, které obsahuje spíše klíč k porozumění učivu tak, aby příště nechybovali, než přímé pojmenování chyby. Ale chtějí být každopádně aktivními partnery v hodnotícím procesu. K jeho zásadním zjištěním však patřila opačná tendence žáků. Vyjadřovali preference k učiteli jako hlavnímu aktéru hodnocení, sami si přáli spíše zastávat pasivní roli. Lee (ibid) vztahuje tento výsledek k dominantní, učitelem centrálně řízené komunikaci. Žáci si na ni přivyknou, snad je ani nenapadne, aby na hodnocení přímo reagovali. Dalším možným faktorem, o němž můžeme uvažovat, je předchozí negativní zkušenost. Žáci možná tuší, že diskuze se nepřipouští, sdělované informace raději nechtějí řešit, obzvlášt' v př́ípadě jejich nesouhlasu. Domnívám se, že tento důvod se může týkat především apelativního žánru. Třetí možností, která se specificky váže již k extenzivitě promluv, které zkoumáme, je nejasnost, na které ze sdělovaných informací vlastně může žák reagovat. I pro evaluační extenzivní promluvy totiž platí, že učitel žáky zahrne množstvím informací, s verbalizovanými myšlenkovými pochody učitele, ovšem bez podpory získat stanovisko žáka. 

9/

\section{JAK SE PROJEVUJE EXTENZIVITA V ŽÁNRECH PROMLUV UČITELE?}

Extenzivní promluvy učitele tak, jak jsem je vymezila, byly běžnou součástí všech zkoumaných vyučovacích hodin na 2. stupni základní školy. Vyskytovaly se tedy napříč různorodými vyučovanými předměty, ve všech ročnících, u všech šesti učitelů, jejichž promluvy jsem analyzovala.

Nejčastěji patřily extenzivní promluvy učitele k expozičnímu žánru. Souvisí to s potřebou učitele řídit komunikaci ve třídě také ve vztahu k probíranému tématu dané vyučovací hodiny. Rozhovory mezi ním a žáky slouží k orientaci v tom, k čemu je třeba se dále vyjadřovat - co zopakovat, vysvětlit, upřesnit, doplnit. To už však obstarává sám učitel. Ve zkoumaných hodinách jsem navíc zaznamenala vícekrát neverbálně i verbálně vyjádřenou kontrolu učitele nad vymezenými minutami jedné vyučovací hodiny. Už na začátku hodiny literatury přišla tak učitelka s informací, že „dneska toho máme strašně moc, protože jsme se dostali do 2. poloviny 20. století..... V poslední fázi výuky se žáci pravidelně dozvídali, že „Poslední, už toho moc nestihnem...nevím, jestli s tím vưbec budem začínat, ale...budem.“ nebo „Tak, děcka, napišme si jenom to, co stihneme.“ a „Britové se, Míšo, neboj, mám to propočítané do minuty, Britové se ubránili, poslední věta, a je to první německý neúspěch.". Zatímco v první fázi vyučovací hodiny se ještě objevuje otevření tématu učiva rozhovorem učitele s žáky, během hodiny vymezené minutami od zvonění ke zvonění přibývá právě extenzivních promluv učitele. Souvisí to jak s tím, že běžný postup učitele je zahájit výuku opakováním a prověřováním předchozího učiva sledem otázek, obvykle uzavřených s kognitivně nízkou náročností, kde je ale zároveň učitel ještě ochotný věnovat čas rozhovoru. Dále ale i s tím, že postupem času učitele „dohání“ čas a uvědomuje si, že pokud má téma hodiny stihnout, je potřeba komunikaci více řídit a odměřovat. 
Učitel v extenzivních promluvách, kdy je po delší čas jediným mluvčím ve třídě, musí udržet pozornost svých žákủ. Na rozdíl od instrukčního či evaluačního žánru nejsou promluvy patřící k expozičnímu žánru explicitně adresované žákům. Orientují se na prezentované téma. Pokud tak učiteli nepomáhá kupř́́kladu expresivita vyjadřování či humor, udržuje pozornost žáků vytvářením zdánlivé interakce. Do promluvy vkládá jejich oslovení, potvrzovací slovíčka (jo?), narážkami na související preference či potřeby žáků jim demonstruje, že je stále vnímá. Spíše než jako snahu o interakci se žáky lze ovšem tyto prvky vnímat jako součást strategie pro udržení kontroly nad tř́ídou. Učitelé se dopouští ve zkoumaných promluvách také určitých verbálních přešlapů, mezi stěžejními informacemi k výkladu či vysvětlení učiva se tak ukrývá ironie, zastrašování zkoušením, předjímání neúspěchu žáků.

Učitel často komunikuje žákům význam překládaného obsahu expoziční promluvy, lze najít případy, kdy využívá potenciál extenzivní promluvy k přemostění mezi vysvětlovanými jevy a situacemi v běžném životě. Umožňuje tak přijetí sdělovaného obsahu nad rámec pouhého zapamatování si poznatků potřebných pro školní úspěšnost. Informační bohatost takových promluv je značná, avšak podporující motivaci, učební proces žáků, aktivizující jejich zapojení do komunikace ve tř́dě. Žádná mince nemá však jen jednu stranu. V analyzovaných promluvách expozičního žánru tak poukazuji i na opačnou „strategii“ učitele, kdy jeho vyjádření působí demotivačně, samotný význam sdělení je vlastně popírán.

Většina extenzivních promluv učitele v mém datovém materiálu alespoň doprovází situace, kdy se učitel ujímá slova a přechází do extenzivní promluvy až poté, kdy proběhne rozhovor mezi ním a třídou či žákem. Jak to vypadá, když se učitel už ani nesnaží o iluzivní dialog (Šed’ová, 2009), ale zaměří se pouze na výklad, a nebýt toho, že se občas v pozadí ozve některý ze žáků, mohli bychom pouze z přepisu nebo zvukového záznamu získat dojem, že učitel je ve třídě sám, to nám dokládá ukázka z výuky dějepisu v 9. ročníku.

U: Ták, výborně. Takže tady vidíte, jakým způsobem dal Churchill na vědomí Hitlerovi, že už žádné ústupky nebudou. No, co asi bude následovat? K tomu, aby Hitler mohl provést invazi...(1s)

Ž: (v pozadí, téměř neslyšně) Bitva o Anglii.

U: Bude následovat bitva o Anglii, takže vynechejte si řádek, už toho moc nebude na psaní, nebojte se, bitvu o Anglii tu prosvištíme, ta trvala zhruba jen jedny prázdniny letní, takže to nebude žádná dlouhá doba. Nový rádek, nový nadpis a nazvem si to jednoduše bitva o Británii, nebo o Anglii, dáme si bitva o Anglii. (4s) (píše na tabuli) Pořád jsme v roce štyrycet a jedeme dál, takže máme za sebou červen, takže následují prázdniny a o prázdninách, tam někdy do srpna, do září bude probíhat 
bitva o Anglii. To se vám bude dobře pamatovat, bitva o Anglii, takže, tady na tom ne úplně kvalitním obrázku máme Churchilla uprostřed.

Ž: (téměř neslyšně) Já ho nevidím.

U: (ukazuje na promítnutou fotografii v prezentaci nad tabulí) Ukaž? Tady toho pána v klobouku to je on... ten, co máte v učebnici, tvář́i se pořád stejně. Tak, k té bitvě o Anglii. Napište si, že probíhala zhruba od... a dáme si to, ta nejdůležitější část probíhala od srpna tak dáme si to od srpna do září, to jsou trošku posunuté prázdniny, to jsou takové vysokoškolské prázdniny, od srpna do září devatenáct set čtyrycet, takže vidíte, že v tom roce devatenáct set štyrycet bylo docela živo. Od srpna do září devatenáct set čtyrycet, no tak k tomu, aby ten Hitler mohl provést invazi, tak je jasné, že ti Britové se budou bránit, tak je nejprve se pokusil napadnout ze vzduchu, což se nám líbí, když je to ostrovní země. Mimochodem když Hitler hrozil obsazení Československa tak hlavním argumentem, nebo tím, čím nejvíc vyhrožoval, že rozbombarduje Prahu, v tomto prípadě k tomu opravdu přistoupil, šak sami vite, že rozbombardoval Prahu, ale hrozilo se rozbombardovat mimo jiné Londýn. Tak, ale k tomu se ještě dostanem, máme tady před sebou další cizí slovo, dneska poslední a zase bude německé, takže zkuste oprášit svoji němčinu... (Jakub, 9. ročník, dějepis)

Stejnou komunikační strukturu má celá vyučovací hodina. Pouze ke konci je výklad už narušen netrpělivými žáky, kteří stejně jako učitel hlídají ubíhající čas, a v závěru mají přislíbeno dozvědět se známky z poslední písemné práce. $V$ rámci analyzovaného datového materiálu se sice jedná o extrémní případ, vyučovací hodinu naplněnou pouze extenzivními promluvami učitele, ale poukazuje na situaci ve tř́ídě, kdy učitel je bohužel jen poutavějším zprostředkovatelem než kupříkladu kniha.

Extenzivní promluva je často reaktivní promluvou. V souladu s běžnou strukturou výukové komunikace se jedná o promluvu, která reaguje na předchozí sdělení žáka. Nelze samozřejmě konstatovat, že by učitel byl jediným mluvčím ve třídě, žáci se ke slovu dostávají. U extenzivních promluv mě však v rámci reaktivity zajímalo především to, zda promluvy v jednotlivých žánrech umožňují vstup žáka do komunikace jinak než po přímé výzvě učitele ve formě otázky či pokynu. Nemám ovšem na mysli jakoukoliv promluvu žáka z hlediska obsahu. Provázanost replik vymezující reaktivitu znamená, že žák reaguje v logické, rozvíjející vazbě na obsah učitelova sdělení. Pro většinu žánrů v mém datovém materiálu platí, že taková situace nenastala. Výjimkou jsou promluvy popsané v kap. 8.4.3.1. Celkově tak převládá uzavřenost extenzivních promluv z hlediska možné interakce se žáky. Zjištění týkající se tohoto aspektu reaktivity shrnuje následující tabulka. 
Tab. 6 Reaktivita promluv se vstupem žáka do komunikace v jednotlivých žánrech

\begin{tabular}{|c|c|c|}
\hline žánr & $\begin{array}{l}\text { vstup žáka do komunikace nad } \\
\text { rámec př́mé výzvy učitele }\end{array}$ & kontext promluvy - přístup učitele \\
\hline \multirow{2}{*}{ expoziční } & ne & $\begin{array}{c}\text { Učitel jako zprostředkovatel potřebných } \\
\text { informací }\end{array}$ \\
\hline & ano & $\begin{array}{l}\text { Učitel jako zprostředkovatel } \\
\text { bonusových informací }\end{array}$ \\
\hline \multirow[b]{2}{*}{ instrukční } & ne & Učitel jako zadavatel úkolu \\
\hline & ano & $\begin{array}{c}\text { Učitel jako zprostředkovatel } \\
\text { bonusových informací souvisejících } \\
\text { s úkolem }\end{array}$ \\
\hline evaluační & ne & Učitel jako jediný posuzovatel žáka \\
\hline apelativní & ne & $\begin{array}{l}\text { Učitel jako manažer chodu třídy } \\
\text { a vychovatel }\end{array}$ \\
\hline
\end{tabular}

Narušení stereotypního modelu komunikace s učitelem jako iniciátorem a žákem jako vybraným komunikantem nabízí tedy jen extenzivní promluvy, u nichž žáci zřejmě vnímají sdělované nadstavbové informace jako možnost vstoupit do výukové komunikace. 0 těchto extenzivních promluvách můžeme uvažovat jako o příznakových z hlediska žádoucnosti. Samotná extenzivita zde nepůsobí jako komplikace či eventuální faktor působící proti rozvinutí dialogu mezi učitelem a žáky. Uvolnění atmosféry ve třídě prostřednictvím sdělování bonusových informací se však nemůže stát strategií, která by celkově způsobila zásadní změny směrem ke kvalitě komunikace ve školní třídě. 


\section{0/ \\ DISKUZE}

Informační bohatost jako zásadní kritérium vymezení extenzivní promluvy v řeči učitele se po analýze dat ukazuje být spíše informační přesyceností. Komplikace jako důsledek se projevují v neporozumění na straně žáků. Odpovídají pouze na poslední zaznamenanou část učitelovy promluvy, která však nemusí být nejdůležitější, znovu se dotazují na podstatu učitelovy výpovědi, a to především v expozičním žánru, ale také ve sdělovaných instrukcích. Zároveň se lze domnívat, že limitem pro zapojení žáků do komunikace jinak než pod taktovkou učitele nemusí být jen jeho dominantní řízení komunikace ve třídě. Pokud se žáci ztrácejí v promluvě učitele, na co pak mohou reagovat?

Cílem mého výzkumu bylo zjistit, jak fungují žánry extenzivních promluv učitele ve výukové komunikaci. Zjištění, že expoziční žánr je v hodinách nejvíce zastoupen, není nečekaným překvapením. Dosavadní výzkumy se rovněž zaměřují nejvíce na vysvětlování učitelem (Wittwer \& Renkl, 2008), zatímco k práci učitele s instrukčním žánrem doklady nenacházíme. Zajímavé ovšem je, jak často jsou žánry promíseny tak, že původní záměr učitele vysvětlit jev či pojem učiva se utápí v dalším cíli. Učitel tak do vysvětlení zahrne informace k významu znalosti pro úspěšnost v písemném prověření v následujícím týdnu a přidá ještě propojení s hodnocením minulých výkonů v souvisejícím učivu. A v případech, kdy se v celé promluvě expozičního žánru uchová sledování jednoho záměru učitele, můžeme se zamýšlet nad možnostmi jeho naplnění. V hodinách matematiky, fyziky či chemie jsem takto shodně s Geelanem (2013) identifikovala promluvy, které jsem přiřadila k subžánru komentář. Jejich kvalita je diskutabilní, protože přináší pouze rozsáhlý slovní doprovod k demonstrovaným výpočtům.

Vysvětlování je výhradní doménou učitele. Učitel přitom může zůstat dominantním manažerem výukové komunikace. Ovšem v rámci řízení je stále možné 
poskytovat prostor k vyjádření i dalším jedincům, s nimiž sdílí základní edukační cíle. A pokud nechce či nezvládá zapojit žáky do procesu předávání poznatků, může svá sdělení zkusit alespoň více štěpit tak, aby neobsahovala př́liš mnoho informací najednou. Tato strategie se totiž učiteli nakonec může vyplatit. Při poskytnutí času na reakci žáka a jejímu rozvinutí nebude muset nakonec tolik jevů a pojmů ještě znovu vysvětlovat.

Ostatní identifikované žánry extenzivních promluv se nevyskytují už v takové míře jako žánr expoziční. Instrukční žánr se navíc často prolíná s prvky vysvětlování či komentáře $\mathrm{k}$ danému tématu. Typickým jevem analyzovaných promluv je instrukční vata, tedy nabalování informací v promluvě, zmatečnost výpovědí. Učitelé mají tendenci vložit do instrukce vše, na co by se jinak žáci mohli zeptat, jejich otázkám se tedy snaží spíše předcházet.

Při čtení instrukce v transkribovaném materiálu (přičemž jde při porozumění o jednodušší proces než vnímání promluvy přímo ve vyučovací hodině, kde působí množství komunikačních šumů) se př́iliš často nabízí otázka, kterou bych jako žákyně v duchu vyslovila: „A co máme tedy vlastně dělat?“. Učitel neuvažuje nad tím, že by do instrukce mohli žáci vstupovat. Tedy že by kupříkladu po sdělení jádra požadované činnosti zbývající část instrukce prošel se žáky prostřednictvím návodných otázek. Získal by významné informace o porozumění žáků pokynům, o strategiích myšlení, pravděpodobně však i o jejich názoru na danou činnost, což může učitel vnímat jako jisté riziko. Pokud si učitel uvědomuje, že i na zadání činnosti se mohou žáci podílet, upouští od něj z dalších možných důvodů. Takový přístup by vyžadoval ochotu naslouchat otázkám žáků a udržet zároveň ve třídě pořádek. A důležitým faktorem je čas výuky, obzvlášț v předmětech s nižší dotací hodin. Učitelé obecně sdílejí názor, že množství požadovaných výstupů stanovené Rámcovým vzdělávacím programem pro ZŠ by se mělo redukovat (Jarníková \& Tupý, 2012). Cítí-li se zavázaní nastaveným objemem učiva, věnují více času expozičnímu žánru a mnohé informace raději sdělují sami, bez následného ověření porozumění žáky. Poskytnout další prostor ještě i rozvíjení instrukcí a riskovat přitom ztrátu kontroly nad pořádkem ve třídě se zdá být nereálný úkol.

Stejně tak se projevuje záměr vtěsnat do jedné promluvy vše důležité i v evaluačním žánru, především pokud přináší souhrnné hodnocení. Zpětná vazba je pro žáky nesporně důležitá, v návaznosti na ni by však měli dostat právě žáci možnost vstoupit do komunikace, argumentovat, diskutovat. Informační přesycenost extenzivní promluvy však překryje samotné jádro hodnocení, které v souladu se zjištěními Šed'ové a Švařrička (2010) nebývá vždy explicitně vyjádřené, ale existují případy zamlčeného hodnocení. Žáci pak nemohou ze zpětné vazby těžit pro porozumění kvalitě svého výkonu a učení. Specificky pro extenzivní promluvy bychom 
mohli uvažovat o hodnocení utlačeném, tedy s odkazem na množství informačních jednotek v promluvě.

Zkoumání reaktivity extenzivních promluv, tedy provázanosti s předchozími a následnými promluvami učitele či žáka ukázalo, že tyto promluvy jsou v mnoha případech reakcí učitele na odpověd' žáka, která není přesně taková, jakou učitel požadoval. Paradoxně pak působí především případy extenzivních promluv reagujících na správnou odpověd' žáka, ovšem vyjádřenou velmi stručně, někdy jediným slovem. Upřesnění, vysvětlení, shrnutí se tak ujímá opět učitel a žáci vyčkávají, jaký bude jeho další komunikační tah. Potenciál změny zaběhnuté struktury s žáky vystupujícími spíše v pasivní roli lze sledovat u extenzivních promluv, kde učitel obohacuje informace o bonusové příklady, propojuje základní zamýšlený obsah učiva se zajímavými aplikacemi poznatků v životě mimo školu. Tyto promluvy jsou stále obtížné z hlediska procesu porozumění sdělení žáky, protože se opět setkávají s informační nadměrností. Pokud však uvažujeme nad příznakovostí těchto promluv pojatou jako škála (Greenberg, 2005), nikoliv jen v binárních opozicích, můžeme konstatovat, že učitelovy extenzivní promluvy s bonusovou informací se pohybují na škále blíže k žádoucnosti.

\section{1}

\section{Limity výzkumu}

Datový materiál zahrnuje pouze vyučovací hodiny, kde učitel volí hromadnou organizační formu jako převládající. Pouze v pěti zaznamenaných hodinách se objevuje kratší úsek, kdy žáci pracují individuálně nebo ve dvojici, i tady ale učitel využívá změnu formy sice plánovaně, ale mechanicky, a nesnaží se využít její potenciál pro navození diskuze ve třídě. Práci žáků v těchto případech navíc učitel doprovází opět extenzivními promluvami - komentáři, které jsem popsala v kapitole o expozičních žánrech. Stále je tedy hlavním řídícím aktérem komunikace ve třídě. Výzkumný vzorek analyzovaný v tomto výzkumu pochopitelně nemůže vést k prohlášení, že by se jednalo o obecně preferovanou organizační formu. Lze se domnívat, že pro učitele pod „dozorem“ videokamery a pozorovatele ve třídě mohla frontální výuka představovat menší riziko, že neudrží chování žáků pod kontrolou. Zároveň beru však v úvahu, že pokud bych se při sběru dat zaměřila specificky na vyučovací hodiny s jiným uspořádáním ve třídě než frontálním, podoba komunikace včetně výskytu a charakteristik extenzivních promluv učitele by mohla vypadat odlišně a snad tedy s větší příležitostí pro reaktivitu umožňující komunikační aktivitu žáků.

Za limitující by mohl být považován i široce nastavený výzkumný vzorek z hlediska vyučovaných předmětů. K tomu, že vzorek nebudu zužovat na určité typy, 
např. př́rodovědné předměty, mě vedla sama data. Rozdíl ve výskytu extenzivních promluv se u prvních dvou učitelů neukazoval, neměla jsem tedy oporu pro případné rozhodnutí, kterým předmětům se primárně věnovat. Zjištění týkající se vlivu nadstavbových, bonusových informací na vstup žáka do komunikace se rovněž vážou jak k výuce českého jazyka, tak i př́rodovědy.

Analýza žánrů extenzivních promluv nabídla pohled na prozatím méně zkoumaný jev výukové komunikace. Některé otázky zůstávají však nezodpovězené, nastavená metodologie by musela být rozšiřrena o hlubší interview s učiteli s následnými dalšími pozorováními, př́ípadně zapojením pohledu žákủ. Pokládané otázky by se mohly týkat zjištování toho, jak přesně učitelé uvažují nad strategiemi vysvětlování, instrukcí a dalších žánrů. Prozatím z neformálních rozhovorů s učiteli vyplývá, že se necítí být těmi, kdo v hodinách mluví mnohem více než žáci.

Kniha se opírá o méně známé koncepty ve vztahu k současnému zkoumání výukové komunikace. Výhodou je nový pohled namísto opakování již probádaného, zároveň však nové pojetí přináší riziko související se zakotvením v odborné literatuře. Extenzivní promluvy a jejich žánry jsou takovým př́ípadem. Jejich funkčnost prověří další výzkum a diskuze s odborníky nejen v pedagogických vědách. 


\section{ZÁVĚR}

Z předešlých empirických studií máme již komplexní představu o tom, jak probíhá výuková komunikace na 2. stupni českých základních škol (Janík \& Miková, 2006; Šed’ová et al., 2012, 2016 aj.) a významným jevem je zvyšující se analýza záznamů reálné výuky. 0 problémech v komunikaci ve tř́ídě víme, že trpí pod zaběhnutou strukturací IRF, a to včetně př́ípadných modifikací prostřednictvím různorodých vnitřních prvků struktury, které ji alespoň částečně obohacují. Ovšem rámec struktury zůstává, iniciace patří především učiteli a žáci vnímají následně zpětnou vazbu jako prvek uzavírací a obvykle vyčkávají, s čím do komunikace vstoupí opět učitel. Víme také, že problémem komunikace ve třídě je menší zastoupení dialogického vyučování postaveného na jasných principech, kterých lze dosáhnout (Šed'ová et al., 2016), ovšem vyžaduje to značné úsilí na straně učitele, ale i žáků, pokud nastává tak zásadní proměna ve vzájemné komunikaci. Na základě této práce jsem také usilovala o doplnění dosavadních poznatků z reálných komunikačních situací ve třídě o pohled na extenzivní promluvy učitele. $V$ získaných datech jsou zastoupeny na různých pozicích ve struktuře výukové komunikace a jejich analýza ukazuje na některé př́ípady, jež podporují možné obměny v komunikačním scénáři, i když je celkově nález spíše dokladem upevňování verbální moci učitele ve tř́iě.

Nejen aktuální české, ale i zahraniční výzkumy v oblasti výukové komunikace se orientují na potřebu hledat a aplikovat dialogické vyučování. Ačkoliv nelze na příkladu šesti učitelů ze tři základních škol hovořit o extenzivitě učitelských promluv v rámci zobecnitelnosti, zdá se, že patří k charakteristikám výukové komunikace. Domnívám se, že nejen kupříkladu fenomén učitelových otázek, ale právě i zkoumaná extenzivita promluv ukazují na aspekty výukové komunikace, které by učitelé měli brát v úvahu při reflexi vlastního působení. 
Domnívám se, že tento aspekt předkládané práce má potenciál pro další výzkumné vykročení. Informační bohatost vyjádřená jednotkami informací byla kritériem pro určení extenzivních promluv učitele v celém objemu jeho řeči ve výukové komunikaci. Informační bohatost lze podrobněji dále prozkoumat s využitím kvantitativní metodologie a doplnit tak kupř́íkladu zjištění o žánrech extenzivních promluv učitele. 


\section{SEZNAM POUŽITÝCH ZDROJŮ}

Abbaszadeh, Z. (2013). Genre-Based Approach and Second Language Syllabus Design. Procedia - Social and Behavioral Sciences, 84, 1879-1884.

Alexander, R.J. (2006). Towards Dialogic Teaching ( $3^{\text {rd }}$ edn.) New York: Dialogos.

Alexander, R. (2008). Culture, Dialogue and Learning: Notes on an Emerging Pedagogy In N. Mercer and S. Hodgkinson (Eds.), Exploring Talk in School, (s. 91-114). London: Sage Publications.

Applebee, A. N., Langer, J. A., Nystrand, M., \& Gamoran, A. (2003). Discussion-based Approaches to Developing Understanding: Classroom Instruction and Student Performance in Middle and High School English. American Educational Research Journal. 40(3), 685-730.

Auer, S. (2014). Jazyková interakce. Praha: NLN, Nakladatelství Lidové noviny.

Batistella, E. L. (1990). Markedness: the evaluative superstructure of language. New york: Oxford University Press.

Bachtin, M. (1986). Speech genres \& other late essays. Trans. Vern W. McGee. Ed. by C. Emerson \& M. Holquist. Austin: University of Texas.

Bendl, S. (2011). Školní kázeň v teorii a praxi: učebnice pro studenty učitelství. Praha: Triton.

Bhatia, V. K. (2002). Applied genre analysis:a multi-perspective model. Ibérica, 4, 3-19.

Bloor, M., \& Wood, F. (2006). Keywords in Qualitative Methods. A Vocabulary of Research Concepts. Thousand Oaks: Sage Publications.

Bosák, C. (1974). Stimul a apel v dialogu. Slovo a slovesnost, 35(2), 96-98.

Boyd, M. P., \& Rubin, D. L. (2006). How Contingent Questioning Promotes Extended Student Talk: A Function of Display Questions. Journal of Literacy Research, 38(2), 141-169. 
Brekhus, W. A. (1998). Sociology of the Unmarked. Redirecting our Focus. Sociological Theory, 16(1), 34-51.

Burns, Ch., \& Myhill, D. (2004). Interactive or inactive? A consideration of the nature of interaction in whole class teaching. Cambridge Journal of Education, $34(1), 35-50$.

Cangelosi, J. S. (2006). Strategie řízení třídy: jak získat a udržet spolupráci žáků při výuce. Praha: Portál.

Carlsen, W. S. (1993). Teacher knowledge and discourse control: Quantitative evidence from novice biology teacher's classroom. Journal of Research in Science Teaching, 30(5), 471-481.

Carstens, A. (2010). Analysing genre revitised, s. 227-239. Retrived from: https:// pure.au.dk/ws/files/9993/H19_20.pdf.

Cazden, C. B. (2001). Classroom Discourse. The Language of Teaching and Learning. Portsmouth: Heinemann, NH.

Creswell, J. W. (2007) Qualitative Inquiry and Research Design. Choosing among Five Approaches. Thousand Oaks: Sage Publications.

Cullen, R. (1998). Teacher Talk and the Classroom Context. ELT Journal, 52(3), 179-187.

Čech, R., \& Kubát, M. (2017). Slovní bohatství textu. In S. Karlík, M. Nekula, \& J. Pleskalová (eds.), CzechEncy - Nový encyklopedický slovník češtiny. Retrieved from: https://www.czechency.org/.

Čechová, M. (2005). Příznakovost systémová a situačně-kontextová. Naše řeč, $88(1), 9-17$.

Davies, M. J. (2011). Increasing students'L2 usage: An analysis of teacher talk time and student talk time. University of Birgmingham. Retrieved from: https://www. birmingham.ac.uk/Documents/college-artslaw/cels/essays/languageteaching/ Daviesessay1TTTessaybank.pdf.

Denzin, N. K., \& Lincoln, Y. S. (c2005). The SAGE handbook of qualitative research ( $3^{\text {rd }}$ ed.). Thousand Oaks: Sage Publications.

DeVito, J. A. (2008). Základy mezilidské komunikace: 6. vydání. Praha: Grada.

Dontcheva-Navrátilová, O. (2017). Analysing Genre: The Colony Text of UNESCO

Resolutions. Spisy Pedagogické fakulty Masarykovy univerzity, sv. 134. Brno: Masarykova univerzita.

Edwards, A. D., \& Furlong, V. J. (1978). The Language of Teaching. London: Heinemann.

Emmer, E. T. (2001). Classroom Management: A Critical Part of Educational Psychology, With Implications for Teacher Education. Educational Psychologist, 36(2), 103-112.

Fassett, D. L., \& Warren, J. T. (Eds.) (2010). The SAGE Handbook of Communication and Instruction. Los Angeles: Sage. 
Fisher, R., \& Larkin, S. (2008). Pedagogy or Ideological Struggle? An Examination of Pupils' and Teachers' Expectations for Talk in the Classroom. Language and Education, 22(1), 1-16.

Frankel, K. K. (2013). Revitising the Role of Explicit Genre Instruction in the Classroom. Journal of Education, 123(1) 17-30.

Gavora, P. (1988). Pedagogická komunikácia v základnej škole. Bratislava: Veda.

Gavora, P. (2005). Učitel a žáci v komunikaci. Brno: Paido.

Geelan, D. (2013). Teacher Explanation of Physics Concepts: a Video Study. Res Sci Educ, 43, 1751-1762.

Greenberg, J. H. (2005). Language Universals: With Special Reference to Feature Hierarchies. Berin: DeGruyter.

Gulová, L., \& Šíp, R. (2013). Výzkumné metody v pedagogické praxi. Praha: Grada.

Halliday, M. A. K. (1975). Learning how to mean: Explorations in the development of language. London: Edward Arnold.

Hammersley, M., \& Atkinson, S. (2007). Etnography: Principles in Practice. London: Routledge.

Haspelmath, M. (2006). Against markedness (and what to replace it with). J. Linguistics, 42, 25-70.

Hejna, B. (2010). Informační termodynamika I. Rovnovážná termodynamika přenosu informace. Praha: Vydavatelství VŠcHT Praha.

Hoffmannová, J. (1996). Fatická funkce jazyka, konverzace a její žánry. Slovo a slovesnost, 57(3), 191-205.

Hoffmannová, J. (2012). Promluva. In Nový encyklopedický slovník češtiny. Retrieved from: https://www.czechency.org/slovnik/PROMLUVA.

Hoffmannová, J., Homoláč, J., Chvalovská, E., Jílková, L., Kaderka, P., Mareš, P., \& Mrázková, K. (2016). Stylistika mluvené a psané češtiny. Praha: Academia.

Höflerová, E. (2003). Školský dialog a jeho vliv na rozvoj řeči dětí. Ostrava: Ostravská univerzita v Ostravě.

Homoláč, J., \& Mrázková, K. (2014). K stylistickému hodnocení jazykových prostředků, zvláště lexikálních. Slovo a slovesnost, 75, 3-38.

Hradilová, D. (2015). Funkční aspekty lexikální expresivity v současné češtině. Olomouc: US.

Hurt, H. T., Scott, M. D., \& McCroskey, J. C. (1978). Communication in the Classroom. Reading, MA: Addison-Wesley.

Chi, MTH. (2009) Active-constructive-interactive: A conceptual framework for differentiating learning activities. Top Cogn Sci, 1, 73-105.

Chin, Ch. (2006). Classroom Interaction in Science: Teacher questionnig nad feedback to students' responses. International Journal of Scienece Education, 28(11), 1315-1346. 
Chromý, J. (2008). K článku Jany Valdrové „Žena a vědec? To mi nejde dohromady.“ Naše řeč, 91(4),197-200.

Jamshed, S. (2014). Qualitative research method-interviewing and observation. J Basic Clin Pharm, 5(4), 87-88.

Janík, T. \& Miková, M. (2006). Videostudie: výzkum výuky založený na analýze videozáznamu. Brno: Paido.

Janíková, M. (2009). Interakce a komunikace ve výuce: výzkumné oblasti, přístupy a metody. In M. Janíková et al. Výzkum výuky: tematické oblasti, výzkumné přístupy a metody. Brno: Paido.

Janíková, M. (2011). Interakce a komunikace učitelů tělesné výchovy. Brno: Paido. Jarníková, J., \& Tupý, J. (2012). Co chtějí učitelé měnit v osnovách. Vzdělávání. Čtvrtletník Národního ústavu pro vzdělávání, 1, 6-8.

Johnstone, B. \& Marcellino, W. (2010). Dell Hymes and the Etnography of Communication. Retrieved from: http://repository.cmu.edu/cgi/viewcontent.cgi?artic$\underline{\mathrm{le}=1013 \& \text { context=english. }}$.

Lee, I. (2008). Student reactions to teacher feedback in two Hong Kong secondary classrooms. Journal of Second Language Writing, 17, 144-164.

Lehesvuori, S. (2013). Towards Dialogic Teaching in Science. Challenging Classroom Realities through Teacher Education. Jyväskylä: Studies in Education, Psychology and Social Research.

Leinhardt, G. (2001). Instructional explanations: A commonplace for teaching and location for contrast. In V.Richardson (Ed.), Handbook of research on teaching (s. 333-357). Washington, DC: American Educational Research Association.

Lemke, J. L. (1990). Talking Science. Language, learning and values. Norwood, NJ: Ablex. Lyle, S. (2008). Dialogic Teaching: Discussing Theoretical Contexts and Reviewing Evidence from Classroom Practice. Language and Education, 22(3), 222-240.

Ma Xiaou (2006). Teacher Talk and EFL in University Classrooms. (Dissertation Thesis). Chongqing Normal University \& Yangtze Normal University, China.

Mareš, J. (2009). Posledních dvacet let výzkumů pedagogické interakce a komunikace v ČR (1989-2009). In Doležalová, J. et al. (Eds.) Pedagogická komunikace v didaktických, sociálních a filozofických souvislostech. Hradec Králové: Gaudeamus.

Mareš, J. (2013) Nevhodné chování učitelů k žákům a studentům. Studia Paedagogica, $18(1), 8-36$.

Mareš, J. (2016). Zkoumání procesů a struktur ve výukové komunikaci: historie a současnost. Pedagogika, 66(3), 250-289.

Mareš, J., \& Křivohlavý, J. (1995). Komunikace ve škole. Brno: Masarykova univerzita. McCroskey, J. C., \& Richmond, V. S. (1982). Power in the Classroom I. Teacher and Student Perceptions. Educational Resources. Information Center (ERIC). Retrieved from: http://www.jamescmccroskey.com/publications/112.pdf. 
McCroskey, J. C., Richmond, V. S., \& McCroskey, L. L. (2005). An Introduction to Communication in the Classroom. The Role of Communication in Teaching and Training. Pearson.

Mehan, H. (1979). What time is it, Denis? Asking known information questions in classroom discourse. Theory into Practice, 18(4), 85-103.

Mejía, A., \& Molina, A. (2007). Are we promoting critical autonomous thinking? A discussion on conversational genres and whether they can help us answer this question. Cambridge Journal of Education, 37(3), 409-426.

Mercer, N. (2002). Developing dialogues. In Wells, G., Claxton, G. (Eds.) Learning for life in the C21st: Sociocultural perspectives on the future of education. Oxford: Blackwell.

Mercer, N. (2003). The educational value of dialogic talk in whole-class dialogue. In New Perspectives on Spoken English in the Classroom. London: The Qualifications and Curriculum Authority.

Mercer, N. (2010). The analysis of classroom talk: Methods and methodologies. British Journal of Psychology, 80, 1-14.

Mercer, N., \& Dawes, L. (2014). The study of talk between teachers and students, from the 1970s until the 2010s. Oxford Review of Education, 40(4), 430-445.

Miles, M. B., Huberman, A. M., \& Saldaña, J. (2014). Qualitative data analysis: a methods sourcebook ( $3^{\text {th }} e$ d.). Thousand Oaks: SAGE Publications.

Mistrík, J. (1975). Žánre vecnej literatury. Bratislava: Slovenské pedagogické nakladatel'stvo.

Molinari, L., \& Mameli, C. (2015). Triadické interakce ve výukové komunikaci. Studia Paedagogica, 20(3), 7-19.

Mortimer, E. F., \& Scott, S. H. (2003). Meaning making in secondary science classroom. Maidenhead, UK: Open University Press.

Myers, S. A. (2010). Philosophical and Methodological Foundations. In D. L. Fassett,

\& J. T. Warren (Eds.). The Sage Handbook of Communication and Instruction (s. 149-180). Los Angeles: SAGE.

Myhill, D. (2006). Talk, talk, talk: teaching and learning in whole class discourse. Research Papers in Education, 21(1) 19-41.

Nelešovská, A. (2005). Pedagogická komunikace v teorii a praxi. Praha: Grada.

Newby, S. (2014). Research methods for education (Second edition). London: Routledge, Taylor \& Francis Grous.

Nystrand, M. (1997). Opening dialogue: Understanding the dynamics of language and learning in the English classroom. New York: Teachers College Press.

Nystrand, M, L., Wu, L., \& Gamoran, A. (2001). Questions in Time: Investigating the Structure and Dynamics of Unfolding Classroom Discourse. Albany: National Research Center on English Learning \& Achieveme nt. 
Patton, M. Q. (2002) Qualitative Research \& Evaluation methods. Thousands Oaks: Sage Publications.

Pimentel, D. S., \& McNeill, K. L. (2013). Conducting Talk in Secondary Science Classrooms: Investigating Instructional Moves and Teachers' Beliefs. Science Education, 97(3), 367-394.

Plax, T. G., Kearney, p., McCroskey, J. C., \& Richmond, V. P. (1986). Power in the Classroom VI: Verbal Control Strategies, Nonverbal Immediacy and Affective Learning. Retrieved from http://www.jamescmccroskey.com/publications/133.pdf. Průcha, J. (2002). Pedagogika a komplexnost vědeckého poznání. Pedagogika, 52(2), 127-129.

Průcha. J. (2015). Přehled pedagogiky: úvod do studia oboru. Praha: Portál.

Rampton, B., Maybin, J., \& Roberts, C. (2014). Methodological foundations in linguistic ethnography. Working Papers in Urban Language and Literacies. Paper 25. Retrieved from: http://www.academia.edu/6155510/WP125 Rampton Maybin and Roberts 2014. Methodological foundations in linguistic ethnography. Richards, L. (2009). Handling Qualitative Data. A practical Guide. London: Sage Publications.

Roelle, J., Műller, C., Roelle, D., \& Berthold, K. (2015). Learning from Instructional Explanations: Effects of Prompts Based on the Active-Constructive-Interactive Framework. PLoS ONE, 10(4), 1-28.

Rymes, B. (2009). Classroom Discourse Analysis. A tool for Critical Reflection. New Jersey: Hampton Press.

Samuhelová, M. (1988). Štruktúry v pedagogickej komunikácii. In P. Gavora a kol. Pedagogická komunikácia v základnej škole (s. 55-73). Bratislava: Veda.

Scott, S. H. (1998) Teacher Talk and Meaning Making in Science Classrooms: A Vygotskian Analysis and Review. Studies in Science Education, 32, 45-80.

Scott, S. H., Mortimer, E. F., \& Aguiar, O. G. (2006) The Tension Between Authoritative and Dialogic Discourse: A Fundamental Characteristics of Meaning Making Interactions in High School Science Lessons. Wiley Periodicals, Inc. 605-632.

Shannon, C. E. (1948). A mathematical Theory of Communication. The Bell System. Technical Journal, 27, 379-423.

Sharpe, T. (2008). How can teacher talk support learning? Linguistics and Education, 19, 132-148.

Simonds, J. Ch., \& Cooper, S. J. (2014). Communication for the Classroom Teacher. Harlow: Essex.

Sluková, S. Z. (2007). Komunikace informací. Praha: UK v Praze.

Soter, A., Wilkinson, I., Murphy, K. P., Rudge, L., Reninger, K., \& Edwards, M. (2008). What the discourse tells us: Talk and indicators of high-level comprehension. International Journal of Educational Research, 47, 372-391. 
Strauss, A. L., \& Corbin, J. M. (1999). Základy kvalitativního výzkumu: postupy a techniky metody zakotvené teorie. Boskovice: Albert.

Světlá, J. (2003). K typologickým rozdílům mezi texty informativními a apelativními. Slovo a Slovesnost, 54(2), 88-106.

Svobodová. J. (2000). Jazyková specifika školské komunikace a výuka mateřštiny. Ostrava: Ostravská univerzita v Ostravě.

Syslová, Z., \& Hornáčková, V. (2014). Kvalita reflexe v profesním myšlení učitelek mateřských škol. Pedagogická orientace, 24(4), 535-561.

Šalamounová, Z. (2015). Socializace do školního jazyka. Brno: Filozofická fakulta, Masarykova univerzita.

Šebesta, K. (2016). Aplikovaná lingvistika vs. lingvistika v aplikaci aneb S kým/ čím se vlastně polemizuje? Studie z aplikované lingvistiky, 1, 121-130.

Šed’ová, K. (2009). Co víme o výukovém dialogu? Studia Paedagogica, 14(2), 11-28.

Šed’ová, K., \& Švaříček, R. (2010). Zamlčené hodnocení: zpětná vazba ve výukové komunikaci. Studia Paedagogica, 15(2), 61-86.

Šed’ová, K., Švaříček, R. \& Šalamounová, Z. (2012). Komunikace ve školní třídě. Praha: Portál.

Šed’ová, K., Švař́íček, R., Sedláček, M. \& Šlamounová, Z. (2014). On the Way to Dialogic Teaching: Action Research as a Means to Change Classroom Discourse. Studia Paedagogica, 19(4), 9-43.

Šed’ová, K., Švaříček, R., Sedláček, M. \& Šalamounová, Z. (2016). Jak se učitelé učí. Cestou profesního rozvoje k dialogickému vyučování. Brno: Masarykova univerzita. Šed’ová, K., Sedláček, M., Švaříček, R., Majcík, M., Navrátilová, J., Drexlerová, A., Kychler, J., \& Šalamounová, Z. (2019). Do those who talk more learn more? The relationship between studentclassroom talk and student achievement. Learning and Instruction, 63, 1-11.

Šlédrová, J. (1992). Studium komunikace z hlediska potřeb pedagogiky. Slovo a slovesnost, 53(2), 129-138.

Švaříček, R. (2011). Funkce učitelských otázek ve výukové komunikaci na druhém stupni základní školy. Studia Paedagogica, 16(1), 9-46.

Švaříček, R., \& Šed'ová, K. (2007). Kvalitativní výzkum v pedagogických vědách. Praha: Portál.

Thinking Together. (C) 2017 Thinking Together, Faculty of Education, University of Cambridge 184 Hills Road Cambridge CB2 8PQ, UK. Retrieved from: https:// thinkingtogether.educ.cam.ac.uk/about/.

Thompson, P. (2008). Learning Through Extended Talk. Language and Education, 22(3), 241-256.

Tůma, F. (2014). Dialogism and classroom interaction in English language teaching: A review of Czech research. Pedagogická orientace, 24(6), 878-902. 
Vávrová, S., \& Gavora, P. (2014). Analýza komunikace ohniskové skupiny ve výchovném ústavu. Studia Paedagogica, 19(2), 105-121.

Viiri, J., \& Saari, H. (2006). Teacher Talk Patterns in Science Lessons: Use in Teacher Education. Journal of Science Teacher Education, 17, 347-365.

Vybíral, Z. (2005). Psychologie komunikace. Praha: Portál.

Watzlawick, S., Bavelas, J. B., \& Jackson, D. D. (2011). Pragmatika lidské komunikace: interakční vzorce, patologie a paradoxy (2., rev. vyd., 1. v Newton Books). Brno: Newton Books.

Wells, G. (2006). Monologic and Dialogic Discourses as Mediators of Education. Research in the Teaching of English, 41(2), 168-175.

Wittwer, J., \& Renkl, A. (2008) Why Instuctional Explanations Often Do Not Work: A Framework for Understanding the Effectiveness of Instructional Explanations. Educational Psychologist, 43(1), 49-64.

Wrong, D. H. (2002). Power: its forms, bases and uses. London: Transaction Publishers. Wubbels, T., \& Levy, J. (Eds.) (2005). Do You Know What You Look Like? Interpersonal Relationships in Education. Bristol: Taylor Francis.

Wubbels, T., \& Brekelmans, M. (2005). Two decades on teacher-student relationships in class. International Journal of Educational Research, 43, 6-24.

Yates, J., \& Orlikowski, J. W. (1992). Genres of organizational communication. Academy of Management Review, 17(2), 299-325.

Young, R. (1992) Critical Theory and Classroom Talk. The Language and Education Library. Clevedon: Longdunn Press Ltd. 


\section{RESUMÉ}

Učitel ve vzájemné komunikaci s žáky v prostředí školní třídy je ústřední postavou této knihy. Zaměřuji se přitom na jeho verbální řeč, zajímají mě promluvy, které charakterizuji jako extenzivní, zkoumám jejich žánry. Extenzivita učitelových promluv je tématem, jakému se prozatím český ani zahraniční výzkum zcela nevěnoval. Předchozí, především zahraniční, studie se orientují na extenzivitu v řeči žáků jako na cílový, žádoucí jev ukazující proměnu rozložení komunikace směrem $\mathrm{k}$ aktivitě žáků. Jednotlivé kapitoly jsou provázány extenzivitou jako výchozím teoretickým konceptem zasazeným do specifik výukové komunikace s učitelem jako dominantním komunikátorem a nálezy v datech, které se opírají o analyzované extenzivní promluvy učitele ve výuce na 2. stupni základní školy. Extenzivní promluva je segment řeči, který se vyznačuje délkou nad rámec běžného rozsahu u daného mluvčího, v tomto případě tedy učitele, a informační bohatostí, která se rovněž vymyká očekávání příjemce v situačním kontextu. Nadměrnost informací znamená vyšší kognitivní náročnost sdělení, ovšem pouze ve smyslu možností pro porozumění textu sdělení žáky, nikoliv jako podpůrný prostředek pro rozvoj jejich myšlení. V extenzivní promluvě lze identifikovat její funkci, která určuje její zařazení ke konkrétnímu žánru. Žánr je pojmenováním pro typ promluv, které mají shodné prvky vnitřní i vnější struktury a jsou identifikovatelné př́ijemcem promluvy na základě rozpoznání komunikační funkce žánru. Výzkum využívá kvalitativní metodologie. Cílem výzkumu je zjistit, jak fungují žánry extenzivních promluv učitele ve výukové komunikaci. Sběr dat je primárně založen na participačním pozorování s využitím videozáznamů výuky šesti učitelů na základní škole. Datový soubor sestává z celkem 24 vyučovacích hodin přírodovědných i humanitně orientovaných předmětů v 6. až 9. třídě 2 . stupně na třech různých základních školách. Celkově byly identifikovány 4 hlavní žánry extenzivních promluv učitele 
ve výukové komunikaci - expoziční, instrukční, evaluační a apelativní žánr. Nejčastěji se v datech vyskytoval expoziční žánr, což je svázáno s tím, že učitel má stále potřebu řídit komunikaci ve tř́dě. Rozhovory mezi ním a žáky slouží k orientaci $\mathrm{v}$ tom, $\mathrm{k}$ čemu je třeba se dále vyjadřovat - co zopakovat, vysvětlit, upřesnit, doplnit. Další žánry se v datovém materiálu nevyskytovaly v takovém rozsahu jako primární, expoziční žánr. Učitel často komunikuje žákům význam překládaného obsahu expoziční promluvy, lze najít případy, kdy využívá potenciál extenzivní promluvy k přemostění mezi vysvětlovanými jevy a situacemi v běžném životě. Umožňuje tak přijetí sdělovaného obsahu nad rámec pouhého zapamatování si poznatků potřebných pro školní úspěšnost. V analyzovaných promluvách expozičního žánru tak poukazuji i na opačnou „strategii“ učitele, kdy jeho vyjádření působí demotivačně, samotný význam sdělení je vlastně popírán. Extenzivní promluva je často reaktivní promluvou, která často reaguje na předchozí sdělení žáka. U extenzivních promluv mě však v rámci reaktivity zajímalo především to, zda promluvy v jednotlivých žánrech umožňují vstup žáka do komunikace jinak než po př́mé výzvě učitele ve formě otázky či pokynu. Pro většinu žánrů v mém datovém materiálu platí, že taková situace nenastala. Výjimkou jsou již zmíněné promluvy přinášející žákům bonusové informace nad rámec běžného učiva předávaného učitelem. 


\section{SUMMARY}

The teacher as a main communicator in the classroom takes central stage in this book. The research focuses on teacher talk with a special interest in exploring extensive teacher talk and its genres. The extensiveness of teacher talk is a topic that has not been fully pursued by Czech or foreign research so far. In general, previous research has been oriented on students' learning through extended talk as a target, desirable phenomenon in the classroom communication with the aim to change the proportion of communication between teacher and student towards students' activity. The chapters are connected with extensiveness as initial theoretical concept embedded in the specifics of classroom communication with teacher as a dominant communicator, and consequently in the findings in data that are based on analyzed extensive teacher talk in the lower secondary school classes. Extensive teacher talk is characterized by a length beyond the normal range and information richness that also outweighs the recipient's expectations in a situation context. Excessive information means a higher cognitive intensity of the message, but only in terms of reduced possibilities for students' to understand the text, not as a supportive tool for the development of their thinking. Teacher extensive talk can be identified by its function (or functions) that determine a particular genre. The genre can be defined as a type of talk that has the same inner and outer structure elements, so the recipient of the talk is able to recognize the communication function of the genre. The research is based on qualitative methodology. The aim of the research is to find out how the genres of extensive teacher talk function in classroom communication. The main source of data were participant observation and video recordings of six elementary school teachers' lessons. In total, there were 24 lessons of science, language and history lessons of 6 th to $9^{\text {th }}$ grade at three lower secondary schools in Czech Republic. Four genres of analyzed extensive 
teacher talk were identified - expositional genre, instructional genre, evaluative genre and appealing genre. Expositional genre of extensive teacher talk appeared the most frequently. It is related to repeated teacher's need to manage classroom communication. The dialogue between teacher and students serve to focus on what needs to be said by a teacher - what to repeat, explain, refine, supplement. The other identified genres of extended talk do not appear to the same extent as the primary genre of exposition. The teacher often communicates the meaning of content in extensive talk to the students. There can be found examples of extensive talk using potential to make a bridge between the phenomena explained and the situations in students' everyday life. This allows the acceptance of content to be communicated beyond mere knowledge memorization needed for their school success. The opposite teacher strategy is found in some teacher extensive talks, when teacher's expression is demotivating the students and the very meaning of information is actually denied. Extensive talk is often a reactive kind of talk as teacher extensive talk often responds to the student's previous reply in communication. However, in the context of extensive talk, the partial aim of the research in this thesis is to examine if the identified genres of extensive talk allow students to enter the communication in another way than just after the teacher's direct request in the form of a question or instruction. In most of the cases, this turn in communication structure is not observed. Exceptions are found in the above-mentioned talks giving students a kind of bonus information in the lessons. 



\section{Univerzita Tomáše Bati \\ Fakulta humanitních studií}

FAKULTA HUMANITNICH STUDIII / EDICE PEDAGOGIKA

Název: Žánry extenzivní řeči učitele ve výukové komunikaci

Autor: PhDr. Hana Navrátilová, Ph.D.

Fotografie na obálce: Max Fischer, pexels.com

Vydavatel: Univerzita Tomáše Bati ve Zlíně, www.nakladatelstvi.utb.cz

Pořadí vydání: První

Rok vydání: 2021

Vydáno elektronicky

ISBN 978-80-7678-052-1 

